\title{
Archaeological Testing at 41BP678, Bastrop County, Texas
}

Antonia L. Figueroa

Center for Archeological Research, University of Texas at San Antonio

Follow this and additional works at: https://scholarworks.sfasu.edu/ita

Part of the American Material Culture Commons, Archaeological Anthropology Commons, Environmental Studies Commons, Other American Studies Commons, Other Arts and Humanities Commons, Other History of Art, Architecture, and Archaeology Commons, and the United States History Commons

Tell us how this article helped you.

This Article is brought to you for free and open access by the Center for Regional Heritage Research at SFA ScholarWorks. It has been accepted for inclusion in Index of Texas Archaeology: Open Access Gray Literature from the Lone Star State by an authorized editor of SFA ScholarWorks. For more information, please contact cdsscholarworks@sfasu.edu. 


\section{Archaeological Testing at 41BP678, Bastrop County, Texas}

Creative Commons License

(c) (i) (8)

This work is licensed under a Creative Commons Attribution-NonCommercial 4.0 International License 


\section{ARChAEOLOGicAl TeSting at 41 BP678,}

\section{BASTROP COUNTY, TEXAS}

$B Y$

ANTONIA L. FIGUEROA

WITH A CONTRIBUTION BY

STEVE A. TOMKA

KRISTI M. ULRICH

PRINCIPAL INVESTIGATOR

TeXas ANTIQUities Permit No. 4117

PREPARED FOR

THE CITY OF BASTROP

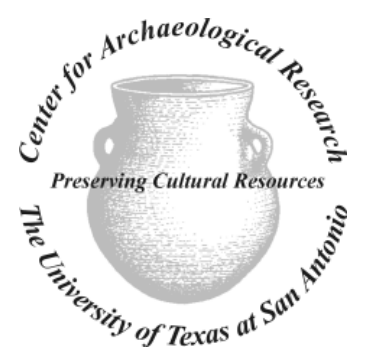

(C) 2006

CENTER for ARCHAEOlogical Research THE UNIVERSITY OF TEXAS AT SAN ANTONIO ARCHAEOlogical Report, No. 364 
A LiSt of publications offered by the Center for ARChaeological Research is aVAilable. Call (2 10) 458-4378; WRite to the Center for Archaeological Research, The University of Texas at San Antonio, One UTSA Circle, San Antonio, TEXAS 78249-1644; E-MAIL TO CAR@UTSA.EDU; OR VISIT CAR'S WEB SITE AT HTTP://CAR.UTSA.EDU. 


\section{Abstract}

During the spring of 2006 (April 27 through May 4, 2006), the Center for Archaeological Research (CAR) at The University of Texas at San Antonio conducted testing at 41BP678, a site formally listed as a State Archaeological Landmark. Site 41BP678 is located in Bastrop County at the confluence of the Colorado River and Spring Branch Creek, one of its tributaries. The site is on land that is the proposed location for the City of Bastrop Wastewater Treatment Plant. The installation of outflow pipes and the excavation of a 500-foot deep water well and associated utilities installations will impact the central and eastern portions of 41BP678. The testing was conducted under Texas Antiquities Permit No. 4117, with Kristi M. Ulrich serving as Principal Investigator and Antonia L. Figueroa serving as the Project Archaeologist. The testing involved mechanical auger borings, backhoe trenching and the hand-excavation of a limited number of test units.

Testing confirmed that 41BP678 is a multi-component site, with a Late Prehistoric presence in the upper $40 \mathrm{~cm}$ of the site, and a second component ( $40-80 \mathrm{~cm}$ below surface) of unknown temporal affiliation. Testing efforts failed to encounter features, and the low-density cultural materials consist primarily of lithic debitage and fire-cracked rock. A detailed debitage analysis of the samples from the two components suggests that the Late Prehistoric debitage collection represents a focus on tool production while the underlying component resembles an assemblage focused more on core reduction. This pattern suggests that site activities may have changed over time.

The low-density cultural remains have been impacted by bioturbation and vegetation clearing or plowing and their research potential is severely limited. CAR recommends that the portion of the site tested during the investigations reported herein, along with the materials recovered, do not contribute to the State Archeological Landmark eligibility of 41BP678. We therefore recommend that the planned construction be allowed to proceed. We also recommend that the portion of the site located to the south of the area tested by CAR remain protected.

All artifacts collected during this project are curated at the Center for Archaeological Research according to Texas Historical Commission guidelines. 


\section{Table of Contents}

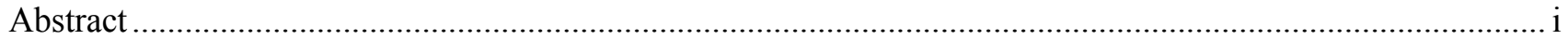

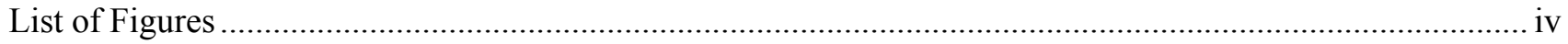

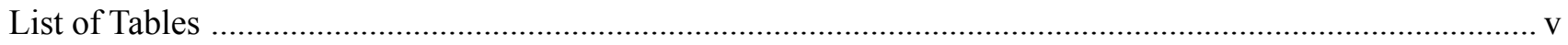

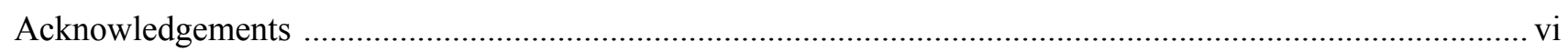

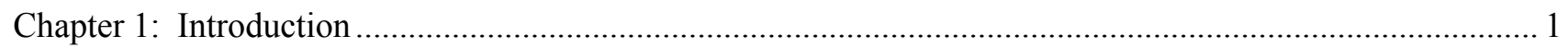

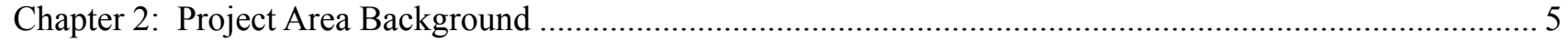

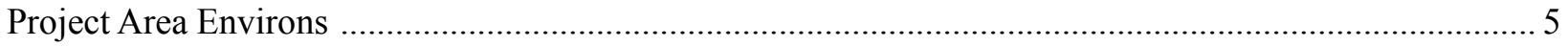

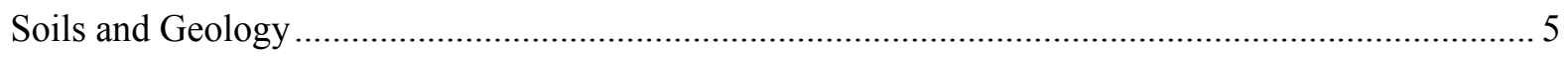

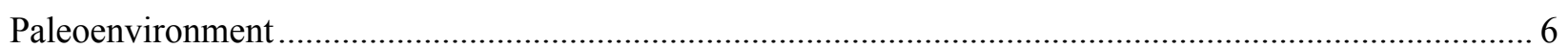

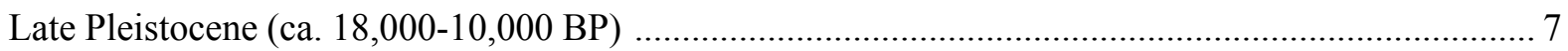

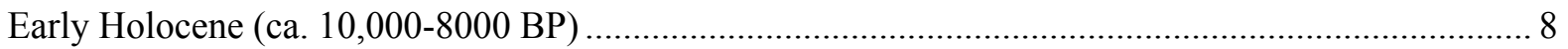

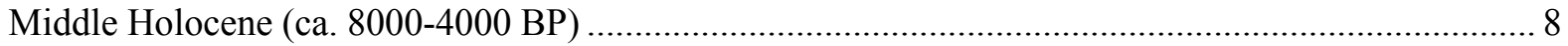

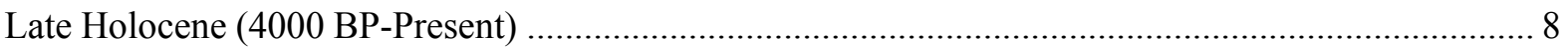

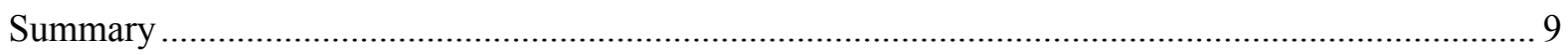

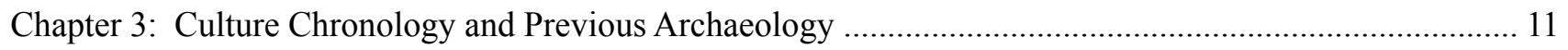

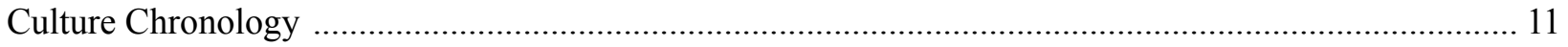

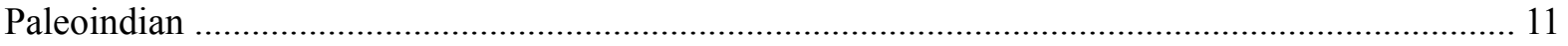

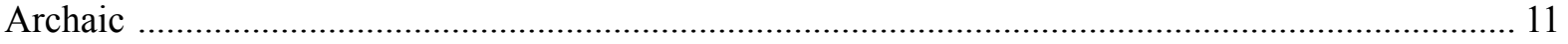

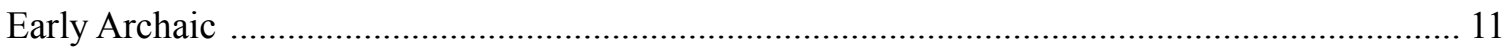

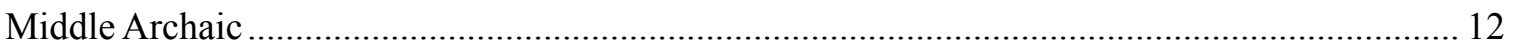

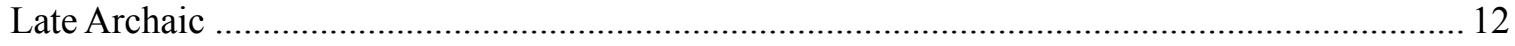

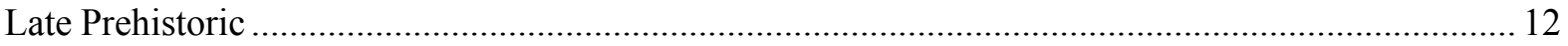

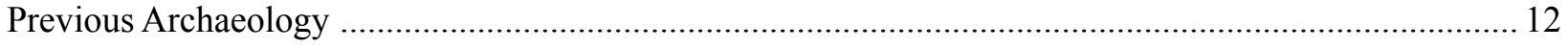

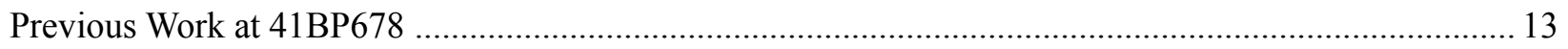

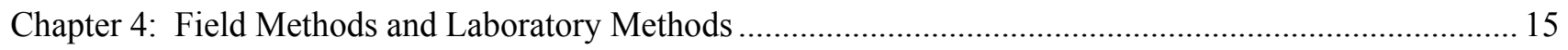

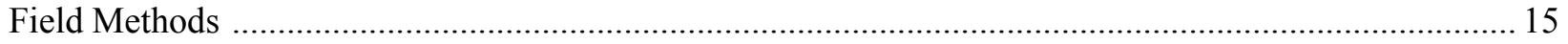

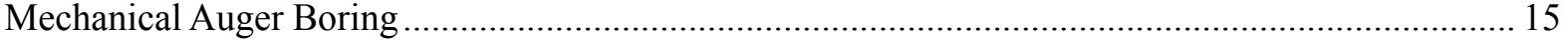

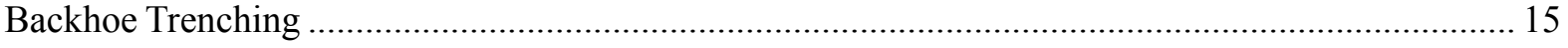

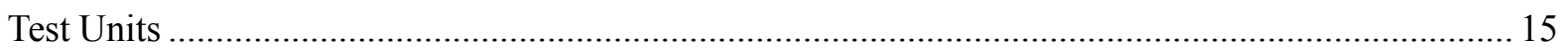

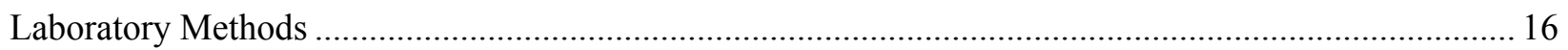

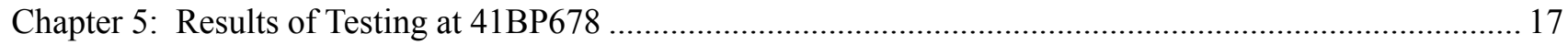

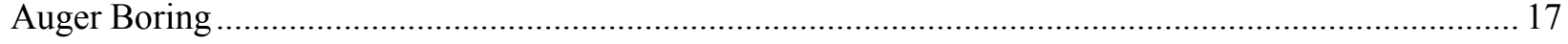

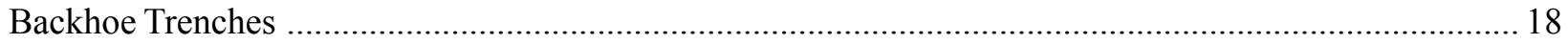




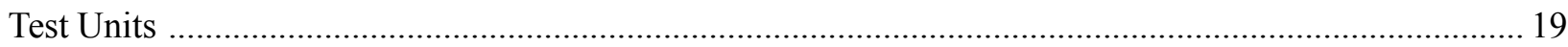

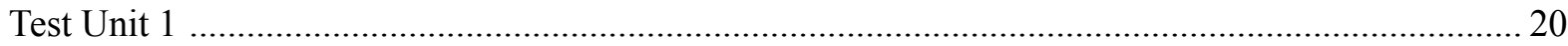

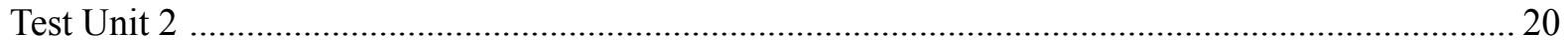

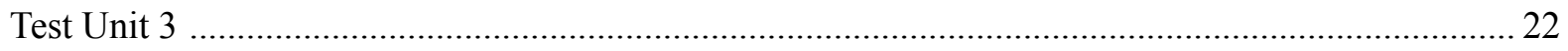

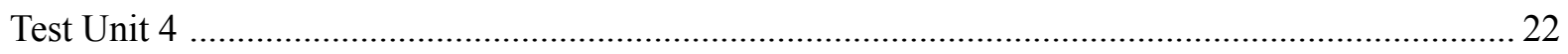

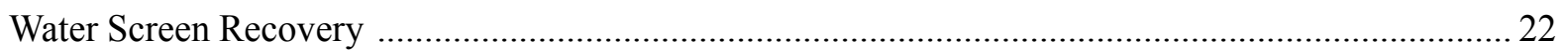

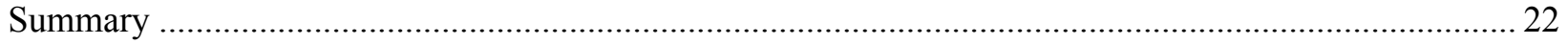

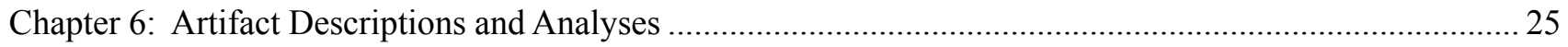

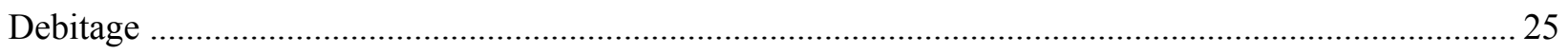

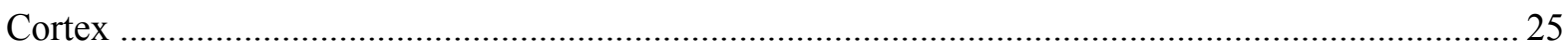

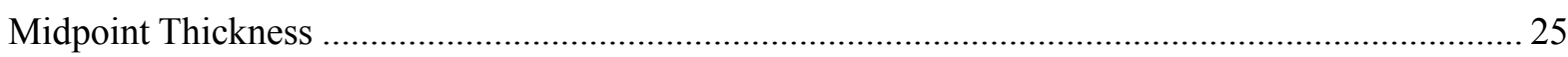

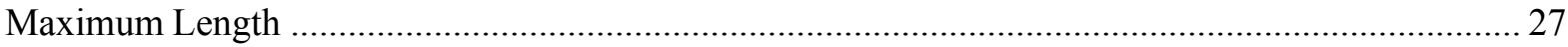

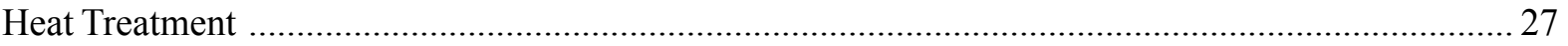

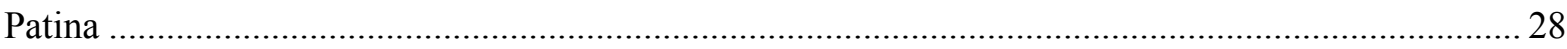

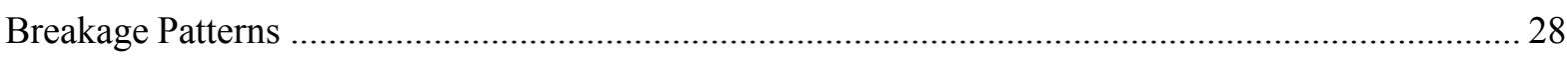

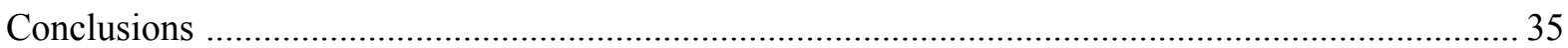

A Comparison of Debitage Assemblages from 41BP678 and 41BP679 …............................................ 35

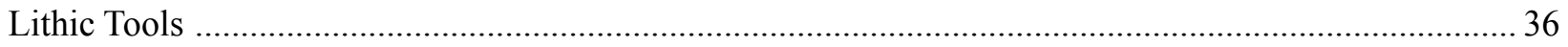

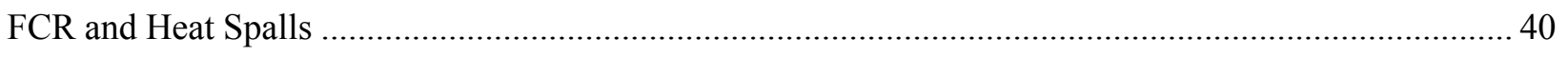

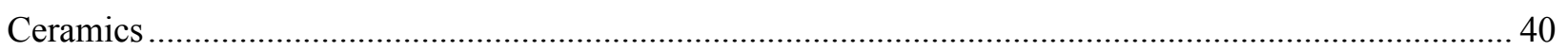

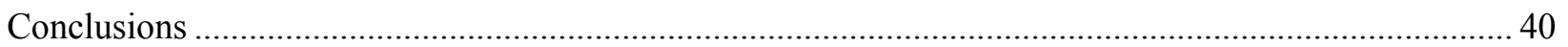

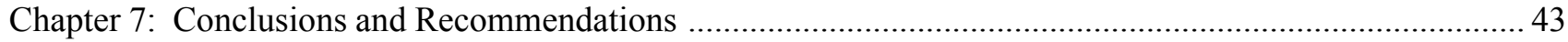

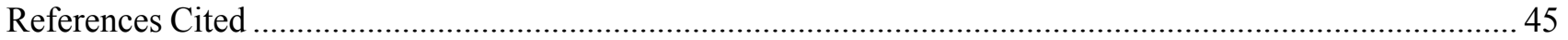




\section{List of Figures}

Figure 1-1. Location of project area in central Bastrop County. 1

Figure 1-2. Project area showing the proposed City of Bastrop Wastewater Treatment Plant and related

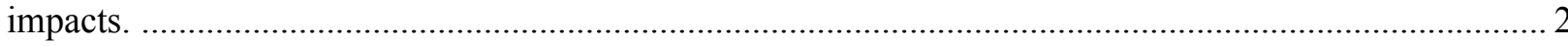

Figure 1-3. The project area, displaying future facilities and Areas of Potential Effect on 41BP678............... 3

Figure 2-1. Distribution of chert availability throughout Texas (after Mauldin and Figueroa 2005)................. 6

Figure 2-2. Photograph of the stream bed of Spring Branch Creek and chert material................................... 7

Figure 2-3. A collection of paleoenvironment data for the Texas region..................................................... 9

Figure 5-1. Location of mechanical auger tests, backhoe trenches, and test units excavated within the project

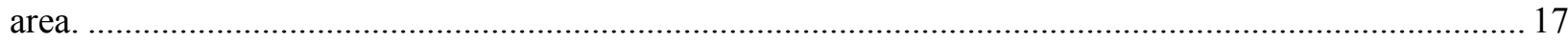

Figure 5-2. Mechanical auger testing along the northwestern portion of the site. ...................................... 18

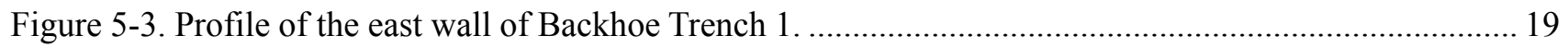

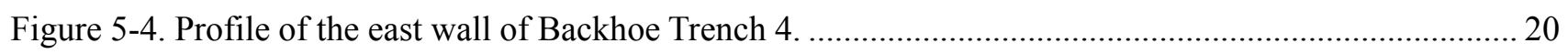

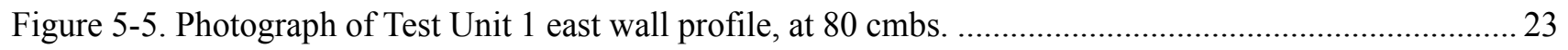

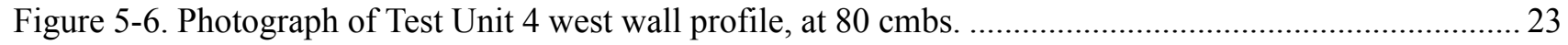

Figure 5-7. Vertical distribution of all artifacts from test units at 41BP678 ..............................................2 24

Figure 6-1. Percentage of tertiary flakes of 39 assemblages from Texas. .................................................... 26

Figure 6-2. Breakage patterns of debitage for upper and lower components. ................................................ 30

Figure 6-3. Comparison of upper and lower components with experimental assemblages from Amick and

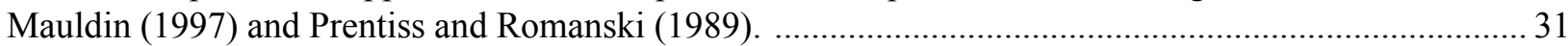

Figure 6-4. Boxplots comparing breakage patterns to (a) maximum length and (b) midpoint thickness in the

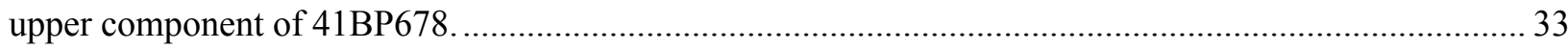

Figure 6-5. Boxplots comparing breakage patterns to (a) maximum length and (b) midpoint thickness in the lower component of 41BP678.

Figure 6-6. Breakage patterns for experimental debitage assemblages (Amick and Mauldin 1997 [A\&M];

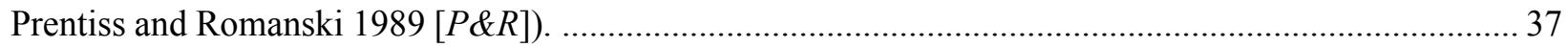

Figure 6-7. Comparison of 41BP678 and 41BP679 debitage assemblages according to breakage patterns. .... 38

Figure 6-8. Comparison of Bastrop County sites (41BP678 and 41BP679) and Caldwell County site

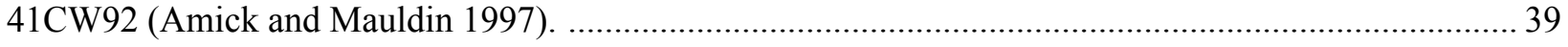

Figure 6-9. Cobble tool (chopper) encountered during auger testing of 41BP678 ...................................... 41

Figure 6-10. Early reduction biface encountered during auger testing of 41BP678. .................................... 41

Figure 7-1. Highlighted area showing portion of site 41BP678 not contributing to the eligibility of the site. 


\section{List of Tables}

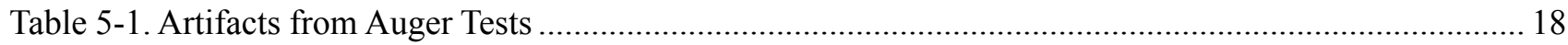

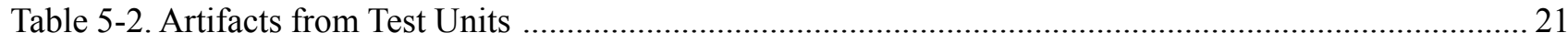

Table 5-3. Material Recovered from Water Screening ............................................................................. 24

Table 6-1. Cortex Percentages Displayed for Upper and Lower Components of 41BP678 ........................... 25

Table 6-2. Size Grouping (above and below $23 \mathrm{~mm}$ ) and Cortex Percentages .............................................. 27

Table 6-3. Presence or Absence of Patina by Component …......................................................................... 28

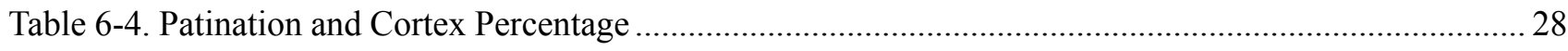

Table 6-5. Flake Fragement Percentages for Tool versus Core Reduction Assemblages .............................. 29

Table 6-6. Debitage Analysis Attributes According to Breakage Patterns ....................................................... 32

Table 6-7. Cortex Percentage Comparisons between 41BP678 and 41BP679 ............................................... 35

Table 6-8. Heat Treated Specimens from 41BP678 and 41BP679 ............................................................ 35

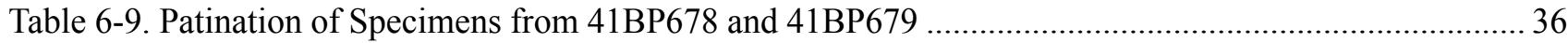

Table 6-10. Breakage Patterns among Debitage from 41BP678 and 41BP679 ........................................... 36 


\section{Acknowledgments}

The author would like to thank the several individuals that aided in completing this project. Special thanks and appreciation to Gene Kruppa, with BEFCO Engineering, Inc. and to James Miller and Jimmy Hanna of the City of Bastrop for help during the fieldwork. Heartfelt thanks to the field crew, which consisted of Jon Dowling, Joe Thompson, Leonard Kemp and Jason Perez. They worked very hard despite the extreme heat, flooded trenches and incessant ant attacks. Special thanks to Dr. Raymond Mauldin, CAR Assistant Director and Dr. Steve Tomka, CAR Director, for assisting with the lithic analysis and providing comments and suggestions during the production of the draft report. Cindy Munoz, who served as Project Archaeologist on the testing phase of 41BP679, aided me tremendously with the report, by discussing ideas and analysis results with me. Thanks to Kristi Ulrich, who served as the Principal Investigator. The author would also like to thank Bruce Moses for aiding with field logistics and drafting report figures. Claudia Branton, CAR editor, also assisted with report figures and produced the final version of the report. 


\section{Chapter 1: Introduction}

This report discusses the archaeological testing of site 41BP678 that occurred between April 27 and May 4, 2006. The site was identified in 2004 (Moses 2004) during an intensive pedestrian survey of a 26.5 -acre property owned by the City of Bastrop. Two archaeological sites were documented during the survey, 41BP678 and 41BP679. In 2005 the Texas Historical Commission (THC), in accord with the City of Bastrop, formally listed both sites as State Archaeological Landmarks (SALs).

The site and project area is located in Bastrop County, Texas along the banks of the Colorado River (Figure 1-1). The excavations were proposed in conjunction with plans by the City of Bastrop to build a water and wastewater treatment facility that would impact approximately 4.47 acres of the 26.5-acre tract including parts of 41BP678 and 41BP679 (Figure 1-2; see also Munoz 2006). Specifically, the proposed water and wastewater treatment facility will consist of an entrance drive and parking areas, a lift station, maintenance building, and primary, secondary, and tertiary treatment facilities to be constructed in the northwestern portion of the property (Figure 1-2). An additional 430 -m-long outfall pipe will be installed across the central and eastern portions of the property to empty discharge into the Colorado River via Spring Branch Creek, a small tributary creek bordering the tract along its southern margin. Within this Area of Potential Effect (APE), the construction of a Parshall flume, a small rectangular structure used for flow measurement, will require excavation approximately 3 feet deep $(0.9 \mathrm{~m})$. The outfall pipe will originate at the

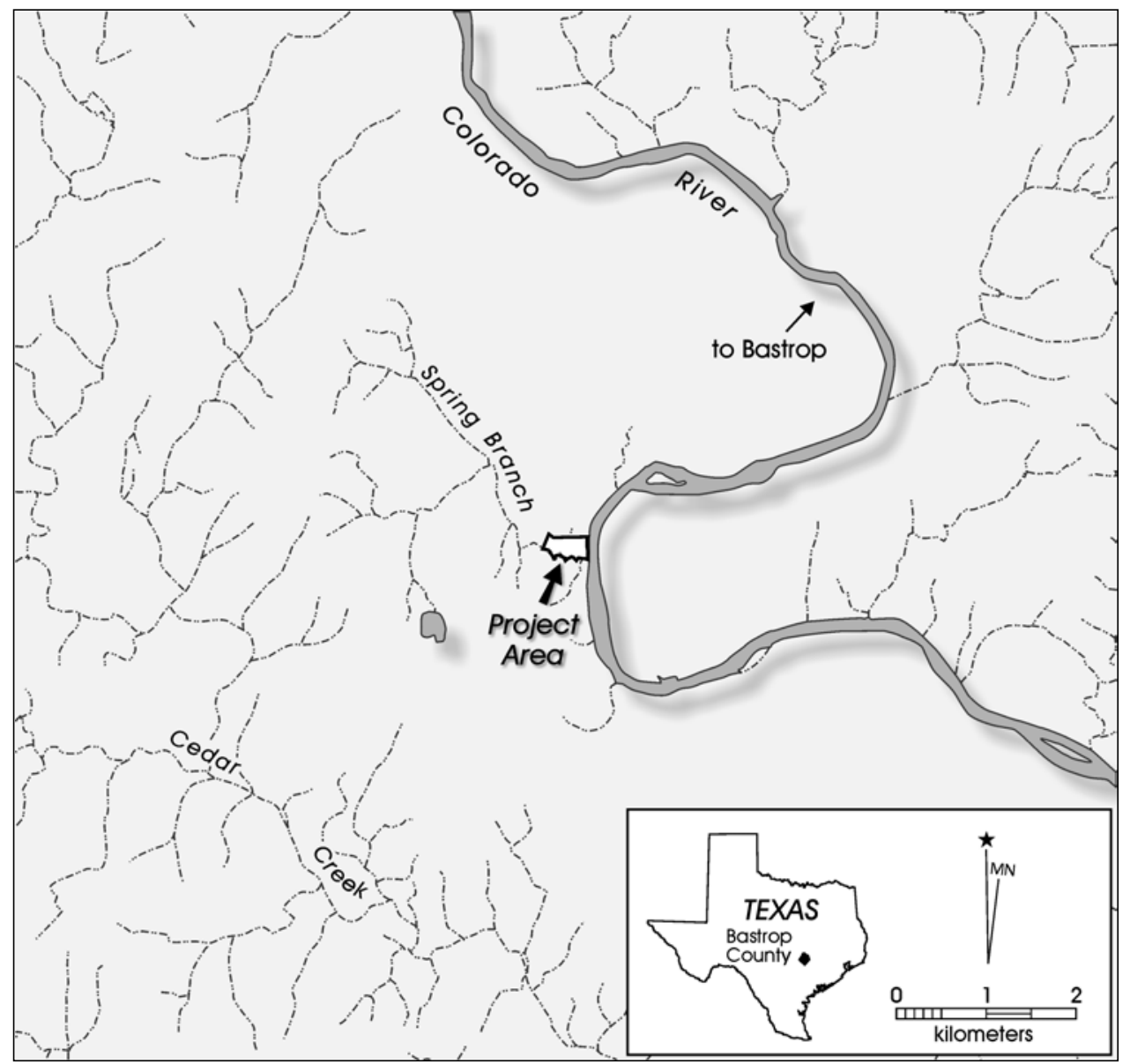

Figure 1-1. Location of project area in central Bastrop County. 


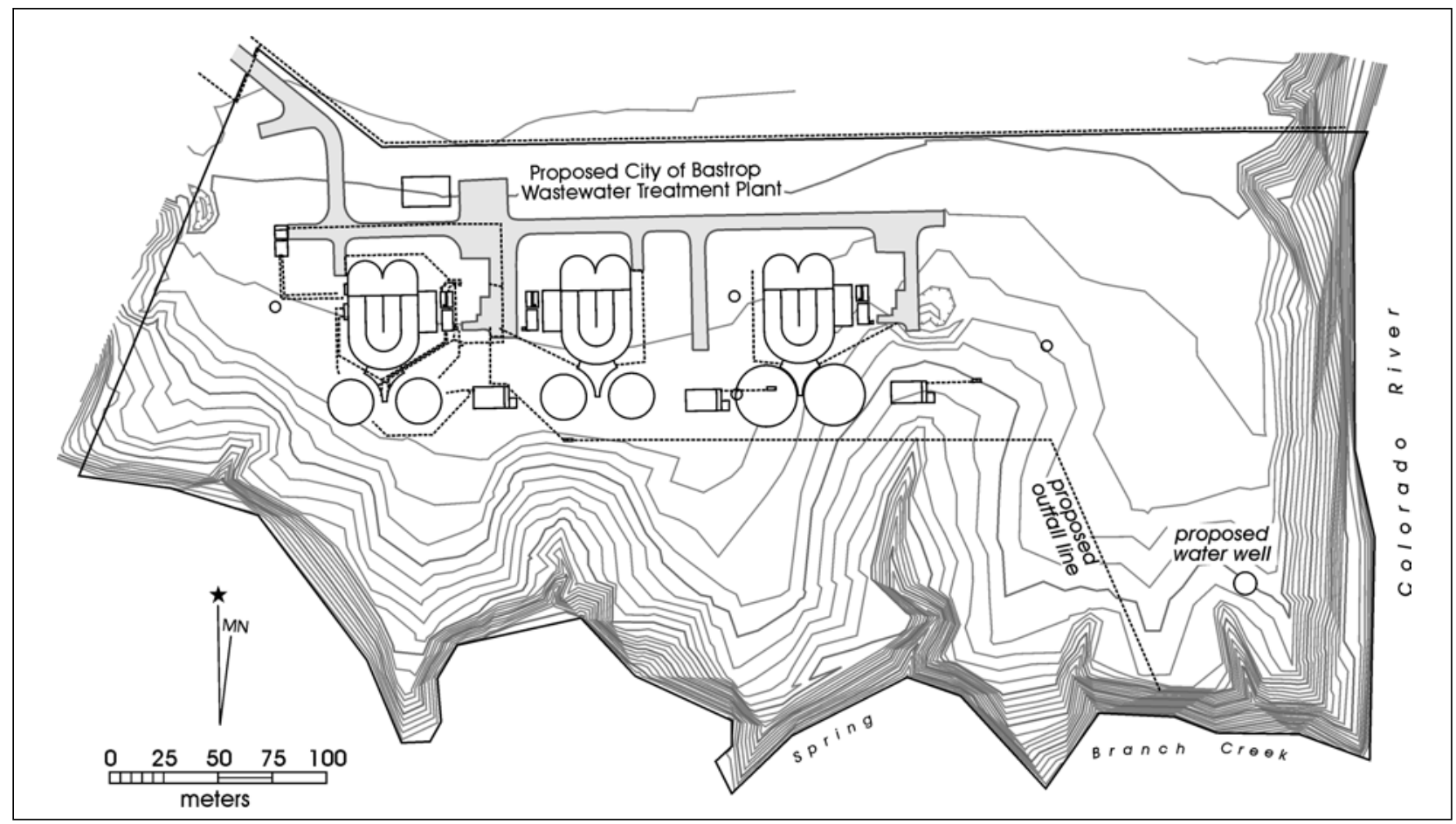

Figure 1-2. Project area showing the proposed City of Bastrop Wastewater Treatment Plant and related impacts.

flume and will require a maximum excavation to about 10 feet along portions of its route. A water well and associated piping will be installed parallel to the Colorado River at the eastern edge of the property.

While the entire APE of the facility construction measures roughly 4.5 acres, 41BP678 will be directly impacted by the installation of the eastern one-third of the outfall line and the construction of the well and installation of associated utilities (Figure 1-3). The sloping terrain along the eastern route of the outfall line will require shallower trench excavations; along the western portion of its route the outfall line will be installed as deep as 10 feet below surface. The excavations associated with the water well will extend as much 500 feet below the surface. The pipes leading away from the well will be installed to a maximum depth of four feet.

Because the site is listed as an SAL, the eligibility of 41BP678 is not in question. However, the proposed work will impact portions of the site. Therefore, the City of Bastrop contracted with the Center for Archaeological Research to design and conduct excavations to determine if the portions of 41BP678 that will be impacted by the planned construction of the water treatment plant contained deposits that contributed to the eligibility of the site. A secondary goal of the investigations was to better define the boundaries and temporal affiliation of the components noted at 41BP678 during survey. The testing involved a combination of mechanical augering, backhoe trenching, and the hand-excavation of test units. The archaeological testing of 41BP678 was performed under Texas Antiquities Permit No. 4117, with Kristi Ulrich serving as the Principal Investigator and Antonia Figueroa serving as the Project Archaeologist.

The testing of 41BP678 included the mechanical excavation of 79 auger test bores, four backhoe trenches and four $50-\mathrm{x}-50-\mathrm{cm}$ test units. The auger bores, backhoe trenches and test units were positioned along the northern site boundary and along the routes of planned fallout pipes to better define site boundaries, inspect the locations that will be directly impacted by the proposed development, and define the horizontal and vertical distribution of cultural materials. With the exception of the route of the fallout pipeline and the proposed well, the southern half of the site was not investigated because it is outside of the building restriction line and will not be directly impacted by any proposed construction activities. 
This page has been

redacted because it

contains restricted

information. 
portion of 41BP678 has not been tested, we further recommend that this southern portion remain off limits with regard to any construction activities.

The report is organized into seven chapters. Chapter 2 will review the environs of the project area that will include a discussion of the paleoenvironment. The culture chronology and previous archaeology conducted in the Bastrop County area will be presented in Chapter 3. Field and laboratory methods employed during the testing of 41BP678 will be discussed in the Chapter 4, followed by a discussion of the results of excavations in Chapter 5. Chapter 6 provides a description of artifact types and analysis. Chapter 7 will conclude the report with a summary of the testing phase results and recommendations for the site. 


\section{Chapter 2: Project Area Background}

This chapter reviews the environment of the project area, including aspects of climate, vegetation regimes, soils and raw material availability. This chapter also presents data on the paleoenvironment that have been collected for this region of Texas.

\section{Project Area Environs}

The project area is located on the 1982 Bastrop 7.5-minute USGS quadrangle map, just southeast of the Edwards Plateau below the Balcones Escarpment along the Colorado River. The region is typically humid and subtropical with cool winters and hot summers (Baker 1979). Rainfall distribution is almost even throughout the year with a slight increase between April and June and again in September. Average annual rainfall for Bastrop County is 37.18 inches (Baker 1979). Temperatures range from an average low of $58.2^{\circ} \mathrm{F}$ to an average high of $78.9^{\circ} \mathrm{F}$ (Baker 1979).

A large portion of the 26.5-acre project area shows evidence of recent plowing, and at the time of the initial survey the field was overgrown in sunflower (Helianthus annuиs). During the 2006 testing phase, the area was clear of major vegetation with the exception of the river banks and areas along the two drainages that are associated with 41BP678. The area is largely a Post Oak Savannah floral province and in this regime, non-pastured area vegetation consists largely of post oak (Quercus stellata) and blackjack oak (Quercus marilandica) with some black hickory (Carya texana) dominating the upperstory (Gould 1969:11). The understory consists of flora typical of tall grass prairies dominated by little bluestem (Schizachyrium scoparium). Also present in the understory are switchgrass (Panicum virgatum), purpletop (Tridens flavus), silver bluestem (Bothriochloa saccharoides), and Texas wintergrass (Stipa leucotricha). Portions of the project area nearer to the Colorado River floodplain include more water-tolerant hardwoods such as ash (Fraxinus americana), pecan (Carya illinoinensis), water elm (Ulmus sp.), hackberry (Celtis laevigata), water oak (Quercus nigra), willow oak (Quercus phellos), cottonwood (Populus deltoides), and black willow (Salix nigra).

Bastrop County is in the Texan biotic province (Blair 1950). The common mammalian species found in this region include white-tailed deer (Odocoileus virginianus), eastern cottontail rabbit (Sylvilagus floridanus), raccoon (Procyon lotor), opossum (Didelphis virginiana), and fox squirrel (Sciurus niger). There are also numerous bird species common throughout the county including the northern bobwhite (Colinus virginianus), eastern meadowlark (Sturnella magna), mourning dove (Zenaida macroura), killdeer (Charadrius vociferous), field sparrow (Spizella pusilla), red-tailed hawk (Buteo jamaicensis), and belted kingfisher (Ceryle alcyon).

\section{Soils and Geology}

Soils in the project area are in the Bosque-SmithvilleNorwood series (Baker 1979). These soils are associated with the lower terraces of the Colorado River. These soils have a loamy surface layer and moderately permeable lower layers. Bosque soils occur on relatively flat but dissected terraces averaging 40 to 50 feet above the current river level. The upper portions of Bosque series soils are composed of loam and transition to clay loam with depth (Baker 1979). Smithville and Norwood soils are deep, nearly level, well drained, loamy soils. Norwood soils occur on flood plains with Smithville soils on low terraces (Baker 1979).

The geologic strata exposed within the project area consist primarily of fluviatile terrace deposits laid down during the late Pleistocene. The Colorado River's winding dendritic course has filled the river valley with as much as 70 feet $(21 \mathrm{~m})$ of sediment in some places. Combinations of gravel, sand, silt and clay in varying proportions overlying older Cretaceous and Tertiary strata generally characterize these alluvial sediments (Barnes 1974). Along the Colorado River, these gravels include dolomite, limestone, chert, and quartz from the Edwards Plateau as well as various igneous and metamorphic rocks from the Llano region. Approximately $1.5 \mathrm{~km}$ west-northwest of the survey area, outcroppings of Calvert Bluff Formation, a Tertiary mudstone with varying amounts of sandstone and lignite, are common (Barnes 1974). Rocks from the Simsboro Formation are also present to the northwest and are composed of mostly sand, some mudstone, clay, and mudstone conglomerate.

Site 41BP678 is situated on the T2 terrace of the Colorado River. Given the high clay content of the matrix identified 
on the site it appears that deposits represent overbank sedimentation that occurred during flood events (see Chapter 5 for backhoe trench profile descriptions) rather than the result of colluvial, eolian or biogenic activities (Waters 1992). The lack of gravels in the sediment suggests low energy activity.

Site 41BP678 is located in an area of high raw material availability. As can be seen in Figure 2-1, high-quality cherts, common in Edwards limestone outcroppings, are located in the immediate area (Barnes 1974). Large quantities of tool stone are currently exposed in Spring Branch Creek (Figure 2-2) and two unnamed ephemeral drainages to the south of the site. A small sample of chert nodules was collected from these drainages in 2004 .
On average the maximum length of those nodules was around $17 \mathrm{~cm}$ and $5 \mathrm{~cm}$ in thickness.

\section{Paleoenvironment}

Several studies conducted in counties adjacent to the project area attempt to reconstruct paleoenvironmental conditions. For the purposes of this report paleoenvironmental conditions reconstructed for Central and East Texas are used (Abbott 1994; Bousman 1998; Mauldin 2006; Johnson and Goode 1994; Mahoney and Tomka 2001; Nickels and Mauldin 2001; Blum et al. 1994; Toomey 1993; see Figure 2-3). Data sets consist of pollen, faunal and geomorphic evidence. The geomorphic data reflect periods

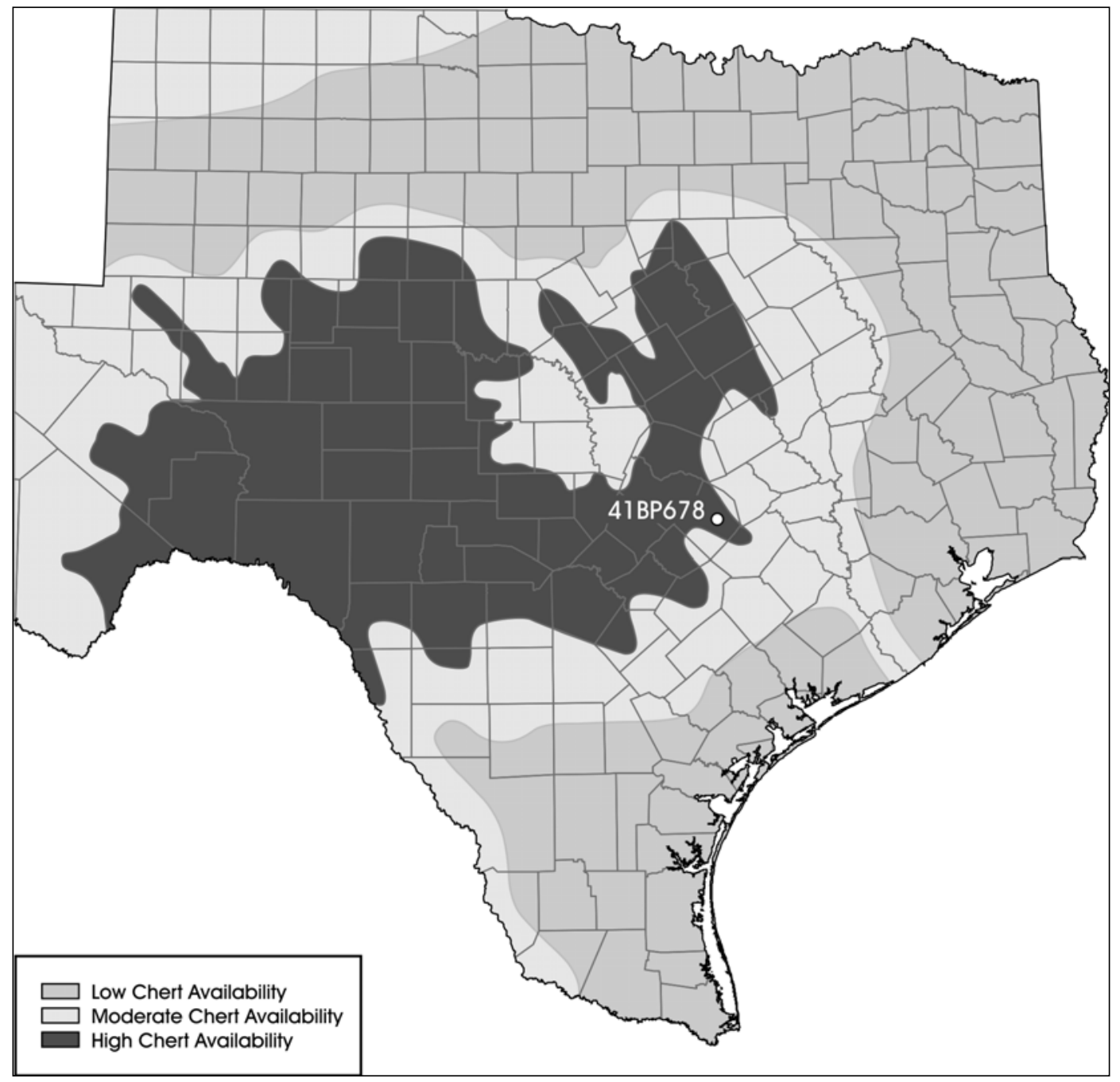

Figure 2-1. Distribution of chert availability throughout Texas (after Mauldin and Figueroa 2005). 


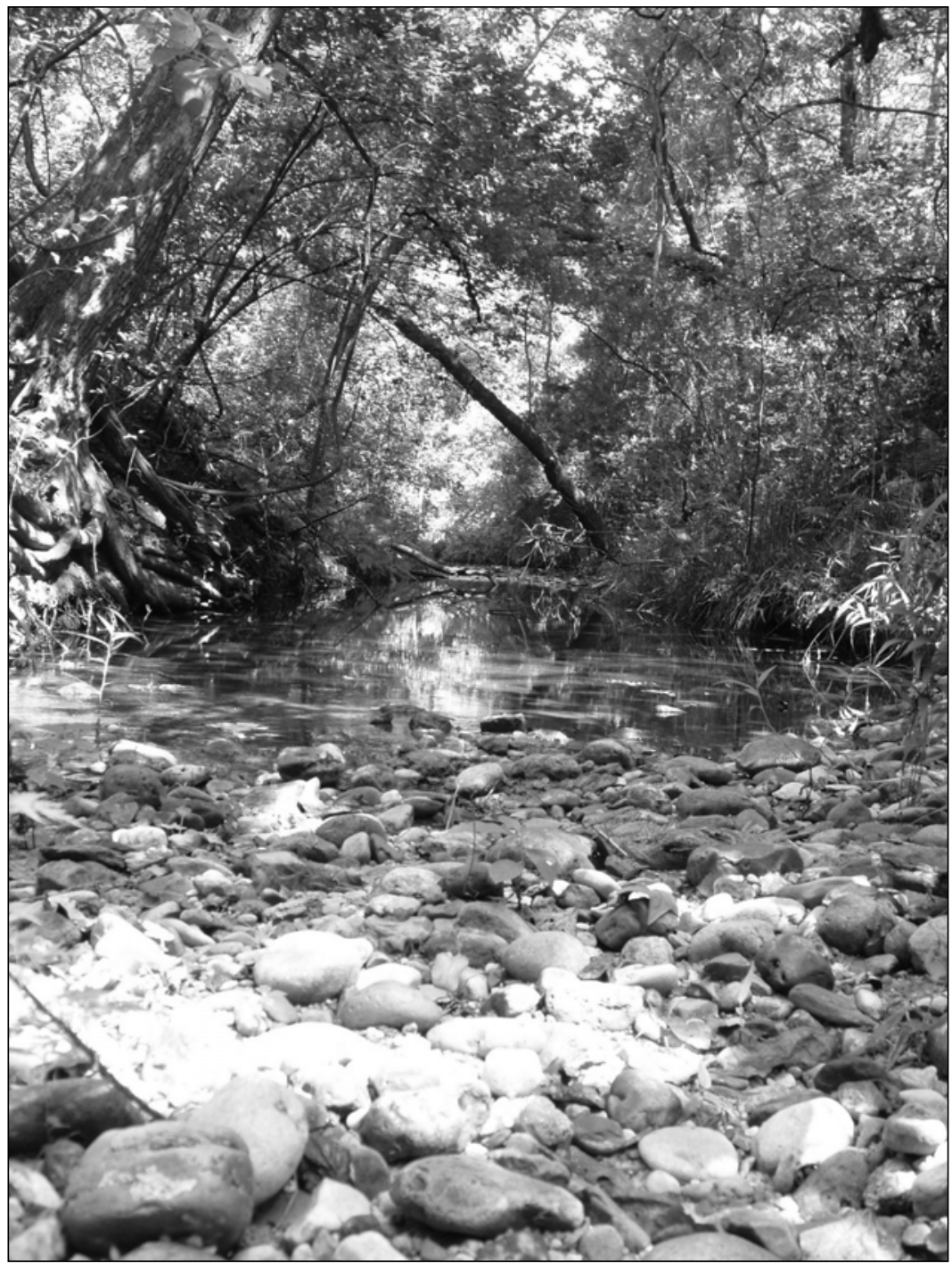

Figure 2-2. Photograph of the stream bed of Spring Branch Creek and chert material.

of sediment aggradation and erosion which can be used to interpolate prehistoric climatic conditions. Incisions likely occurred during times of severe dry periods followed by periodic downpours, resulting in heavy erosion.

The combined data suggest a wet Late Pleistocene and increasing drier Early Holocene. Though the climate during the Middle and Late Holocene periods appears to be divided by the lengthy "Dry Edward's Interval" dating from roughly 5000 to 3000 BP (Johnson and Goode 1994), after 3000 $\mathrm{BP}$, there seems to be a trend toward a more mesic climate.

\section{Late Pleistocene \\ (ca. 18,000-10,000 BP)}

Grassland vegetation dominated the Edward's Plateau from 20,000 to 14,000 BP, along the Pedernales and Upper Colorado Rivers. During the latter part of the late Pleistocene (14,000-11,000 BP) moisture decreased and channels incised bedrock valleys leaving no preserved depositional record. Geomorphic processes observed by Abbott (1994) along the Pedernales and Upper and Lower Colorado Rivers reflect soil aggradation and incision. 
Pollen data from Boriack Bog in Central Texas suggests a shift from grasslands before 16,000 BP to woodlands by 12,500 BP (Bousman 1998:79). The Boriack Bog data also indicate that a drier episode stimulated a brief shift to grasslands between 12,500 and 11,800 BP. Raw pollen counts from Patschke bog were reviewed and compared to Boriack Bog dates (see Nickels and Mauldin 2001). Between 17,000 and 15,000 BP, the Patschke bog data suggest that "a cool grassland environment may have been present" (Nickels and Mauldin 2001:35). With a few brief exceptions, trends in grass pollen percentages indicate that after 15,500 BP there was an abrupt decline in grass pollen, and by extension an increase in arboreal pollen, until roughly 10,500 BP (Mauldin et al. 2003:13-14).

Data from Hall's Cave in the Edwards Plateau (Toomey et al. 1993) indicate summer temperatures in the Late Pleistocene were significantly cooler than present averages. By around 12,500 or $13,000 \mathrm{BP}$, this cooler, wetter interval became warm and more arid (Toomey and Stafford 1994).

\section{Early Holocene (ca. 10,000-8000 BP)}

Data on the environmental conditions during the early Holocene are limited. Geomorphic evidence from Fort Hood and the Jonas Terrace site in Central Texas indicates "large-scale but brief climate shifts during the earliest Holocene" (Johnson and Goode 1994:21). Evidence from these two areas suggests a dry Early Holocene, with intervals of droughts and violent flooding. It appears that climatic shifts during the Pleistocene-Holocene transition are responsible for aggradation of soils along river systems (Abbott 1994:369). According to Blum and colleagues, the Early to Middle Holocene was characterized by warming and dry climate, accompanied by "a precipitation regime dominated by high-density but relatively localized convectional storms..." (Blum et al. 1994:15).

The Boriack and Weakly pollen records indicate climatic fluctuations and a possible return of woodlands by $9500 \mathrm{BP}$ (Bousman 1998). Woodlands were fully re-established by 8750 BP. A gradual warming trend is supported by consistent increase in grass pollen at Patschke Bog (Mauldin et al. 2003:14).

\section{Middle Holocene (ca. 8000-4000 BP)}

River courses along the Edwards Plateau were characterized by slow lateral migration and valley widening, with slow aggradation during this period (Blum et al. 1994). This xeric period was also characterized by severe erosion (Collins 1998, after Antevs 1955). Faunal evidence from Hall's Cave indicates an increasing dryness throughout this period (Toomey 1993).

Pollen evidence from Boriack Bog signifies a return of grasslands, suggesting drier conditions, that appear to begin around $7500 \mathrm{BP}$. By $5000 \mathrm{BP}$, grasslands appear to be well established (Bousman 1994). The Patschke data suggest a grassland setting was also present throughout this period, but with a brief shift to more mesic conditions between $6000 \mathrm{BP}$ and $5000 \mathrm{BP}$ (Mauldin et al. 2003:15). Bryant and Holloway (1985:55) use pollen from Ferndale Bog to document that particular floral taxa, adapted to drier conditions, increased. Conversely, sedge pollen, which may indicate moist environments, peaks at $6500 \mathrm{BP}$, and declines throughout the remainder of the Middle Holocene (Bryant and Holloway 1985:55).

\section{Late Holocene (4000 BP-Present)}

A fluctuation of vegetation regimes occurs throughout the Late Holocene. Pollen data from Milam County indicate a decrease in arboreal cover between 3200 and $3000 \mathrm{BP}$, with the next thousand years dominated by open grasslands (Mahoney and Tomka 2001). Oxygen and carbon isotope analysis of snail shell from 41MM341 suggests variation in temperature and rainfall between 3000 and 2500 BP (Mauldin 2006). Along the Edwards Plateau, high-magnitude floods are evident from about 2500 to 1000 BP. At this time large chute channels were cut and filled in floodplains that developed stable terrace surfaces (Blum et al. 1994). Nordt et al. (1994) suggest a warm and dry episode between 3000 and 1500 BP based on stable carbon ratios from deposits at Applewhite Reservoir. Toomey and Stafford (1994) see a wet period at about 2500 BP at Hall's Cave.

Aggradation of soil persists during the Late Holocene, with prominent incision and downcutting occurring after 1000 BP (Abbott 1994; Hall 1990). Grass pollen frequencies in the Boriack and Weakly Bog indicate drying episodes at 1600-1500 BP and again at 500-400 BP (Bousman 1994:80). Data from Patschke Bog indicate a fluctuating but generally dry period early in the Late Holocene, with accelerated mesic conditions after about 1000 BP (Mauldin et al. 2003:15). A notably wetter climate is evident in the environs of 41MM341 (Gadus et al. 2006) that correlates with moist conditions reconstructed for the Hall's Cave region (Toomey 1993). 


\section{Summary}

Pollen data, temperature reconstructions, and patterns of soil aggradation/incision from Central and East Texas are presented in Figure 2-3. Bousman's (1998) estimated canopy cover, extrapolated from pollen data, as well as the Patschke Bog pollen percentages (Nickels and Mauldin 2001), indicate mesic conditions in the Late Pleistocene with drier conditions increasing throughout the Early
Holocene. According to geomorphic evidence, the Pleistocene is a period of incision (dryness). During the Early and Middle Holocene, there is a steady accumulation of soil (aggradation) which can be interpreted as reflecting stable climate conditions. It is surprising that the distinct drying episode that is apparent during the Early Holocene in most climate proxy data is not marked by incision in the soil data. The "Dry Edward's Interval" is clearly exemplified

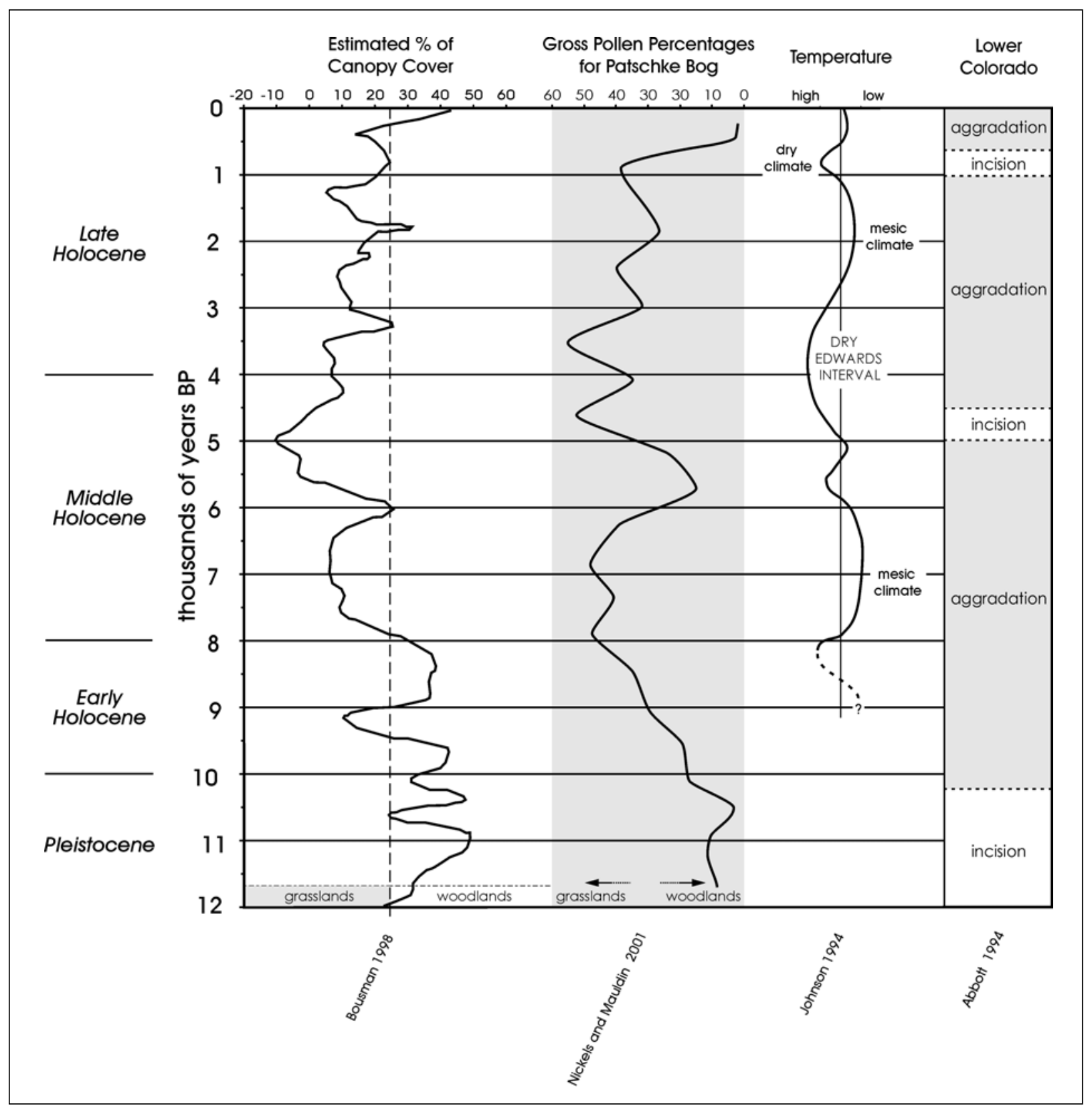

Figure 2-3. A collection of paleoenvironment data for the Texas region. 
in the pollen and temperature data, but is not pronounced in the geomorphic data. The climate of the Late Holocene shifts towards more mesic conditions (see Figure 2-3). Though the geomorphic data from the Lower Colorado does not illustrate the variation and the incremental trends that are noticeable in the pollen data, it does, along with Johnson and Goode's (1994) temperature estimates, give a broad interpretation of the paleoenvironment.

Various data sets signify the fluctuating climate conditions of ancient Texas. While, in part, this variability may reflect problems with comparing different proxy data sets that measure different aspects of climate at varying spatial and temporal scales, as well as problems with the temporal assignment of particular samples or sequences, the variability may be real, especially during certain periods. The end of the Pleistocene clearly marked a transition from a cooler, wetter environment to one that steadily grew warmer and drier. All the data sets indicate that much of the Early Holocene was relatively mesic. The Middle Holocene is indicated to be warm and/or dry, with a brief mesic period suggested sometime between 6000 and 5000 BP. Between about 1,500 and 750 years ago, most available data sets hint at a dryer period, while a more mesic interval is suggested for the last 750 to 800 years (see Figure 2-3). 


\section{Chapter 3: Culture Chronology and Previous Archaeology}

The chapter presents a review of culture chronology for Central Texas along with a summary of previous archaeology research in the immediate project area. The summary of previous research includes a detailed description of the findings at 41BP678 during the initial survey. The majority of the background material was adopted from the archaeological survey report of 41BP678 and 41BP679 (Moses 2004).

\section{Culture Chronology}

This section reviews the cultural chronology for Central Texas. That chronology has been summarized by several individuals (Black 1989; Collins 1995, 2004; Johnson and Goode 1994; Nickels et al. 2001b; Prewitt 1981; Weir 1976), and we rely heavily on these previous summaries in this section.

\section{Paleoindian}

The Paleoindian period marks the first appearance of humans in the New World. Early Paleoindian peoples have generally been perceived as hunter-gatherers utilizing large areas in pursuit of now extinct megafauna, such as mammoth and Bison antiquus. This view of Paleoindian peoples, much like the dating of this period, is now being reassessed (see Collins 2004). While certainly exploiting late Pleistocene megafauna, these peoples are perhaps more accurately characterized as generalized hunter-gatherers. Certainly by the later Paleoindian time-frame, after the extinction of these megafauna, the hunting aspect of subsistence shifted to exploitation of large herbivores like deer and Bison antiquus.

Traditionally, the Paleoindian period is first marked by the appearance of Clovis, and later Folsom points, in North America. The later Paleoindian period (10,000-8000 BP) is characterized by a variety of dart point types, including Plainview, Dalton, Angostura, Scottsbluff, and Golondrina (Black 1989). Despite changes in these various projectile point types through time, their geographic range is widespread, with high densities on the High Plains and Central Texas (Meltzer and Bever 1995).

\begin{abstract}
Archaic
The Archaic period can be broadly defined by changes in projectile point types, an increase in the number and types of sites (including burned rock hearths and middens), and by an increase in the variety of artifact styles, with many artifacts having more limited geographical distribution. While a number of finer subdivisions exist for the Archaic (e.g., Prewitt [1981], Weir [1976]), this period can be broadly divided into the Early, Middle, and Late Archaic.
\end{abstract}

\section{Early Archaic}

Collins (1995:383) dates the Early Archaic from 8800 to 6000 BP in Central Texas with three divisions based on projectile point types, while Hester (1995:436-438) identifies the Early Archaic with Early Corner Notched and Early Basal Notched dart points roughly dating between 7950 and $4450 \mathrm{BP}$. The extinction of large herds of megafauna and the changing climate at the end of the Pleistocene appear to have stimulated a behavioral change by the prehistoric inhabitants of Texas. While the basic hunter-gatherer adaptation probably remained intact, an economic shift away from big game hunting was necessary. In general, more intensive exploitation of local resources, such as deer, fish, and plant bulbs is indicated by greater densities of ground stone artifacts, fire-cracked rock cooking features, and more specialized tools such as Clear Fork gouges and Guadalupe bifaces (Turner and Hester 1998:246, 256). Weir (1976) speculates that Early Archaic groups were small and highly mobile, an inference based on the fact that Early Archaic sites are sparsely distributed and that diagnostic projectile point types are seen across a wide area, including most of Texas and northern Mexico. Hurt (1980) suggests that the decline in the number of bison on the plains forced the inhabitants to broaden their diets to pursue plants and animals which would produce the same amount of calories and protein with the same or slightly more effort expended. Story (1985) suggests that population densities were low during this period, and that groups consisted of related individuals in small bands with "few constraints on their mobility" (Story 1985:39). Their economy was based on the use of a wide range of resources, including prickly pear, lechugilla, rodents, rabbits, and deer (Story 1985:38). 


\section{Middle Archaic}

Collins (1995:383) defines this intermediate interval of the Archaic as lasting from about 6000 to 4000 BP in Central Texas, but Hester (1995:438-441) suggests that the period between 4450 and 2350 BP more correctly reflects the Middle Archaic in South Texas. The Middle Archaic appears to have been a time of increased population, based on the large number of sites from this period in South and Central Texas (Story 1985:40; Weir 1976:125, 128). A shift to concentrated, seasonal nut harvests in the riverine environments of the Balcones Escarpment seems to have occurred (Black 1989). Weir (1976) believes that an expansion of oak woodlands on the Edwards Plateau and Balcones Escarpment led to intensive plant gathering and acorn processing. He also believes that the widely scattered bands of the Early Archaic now began to coalesce, at least during the acorn-gathering season, into larger groups who shared the intensive work of gathering and processing the acorn harvest (Weir 1976:126).

\section{Late Archaic}

Collins (1995:384) dates the final interval of the Archaic in Central Texas to approximately 4000-800 BP. Hester believes the Late Archaic in South Texas may be better defined as between 2350 and 1250 BP, while Hofman's (1989:45) synthesis of these data places the Late Archaic on the Southern Plains at 3000-2000 BP, and possibly later. Some researchers argue that population densities increased throughout the Late Archaic (Prewitt 1981), while others feel densities remained stable, or actually declined during this period (Black 1989). Late Archaic points tend to be much smaller than those dated to the Middle Archaic. The most common Late Archaic types are Ensor and Ellis (Turner and Hester 1998:114, 122). They are both short, triangular points with corner notches. Finally, note that although inhabitants of the South Texas Plain near Brownsville and Rockport had begun to make pottery, possibly as early as $1750 \mathrm{BP}$, the northern part of the South Texas Plain remained "pre-ceramic" until 1,000 years later (Story 1985:45-47).

\section{Late Prehistoric}

The term Late Prehistoric is commonly used to designate the period following the Late Archaic in Central and South Texas. Collins (1995:385) recognizes that the commonly used date of 1200 BP for the end of the Archaic and beginning of the Late Prehistoric in Central Texas is arbitrary, and Hester (1995:442) acknowledges the problematic issue of selected tools appearing at both Late Archaic and Late Prehistoric sites. A series of distinctive traits mark the shift from the Archaic to the Late Prehistoric period, including the technological shift to the bow and arrow and the introduction of pottery to Central Texas and the northern South Texas Plain (Black 1989; Story 1985). Most researchers agree the early Late Prehistoric period was a time of population decrease (Black 1989). Cemeteries from this period often reveal evidence of conflict (Black 1989). Radiocarbon evidence indicates burned rock middens are intensively used during this period (Black and Creel 1997; Mauldin et al. 2003).

Beginning rather abruptly at about $650 \mathrm{BP}$, a shift in technology occurred. This shift is characterized by the introduction of blade technology. Ceramics are being used in East Texas by $2450 \mathrm{BP}$, while the first ceramics in Central Texas (bone-tempered plain wares) did not make an appearance until ca. 650/700 BP (Perttula et al. 1995). The period is also distinguished by the appearance of Perdiz arrow points, and alternately beveled bifaces (Black 1989). Prewitt (1981) suggests this technology encroached from north-central Texas. Hester (1995:444) recognizes this phase (Toyah) as the "best documented Late Prehistoric pattern" throughout South Texas, with dates ranging between ca. 300/350 and 650/700 BP.

\section{Previous Archaeology}

Among the earliest attempts to document prehistoric life in the region is A. M. Wilson's (1930) unsystematic survey of Bastrop and Wilson counties. Unfortunately, Wilson's sketchy descriptions and lack of reliable provenience data make it all but impossible to relocate many of the sites accurately on the state site file maps (Bement 1989; Klinger et al. 1999; Moses 2004). In 1953, T. B. Campbell and E. R. Jelks of the University of Texas at Austin excavated two Late Prehistoric burials at 41BP1 (Skelton and Freeman 1979:21). Seventeen additional sites were recorded and tested in Bastrop County between 1962 and 1968 by the University of Texas at Austin. Site 41BP51, a possible Paleoindian site, was recorded in 1966. The most notable of these recorded sites are the McCormick Site (41BP3), the Pease Site (41BP5), and several sites near the Powell Bend Prospect along Big Sandy Creek (Kenmotsu 1982). 
In 1972, Paul Duke documented the Thunderbird Lake Site (41BP78) near Smithville and recorded an extensive lithic concentration with diagnostic artifacts that included Paleoindian and Late Prehistoric specimens (Duke 1977). Several cultural resources studies have been carried out at Camp Swift in the northern portion of the county. These studies have produced a comprehensive record of all stages of Bastrop County prehistory (Nickels et al. 2001a; Robinson et al. 2001; Schmidt and Cruse 1995; Skelton and Freeman 1979).

In 1985 and 1986, David G. Robinson and Solveig A. Turpin, in association with the Texas Archeological Survey, carried out an archaeological survey of selected lowland riverine zones in Bastrop County as a part of the Bastrop County Historical Commission's Sesquicentennial Project (Moses 2004; Robinson 1987). That project included the current project area. Although no archaeological sites were observed within the current project boundary, four archaeological sites were identified to the south of the project area on the banks of the Colorado River. Site 41BP311 is the largest and closest of these sites to the project area. It is located on the southern bank of Spring Branch Creek. The site consists of copious amounts of lithic debitage, burned rock, deer bones and shell scattered across approximately 10 acres. A single shovel test was placed within the site boundary and cultural materials were also observed to a depth of $30 \mathrm{~cm}$ in gravel pit profiles (THC 2006). A single looter's excavation pit was observed on site. The site is assumed to be of Archaic age, although no temporally diagnostic artifacts have been recovered. Immediately south of 41BP311, a second prehistoric site was recorded, 41BP50. Here, a buried midden was exposed in a gravel pit excavated by a bulldozer. Choppers, cores, debitage, finished bifaces and a Clear Fork tool were reported as having been recovered from 41BP50. Site 41BP51 was identified farther south of 41BP50. This is also a buried site, identified in a ditch excavated for pipe installation. A number of dart point types were recovered from the ditch backdirt and at least one of the specimens is a Paleoindian point while another is an Archaic Carrizo type (Turner and Hester 1998:84). It is unclear exactly how deep the artifacts were buried. The southernmost site in the vicinity of the project area recorded by Robinson is 41BP48 (Robinson 1987). This site was identified from a surface scatter of artifacts, although some of the materials appeared to be shallowly buried. Large quantities of burned rock, debitage and bifaces were present on the surface. Late Prehistoric, Archaic and Paleoindian temporally diagnostic artifacts were collected from 41BP48.
While none of these four sites are within the current project area, the fact that at least three of them contain buried deposits suggests that they have some research value. Unfortunately, the level of work conducted on these sites at the time of their discovery was not sufficient to establish whether they have stratified or disturbed components. The presence of Paleoindian artifacts, as well as later materials, indicates a long span of use and occupation of the region. Furthermore, the evidence of looters' excavations suggests these resources are in danger of additional impacts.

The Kennedy Bluff Site (41BP19) is located southeast of the project area along State Highway 71 and the banks of the Colorado River. Testing at the site in 1985 by the Texas Archeological Research Laboratory, in collaboration with the Texas Department of Transportation (TxDOT), yielded evidence of Early Archaic burned rock features (Bement 1989). Thermoluminescence and ${ }^{14} \mathrm{C}$ dating were conducted on nine features that produced date ranges from $740 \pm 90$ to $9600 \pm 800$. However, no artifacts were associated with the features. Furthermore, the vertical and horizontal distribution of artifacts did not correspond to the dates offered by the radiocarbon and thermoluminescence data. Early Archaic tools were recovered but they were from a mixed context.

\section{Previous Work at 41BP678}

During the 2004 survey (Moses 2004), 41BP678 was described as a light surface scatter of lithics across the upland landform and this scatter extends to the edge of the bluff to the south and east. A single piece of burned rock was recorded on the surface at the southwestern portion of the site, and about two dozen lithic artifacts, including cores, tested cobbles, and primary and secondary flakes, were observed in an adjacent drainage. This scatter extends for almost $40 \mathrm{~m}$ along the drainage, which appears to have been used as a lithic procurement area. A similar lithic scatter was also observed in a second drainage some $70 \mathrm{~m}$ east of the first scatter.

Four of the five shovel tests excavated on 41BP678 contained cultural material. Shovel tests were excavated to a depth of $60 \mathrm{cmbs}$. In all, six pieces of debitage, two pieces of burned rock, and two mussel shell fragments were recovered from the four positive shovel tests. Two shovel tests (Shovel Test [ST] 1 and ST 2) were excavated near the eastern bluff overlooking the Colorado River, and lithic debitage was recovered in both units between 40 and $60 \mathrm{cmbs}$. 
Debitage was also observed on the surface near each of these excavations. ST 20 was placed about $50 \mathrm{~m}$ west of ST 1 in order to ascertain the presence and depth of cultural deposits between ST 1 and Backhoe Trench (BHT) 4. Two flakes were recovered from this shovel test between 10 and 20 cmbs. ST 21 was excavated near the bluff at the southwest corner of the site and produced a single flake between 10 and $20 \mathrm{cmbs}$. A fifth shovel test, ST 3, was also excavated near the bluff along the southern portion of the site but did not contain cultural materials. A large tested cobble, however, was observed on the surface in the immediate vicinity of ST 3.

Three backhoe trenches excavated within the site boundary also contained cultural materials. Backhoe Trench 2 was placed along the bluff of the Colorado River approximately $50 \mathrm{~m}$ north of ST 1 and was positive for cultural artifacts including small quantities of lithic debitage, a single burned rock fragment and bone observed in the backdirt. In addition, snails (Rabdotus) were present at varying depths from the surface to $65 \mathrm{cmbs}$. Thus, BHT 2 forms the northernmost positive excavation within 41BP678. BHT 3 was located between ST 1 and ST 2 near the eastern edge of the site. Artifacts observed in the backdirt included one tested cobble and one piece of heavily patinated cortical debitage. No artifacts were observed in situ. Sediments in this area were markedly different than those observed in other portions of the APE and included a thick Bt horizon of gravelly sand/clay that contained several thick lenses of developing calcium carbonate. BHT 4 was placed on a low rise to the northwest of BHT 3 in order to test areas farther away from the drainages. A single flake was observed in the backdirt, though no cultural material was observed in situ. Rabdotus shells were recorded from the surface to 50 cmbs. BHT 1 was placed off-site.

The final survey report submitted to the THC discussing the archaeological survey of 41BP678 and 41BP679 concluded that there was insufficient information to make determinations on the eligibility for listing on the National Register of Historic Places (NRHP) or for SAL designation of the sites (Moses 2004). It was recommended that if the wastewater treatment facility could not be moved a testing phase would be necessary to determine the eligibility status of both site 41BP678 and 41BP679. Subsequent to the submission of the final report to the THC for review, the THC, in conjunction with the City of Bastrop, formally listed both sites as State Archeological Landmarks. 


\section{Chapter 4: Field Methods and Laboratory Methods}

The proposed construction of the water treatment facility and associated piping will impact 41BP678. The previous investigations indicated that 41BP678 had probable intact deposits and it was designated as a State Archaeological Landmark. The ages of the two components identified during the survey were not known at the time of testing. Consequently, the work outlined in the Scope of Work was designed to (1) determine if the proposed construction of the treatment plant and associated facilities would adversely impact archaeological deposits that contributed to the eligibility of the sites; and (2) better define spatial and temporal boundaries for 41BP678. This chapter will discuss the field methods employed during archaeological investigations of 41BP678, along with laboratory methods and curation of artifacts and documents.

\section{Field Methods}

Several excavation techniques were used during the testing of 41BP678, including auger boring, backhoe trenching and the hand-excavation of test units. Mechanical auger boring was employed prior to backhoe trenching and test units to determine the horizontal distribution of cultural material and search for features on the site. Once auger boring was completed four backhoe trenches were excavated, followed by four $50-\mathrm{x}-50-\mathrm{cm}$ test units.

\section{Mechanical Auger Boring}

Sixty-three auger bores were mechanically excavated using a 12 -inch $(30.5-\mathrm{cm})$ auger bit. Overall, the auger placement and screening strategy were designed to (1) clarify the northwestern boundary of the site; (2) clarify the spatial distribution of the two components within the site; and (3) identify deposits that may be impacted by the construction of the outflow pipe as well as the water well and associated piping. Auger tests were excavated to a depth of $80 \mathrm{cmbs}$ to establish the presence/absence and density of cultural deposits as well as to determine their horizontal distribution. Based on the survey findings, cultural material appeared to be distributed in two levels, with an upper zone $(0-40 \mathrm{cmbs})$ and a lower zone $(40-80 \mathrm{cmbs})$. Therefore, auger bores were excavated and screened in two sections, with the first being from 0-40 cmbs, effectively sampling the upper deposit, and the second from $40-80 \mathrm{cmbs}$, sampling the lower deposit. All sediments from these auger bores were screened through 1/4-inch mesh and all artifacts were returned to the CAR laboratory for processing and analysis. Based on the results of these initial auger bores, 16 additional auger bores were excavated, following a similar screening strategy. These were placed to clarify and better define deposits in areas of planned construction. Following the auger boring, the data was examined to determine the horizontal and vertical distribution of cultural materials and identify and prioritize areas for additional work, especially in the construction areas.

\section{Backhoe Trenching}

The purpose of the four backhoe trenches was to expose stratigraphic profiles and potential features. Furthermore, backhoe trenches were used to guide the positioning of subsequent hand-excavated test units. Backhoe trenches did not exceed ten meters in length, one meter in width, and were no more than one meter deep. Backhoe trenches were not excavated beyond one meter based on survey results which did not produce cultural material below $60 \mathrm{~cm}$. After the excavation of a backhoe trench, the project archaeologist entered the trench to examine the walls. Thereafter, a one-meter segment of one representative wall was profiled and photographed. Soil horizons were notes on profiles, and Munsell colors of each stratum were recorded.

\section{Test Units}

As a more fine-grained exploratory and documentation strategy, four 50-x-50-cm units were excavated. Each test unit was positioned off of one of the four backhoe trenches. The goal of these excavations was to recover detailed information on the vertical distribution of cultural materials. All test units were excavated in arbitrary $10-\mathrm{cm}$ levels and all matrix recovered during excavations was screened through $1 / 4$-inch mesh. The depth of the test units did not exceed $80 \mathrm{cmbs}$. All artifacts recovered were bagged and referenced to the appropriate provenience. Material collected was returned to the CAR laboratory for processing and analysis. Matrix samples (ca. 1.5 to 2 liters in size) were collected from each level of all four test units. These samples were water screened in the CAR laboratory to recover cultural and macro-botanical materials. 


\section{Laboratory Methods}

All cultural material collected during the work at 41BP678 was prepared and stored in accordance with federal regulation 36 CFR part 79, and in accordance with current guidelines of the Center for Archaeological Research. Artifacts processed in the CAR laboratory were washed, air-dried, and stored in archival-quality bags. Soil samples were taken from each level of each test unit and were water screened through nested screens that were $1 / 4$-inch and $1 / 16$-inch size mesh. Materials from the heavy and light fractions, respectively, were bagged separately with a tag that contained the provenience information. The soil amount that was water screened per sample varied from 1.5 to 2 liters. The collected items were examined for cultural material and faunal remains.

Acid-free labels were placed in all artifact bags with a provenience and corresponding lot number. Tools were labeled with permanent ink and covered by a clear coat of acrylic. In addition, a small sample of unmodified debitage from each lot was labeled with the appropriate provenience data. Artifacts were separated by class and stored in acid-free boxes. Boxes were labeled with standard labels. Field notes, forms, and drawings were placed in acid-free file folders. Photographs were placed in archival-quality sleeves. Documents and forms were printed on acid-free paper. A copy of the final report and all computer disks pertaining to the investigations were stored in archival folders and curated with the field notes and documents. Upon completion of the project all cultural materials and records will be permanently curated at the CAR facility. 
This page has been

redacted because it

contains restricted

information. 


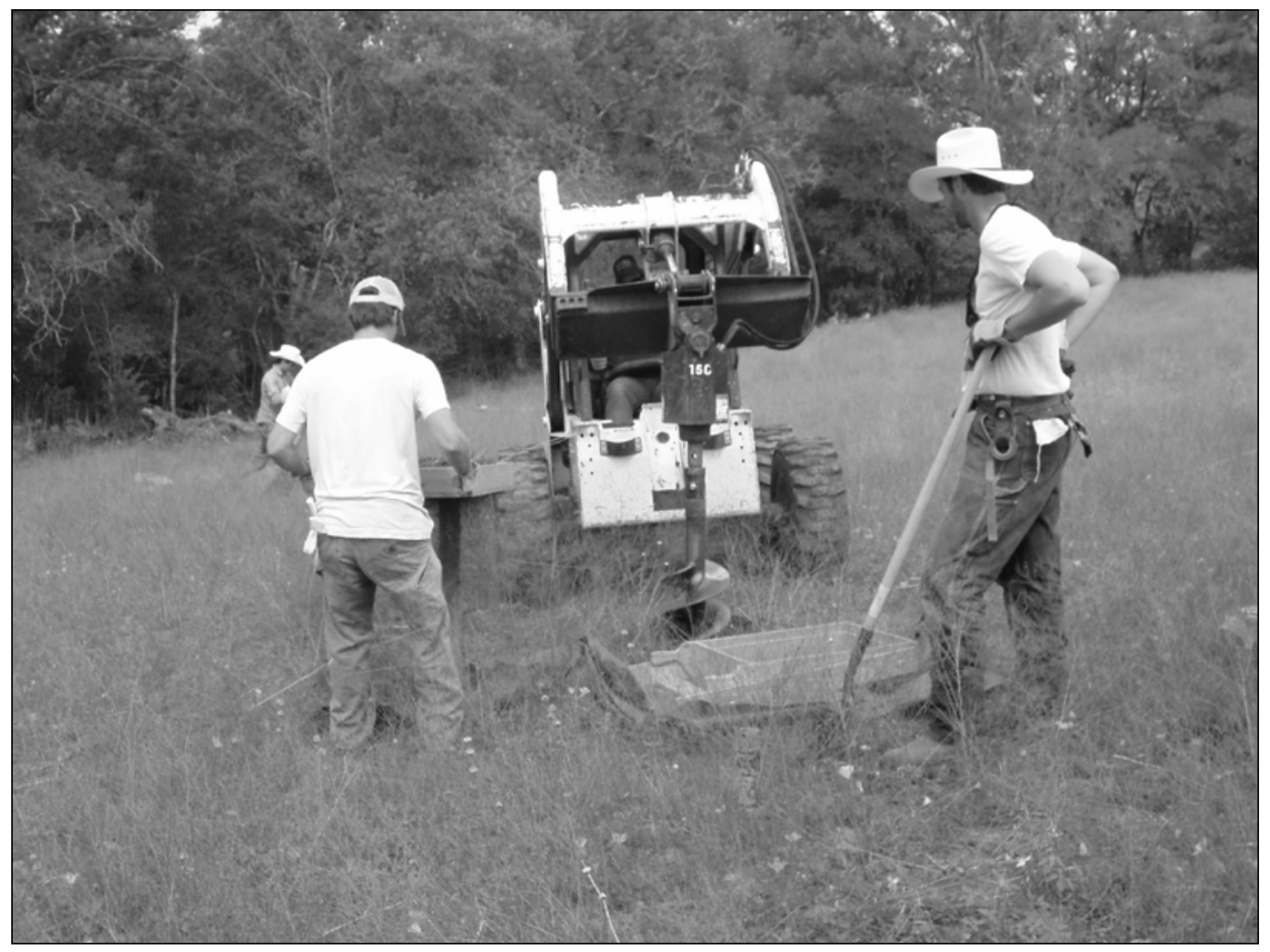

Figure 5-2. Mechanical auger testing along the northwestern portion of the site.

The amount of artifacts per level did not vary significantly. Fifty-one percent $(n=41)$ of the artifacts were recovered from Level $1(0-40 \mathrm{cmbs})$ and 49\% $(\mathrm{n}=40)$ were recovered from Level 2 (40-80 cmbs). Lithic debitage was the most frequent artifact type recovered from auger tests $(51 \%)$, followed by FCR and heat spalls (38\%), lithic tools $(5 \%)$, mussel shell umbos (4\%), and vertebrate faunal material (2\%). As illustrated in Figure 5-1, a majority of positive auger tests were on the eastern portion of the site, closest to the river bank.

\section{Backhoe Trenches}

Based in part on the results of the auger boring, four backhoe trenches were excavated. Backhoe trenches were placed in areas that would be potentially disturbed by pipe installations for the facility and in the vicinity of positive auger tests (see Figure 5-1). BHTs 1 and 2 were excavated on the northeast portion of the site, while BHTs 3 and 4 were placed in the south-central portion of the site. All backhoe trenches measured about $10 \mathrm{~m}$ in length, about one meter wide and did not exceed one meter in depth. Three of the four backhoe trenches (BHTs 1, 2 and 3) revealed homogenous soils that consisted of brown to dark brown silty clay. BHT 4 contained lighter soils and small amounts of calcium carbonate flecking. During the excavations of backhoe trenches no artifacts were identified nor were any features observed. Portions of BHTs 1 and 4 were drawn and photographed. BHT 1 consisted of three stratigraphic zones (Figure 5-3). The first zone was comprised of a brown (10YR 4/3 brown) organic horizon that extended from $0-5 \mathrm{cmbs}$. Zone 2 consisted of a silty clay matrix that was roughly $60 \mathrm{~cm}$ thick and reddish brown in color (10YR 5/4). The third zone contained higher clay content relative to Zones 1 and 2, and was reddish brown (5YR 5/3) in color. BHT 4 was located on the south-central

Table 5-1. Artifacts from Positive Auger Tests

\begin{tabular}{|l|c|c|c|}
\hline & Level 1 & Level 2 & Total \\
\hline Bone & 0 & 2 & 2 \\
\hline FCR/Heat Spalls & 13 & 18 & 31 \\
\hline Debitage & 24 & 17 & 41 \\
\hline Lithic Tools & 3 & 1 & 4 \\
\hline Mussel Shell & 1 & 2 & 3 \\
\hline Grand Total & $\mathbf{4 1}$ & $\mathbf{4 0}$ & $\mathbf{8 1}$ \\
\hline
\end{tabular}


portion of the site. Four distinct strata were identified in this backhoe trench (Figure 5-4). The upper zone was a loose organic matrix, brown in color (7.5 YR 5/3). The second layer was loose silty clay with roots. It was dark brown (7.5 YR 3/2). The matrix from the third zone had increased clay content and contained some mottling (7.5 YR 5/6). Calcium carbonate threads and nodules were present in the fourth strata, that continued to be a silty clay (7.5 YR 5/6). Artifacts were not observed in any of the walls of these four trenches and no cultural materials were noted in the backdirt piles.

\section{Test Units}

Following the excavation of the backhoe trenches, four 50-x-50-cm units were placed off the center of each backhoe trench (Figure 5-1). Each test unit was excavated to a depth of $80 \mathrm{cmbs}$, in $10-\mathrm{cm}$ increments. The terminal depth was established based on previous survey results (Moses 2004). The soils from Test Units (TUs) 1, 2, and 3 were generally homogenous and consisting of silty clays. TU 4 contained a clay matrix, with increasing calcium carbonate concentrations towards the bottom of the unit. A sparse amount of material was recovered from each test unit (Table 5-2).

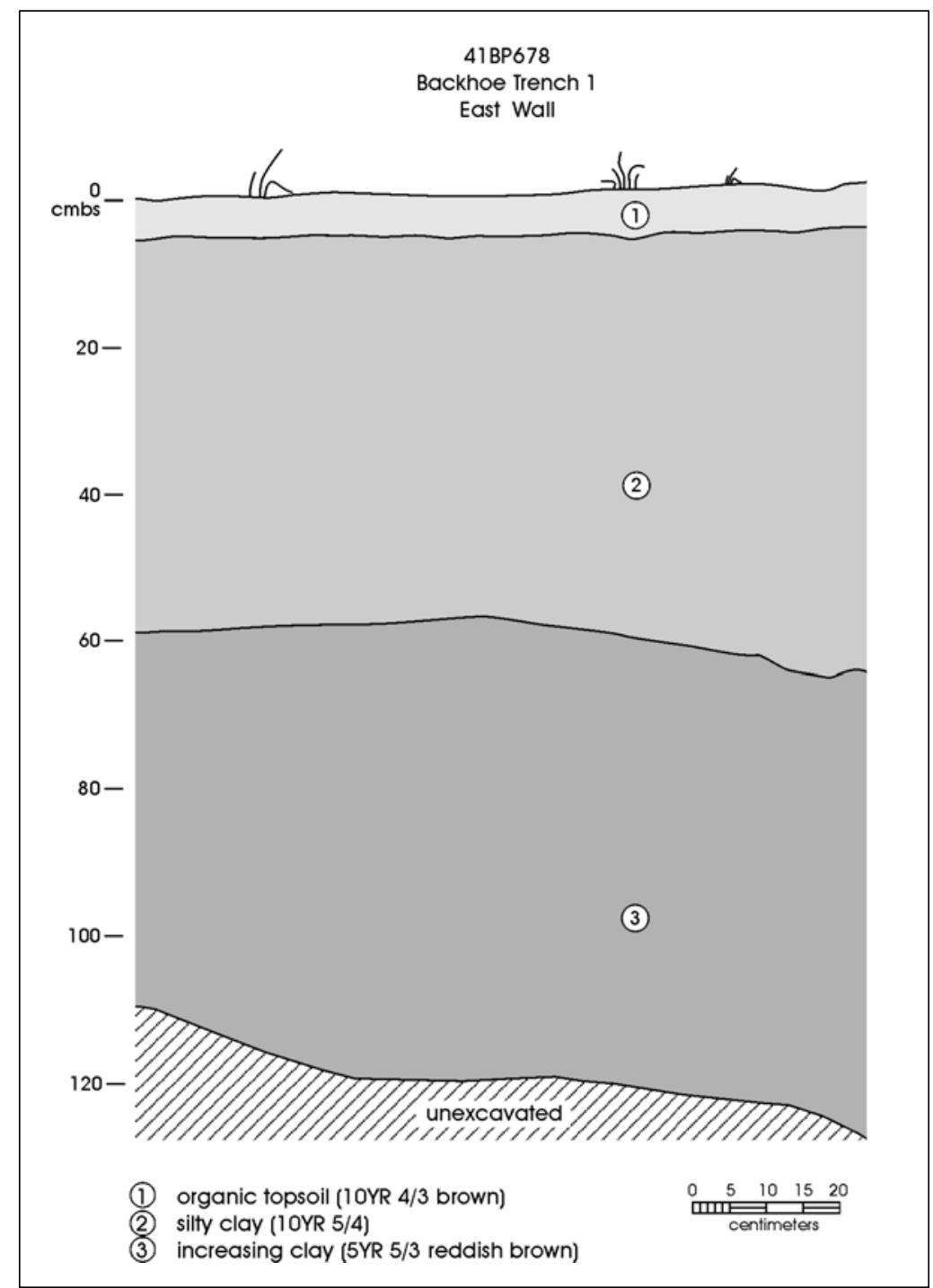

Figure 5-3. Profile of the east wall of Backhoe Trench 1. 


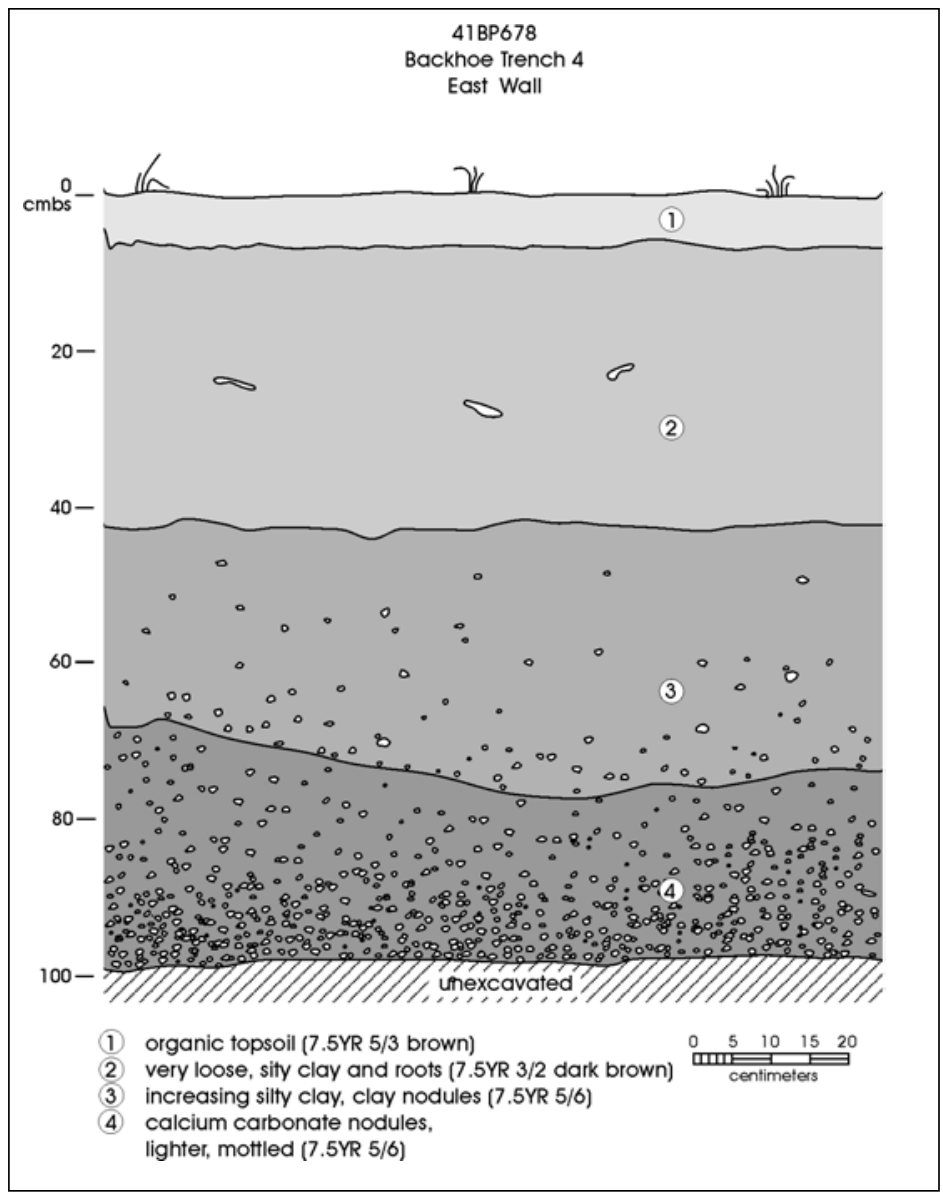

Figure 5-4. Profile of the east wall of Backhoe Trench 4.

The excavations of these units, in combination with an examination of the trench profiles, revealed that the upper 25 to $30 \mathrm{~cm}$ of deposits had been impacted by past plowing. No evidence of disturbance was noted in the deeper portions of the deposits in any of the trenches.

\section{Test Unit 1}

This test unit was located off BHT 1 on the east side of the trench (see Figure 5-1). The matrix from this test unit was silty clay, as described for BHT 1, Zone 2 (refer to Figure 5-3), becoming increasingly denser at lower depths. The silty clay matrix ranged from a brown (10YR 4/3) to a reddish brown (5YR 5/3) color (see Figure 5-5). The cultural material retrieved from this unit included Native American ceramics $(n=2)$ and debitage $(n=5)$. The highest density of artifacts was from Levels 1 and 4. Cultural material was less in Levels 5, 7 and 8 (Table 5-2). Snail shell fragments were present throughout the unit, but were not collected. Two Native American ceramic fragments were recovered from this unit in Level 4 (see Chapter 6 for descriptions). One sherd appeared to be a handle fragment. The second sherd was smaller and appeared to be a body sherd with characteristics similar to the larger sherd.

\section{Test Unit 2}

Test Unit 2 was positioned off BHT 2, on the west side of the trench (see Figure 5-1). This test unit contained a silty clay matrix similar that noted in TU 1 . The soil color ranged from a grayish brown (10YR 5/2) in Levels 1 through 4 to a dark yellowish brown (10YR 4/4) in the remaining levels. Cultural material was most frequent in Level $1(n=4)$ with few artifacts recovered from Levels 2, 5, 6, and 8 and no material recovered from the other levels (Table 5-2). Small calcium carbonates nodules and a few river pebbles were 
Table 5-2. Artifacts from Test Units

\begin{tabular}{|c|c|c|c|c|c|c|c|}
\hline Test Unit & Level & Bone & $\begin{array}{c}\text { FCR/ } \\
\text { Heat Spalls }\end{array}$ & Ceramics & Debitage & Mussel Shell & Total \\
\hline \multirow{9}{*}{1} & 1 & 0 & 0 & 0 & 2 & 0 & 2 \\
\hline & 2 & 0 & 0 & 0 & 0 & 0 & 0 \\
\hline & 3 & $\overline{0}$ & $\overline{0}$ & $\overline{0}$ & $\overline{0}$ & $\overline{0}$ & 0 \\
\hline & 4 & 0 & 0 & 2 & $\overline{0}$ & $\overline{0}$ & 2 \\
\hline & 5 & 0 & 0 & 0 & 1 & 0 & 1 \\
\hline & 6 & 0 & 0 & 0 & 0 & 0 & 0 \\
\hline & 7 & 0 & 0 & 0 & 1 & 0 & 1 \\
\hline & 8 & 0 & 0 & 0 & 1 & 0 & 1 \\
\hline & Total & 0 & $\overline{0}$ & 2 & 5 & $\overline{0}$ & $\overline{7}$ \\
\hline \multirow{9}{*}{2} & 1 & 0 & 3 & 0 & 1 & 0 & 4 \\
\hline & 2 & 0 & 0 & 0 & 0 & 1 & 1 \\
\hline & 3 & 0 & 0 & 0 & 0 & 0 & 0 \\
\hline & 4 & 0 & 0 & 0 & 0 & 0 & 0 \\
\hline & 5 & $\overline{0}$ & 1 & $\overline{0}$ & $\overline{0}$ & $\overline{0}$ & 1 \\
\hline & 6 & $\overline{0}$ & 1 & $\overline{0}$ & $\overline{0}$ & $\overline{0}$ & 1 \\
\hline & 7 & 0 & 0 & 0 & 0 & 0 & 0 \\
\hline & 8 & 0 & 0 & $\overline{0}$ & 1 & 0 & 1 \\
\hline & Total & $\mathbf{0}$ & 5 & $\overline{0}$ & 2 & 1 & $\overline{8}$ \\
\hline \multirow{9}{*}{3} & 1 & 1 & 0 & 0 & 0 & 0 & 1 \\
\hline & 2 & 0 & 0 & 0 & 0 & 0 & 0 \\
\hline & 3 & 0 & 0 & 0 & 0 & 0 & 0 \\
\hline & 4 & 0 & 0 & 0 & 0 & 0 & 0 \\
\hline & 5 & 0 & 2 & 0 & 0 & 0 & 2 \\
\hline & 6 & 0 & 0 & 0 & 0 & 0 & 0 \\
\hline & 7 & 0 & 0 & 0 & 1 & 0 & 1 \\
\hline & 8 & 0 & 0 & 0 & 0 & 0 & 0 \\
\hline & Total & 1 & 2 & $\overline{0}$ & 1 & $\overline{0}$ & $\overline{4}$ \\
\hline \multirow{9}{*}{4} & 1 & 0 & 0 & 0 & 0 & 0 & 0 \\
\hline & 2 & 0 & $\overline{0}$ & $\overline{5}$ & 2 & 0 & 7 \\
\hline & 3 & $\overline{0}$ & 1 & $\overline{0}$ & 1 & 0 & 2 \\
\hline & 4 & 0 & 0 & $\overline{0}$ & $\overline{0}$ & $\overline{0}$ & $\overline{0}$ \\
\hline & 5 & 0 & 0 & $\overline{0}$ & 1 & $\overline{0}$ & 1 \\
\hline & 6 & 0 & 0 & 0 & 1 & 0 & 1 \\
\hline & 7 & 0 & 1 & 0 & 0 & 0 & 1 \\
\hline & 8 & 0 & 0 & 0 & 0 & 0 & 0 \\
\hline & Total & 0 & 2 & 5 & 5 & 0 & 12 \\
\hline \multicolumn{2}{|c|}{ Grand Total } & 1 & 9 & 7 & 13 & $\mathbf{1}$ & 31 \\
\hline
\end{tabular}


present in Level 2. One mussel shell umbo was present in Level 2 and shell fragments were present in Level 4. FCR and heat spalls were present in Levels 5 and 6. Snail shell was not present in this test unit.

\section{Test Unit 3}

Test Unit 3 was located on the east side of BHT 3 (see Figure 5-1). Sediment in this test unit consisted of dark brown (10 YR 3/3) silty clay, which remained consistent throughout the unit, becoming denser at greater depths. Four artifacts were recovered from this unit. We collected cultural material from Levels 1, 5 and 7, with Level 5 containing two artifacts (Table 5-2). Snail shell fragments were present in Levels 3-7.

\section{Test Unit 4}

Test Unit 4 was excavated off the west wall of BHT 4 (see Figure 5-1). Sediment in this unit was silty clay. Soil colors ranged from a dark yellowish brown to a dark brown in Levels 6 through 8. These levels also contained high concentrations of calcium carbonate nodules (Figure 5-6). The 12 artifacts recovered from TU 4 represented the highest recovery rate of any of the units (Table 5-2). FCR, heat spalls and debitage, though sparse, were consistently present through Level 7. The highest frequency of material was recovered from Level 2 with five ceramic sherds and two pieces of debitage. The five ceramics sherds present in Level 2 are Native American (see Chapter 6 for descriptions). Small quantities of snail shell were present throughout the test unit, though none was collected.

\section{Water Screen Recovery}

Soil samples were taken from each level of each test unit (approximately 1.5 to 2 liters) and water screened through nested screens that were $1 / 4$-inch and 1/16-inch mesh. Materials were recovered from the water screening from TUs 1, 2 and 4 (Table 5-3). Most recovery was from the 1/16-inch mesh, with only one piece of FCR recovered from the 1/4-inch screen (Table 5-3). Water screening samples gave us an opportunity for collecting botanical remains and micro-lithics that would have been lost in the $1 / 4$-inch dry screening. Water screening of the clay soils also allowed us to assess the recovery rate of artifacts in the $1 / 4$-inch screening process. The low recovery rate in the $1 / 16$-inch recovery suggests the $1 / 4$-inch screening was a sufficient method.

\section{Summary}

The testing phase of 41BP678 used auger boring, backhoe trenching and hand-excavated test units to better define the vertical and horizontal distribution of cultural material. Auger testing yielded information that was used to redefine the site boundary. The northern boundary of the site was shifted slightly to the south. The eastern and southern boundaries remained defined by the landform, and the western boundary was moved in toward the east. Site 41BP678 now covers roughly 3.24 acres. The four backhoe trenches excavated on the site failed to located anticipated features or artifact concentrations.

Thirty-one artifacts were recovered from test unit excavations. Test Unit 4 produced the majority of the artifacts $(39 \%)$ recovered during hand excavation. Considering all test units, Levels 1 and 2 contained the highest frequencies of recovery (Figure 5-7). Artifact frequency declined in Levels 3 and 4 and increased in Level 5. Though low in frequency, Levels 6, 7, and 8 continued to produce artifacts. While based on a small sample size, Figure 5-7 reveals a bimodal distribution of cultural material that may indicate a multi-component site. Level 1 and Level 4 (TU 1 and TU 4) yielded prehistoric Native ceramics, suggesting that the upper mode dates to the Late Prehistoric period. The temporal association of the deeper deposits is unknown. The distributions of materials recovered from water screening are mimicking the trend produced by the 1/4-inch recovery (see Figure 5-7).

Overall, the testing efforts revealed a low density of artifacts at 41BP678. Test units recovered 38.75 artifacts per cubic meter of screened sediment. That recovery rate was substantially higher than auger tests (17.6 artifacts per cubic meter). Rather than implicating the recovery methods, this difference probably results from the fact that backhoe trenches, and their associated test units, were placed in the vicinity of positive auger tests. Conversely, auger bores were more widely distributed. The goals of the augering were to define site boundaries and identify higher density areas in which backhoe trenches and test units could be placed.

While overall artifact recovery was low, the vertical distribution of artifacts shows a bimodal pattern. The upper mode can be assigned to the Late Prehistoric based on the presence of ceramics. The lower mode cannot be assigned to a temporal period. Although testing failed to encounter 


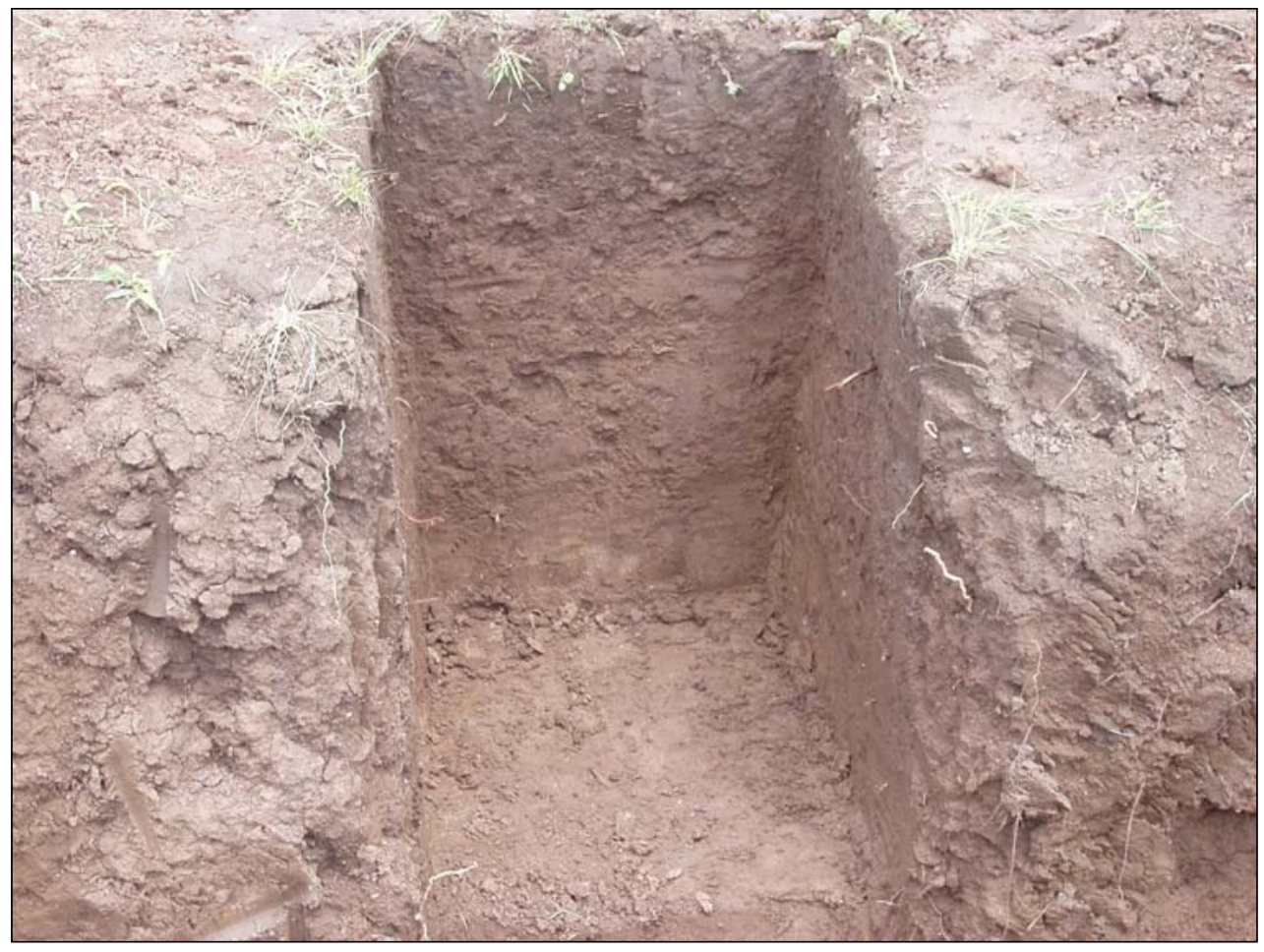

Figure 5-5. Photograph of Test Unit 1 east wall profile, at $80 \mathrm{cmbs}$.

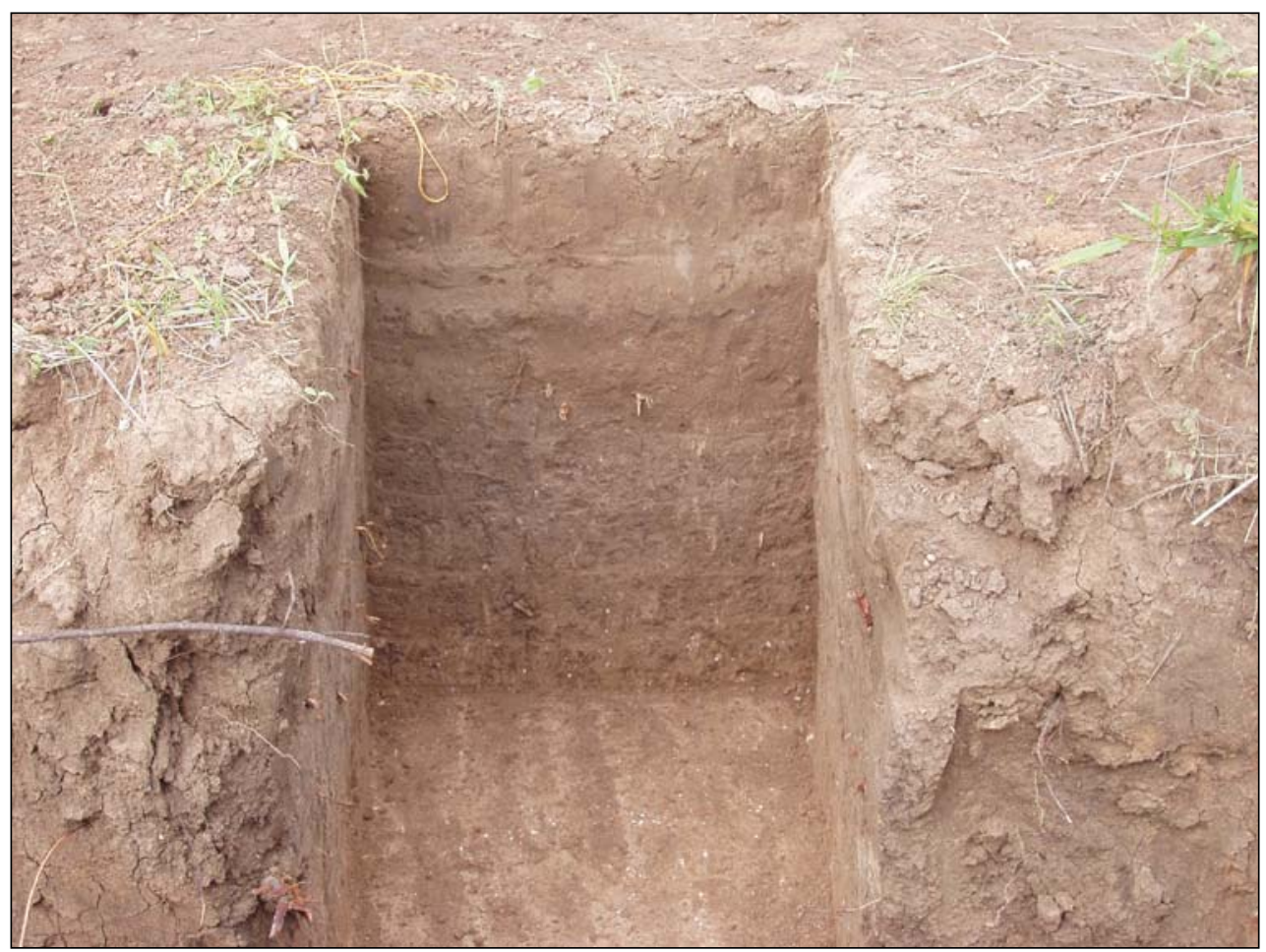

Figure 5-6. Photograph of Test Unit 4 west wall profile, at $80 \mathrm{cmbs}$. 
Table 5-3. Material Recovered from Water Screening

\begin{tabular}{|c|c|c|c|c|c|c|}
\hline \multirow[t]{2}{*}{ Test Unit } & \multirow[t]{2}{*}{ Level } & \multirow{2}{*}{\begin{tabular}{|l|} 
Bone \\
$1 / 16^{\prime \prime}$ \\
\end{tabular}} & \multirow{2}{*}{\begin{tabular}{|l|} 
Debitage \\
$1 / 16^{\prime \prime}$ \\
\end{tabular}} & \multicolumn{2}{|c|}{ Fire-cracked Rock } & \multirow[t]{2}{*}{ Total } \\
\hline & & & & \begin{tabular}{|l|l|}
$1 / 16^{\prime \prime}$ \\
\end{tabular} & $1 / 4 "$ & \\
\hline 1 & 8 & 1 & & & & 1 \\
\hline \multirow[t]{2}{*}{2} & 1 & & 2 & & & 2 \\
\hline & 6 & & & 1 & & 1 \\
\hline \multirow[t]{2}{*}{4} & 2 & & 1 & & & 1 \\
\hline & 7 & & & & 1 & 1 \\
\hline \multicolumn{2}{|c|}{ Grand Total } & 1 & 3 & 1 & 1 & 6 \\
\hline
\end{tabular}

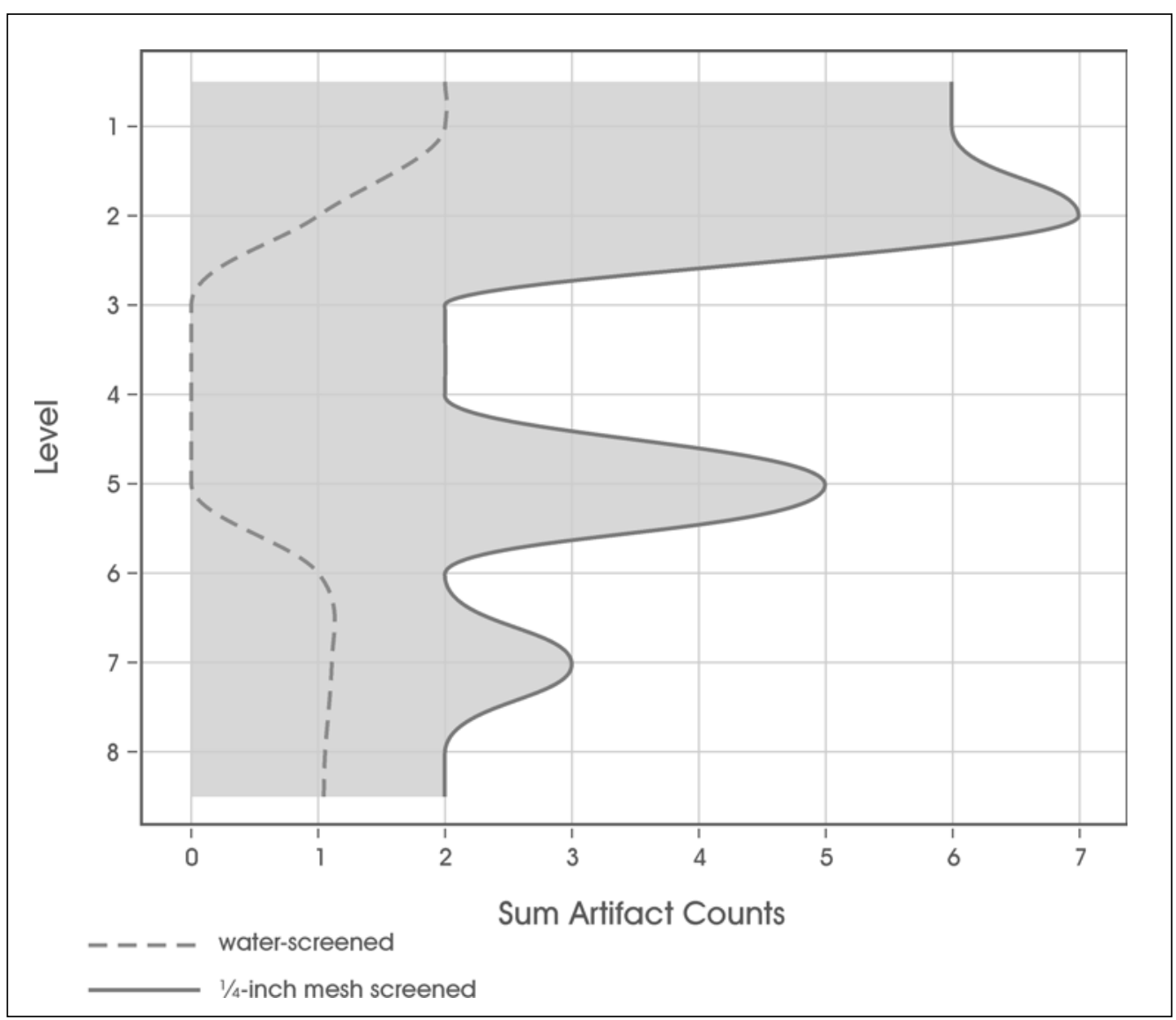

Figure 5-7. Vertical distribution of all artifacts from test units at $41 B P 678$.

any features or charcoal, burned rock was present at various depths. This suggests that thermal features were probably in use at 41BP678. We have no information, however, on the location or current condition of these features. 


\section{Chapter 6: Artifact Descriptions and Analyses}

The Phase II testing at 41BP678 recovered debitage, burned rock (heat spalls and FCR), lithic tools and ceramics. A small amount of faunal material was encountered that consisted of bone and mussel shell. This chapter presents the artifacts retrieved from testing efforts along with the results of analyses conducted on the artifacts. A detailed debitage analysis is presented, followed by discussions of the lithic tools, burned rock and ceramics.

\section{Debitage}

Debitage was the most frequent artifact type recovered from 41BP678. Fifty-four pieces of debitage were collected from auger tests $(n=41)$ and test units $(n=13)$. Debitage considered in the analysis included flakes and angular debris. There has been a great deal of research addressing debitage analysis, particularly on the methodology of characterizing and interpreting of debitage assemblages (see Andrefsky 1998; Sullivan and Rozen 1985; Mauldin and Amick 1989). Debitage attributes in this analysis include estimates of cortex, measures of thickness and length, the presence/absence of heat treatment and patina, and breakage patterns. The following discussion of the debitage analysis is organized by attribute.

\section{Cortex}

The foremost assumption when it comes to the amount of cortex on a piece of debitage is how it relates to reduction processes (Andrefsky 1998). Flake types are typically assigned as primary, secondary or tertiary, based on the amount of cortex, and thereafter, conjectures on reduction stages are made. It is expected that the amount of cortex should be less on late reduction specimens and greater on early reduction pieces. An additional factor that affects the presence of cortex on a specimen is raw material size. Andrefsky notes that debitage produced from cobbles with complete cortical surfaces will produce flakes with a greater amount of dorsal cortex (1989:109). If there is stress on raw material availability, there will be noticeable variability in the reduction stage processes (Magne 1989). High amounts of cortex will be typically found with pebble-based material (Magne 1989:19). The cortex percentages on an individual flake are likely related to both reduction processes and raw material size. For instance, current research investigating cortex percentage and raw material availability infers that sites in areas of low raw material availability have a low percentage of tertiary flakes, while sites in areas in with greater raw material availability have a higher percentage of tertiary flakes (Mauldin and Figueroa 2005).

In this analysis, cortex was measured on a piece of debitage by percentage. A specimen was noted as having $0 \%$, $1-25 \%, 26-50 \%, 51-75 \%, 76-99 \%$, or $100 \%$. It proved helpful in later stages of the analysis to combine percentages as follows (Table 6-1): (1) $0 \%$, (2) $1-50 \%$, and (3) $51-100 \%$. Fifty-four percent of the debitage sample has no cortex (tertiary), while $28 \%$ have $1-50 \%$ cortex and $19 \%$ have $51-100 \%$ cortex. Comparing cortex percentage between the two components revealed no significant differences.

Table 6-1. Cortex Percentages Displayed for Upper and Lower Components of 41BP678

\begin{tabular}{|l|r|r|r|}
\hline & \multicolumn{1}{|c|}{$\begin{array}{c}\text { Upper } \\
\text { Component }\end{array}$} & $\begin{array}{c}\text { Lower } \\
\text { Component }\end{array}$ & Total \\
\hline No cortex & 14 & 15 & 29 \\
\hline $1-50 \%$ & 11 & 4 & 15 \\
\hline $51-100 \%$ & 6 & 4 & 10 \\
\hline Grand Total & $\mathbf{3 1}$ & $\mathbf{2 3}$ & $\mathbf{5 4}$ \\
\hline
\end{tabular}

Based on patterns identified by Mauldin and Figueroa (2005), the percentage (54\%) of tertiary flakes at 41BP678 appears to correlate with low to medium areas of raw material availability (refer to Figure 2-1 and Figure 6-1). The small sample size could account for the difference between the 41BP678 data and the assemblages used in the original data.

\section{Midpoint Thickness}

Much like cortex amount, thickness of a lithic specimen can be an indicator of the reduction process. Thicker pieces of debitage are correlated to early reduction process, while thinner flakes may occur more often later in the reduction process. Ideally, debitage should get smaller as the end product gets closer to being complete (Andrefsky 1998:96). 

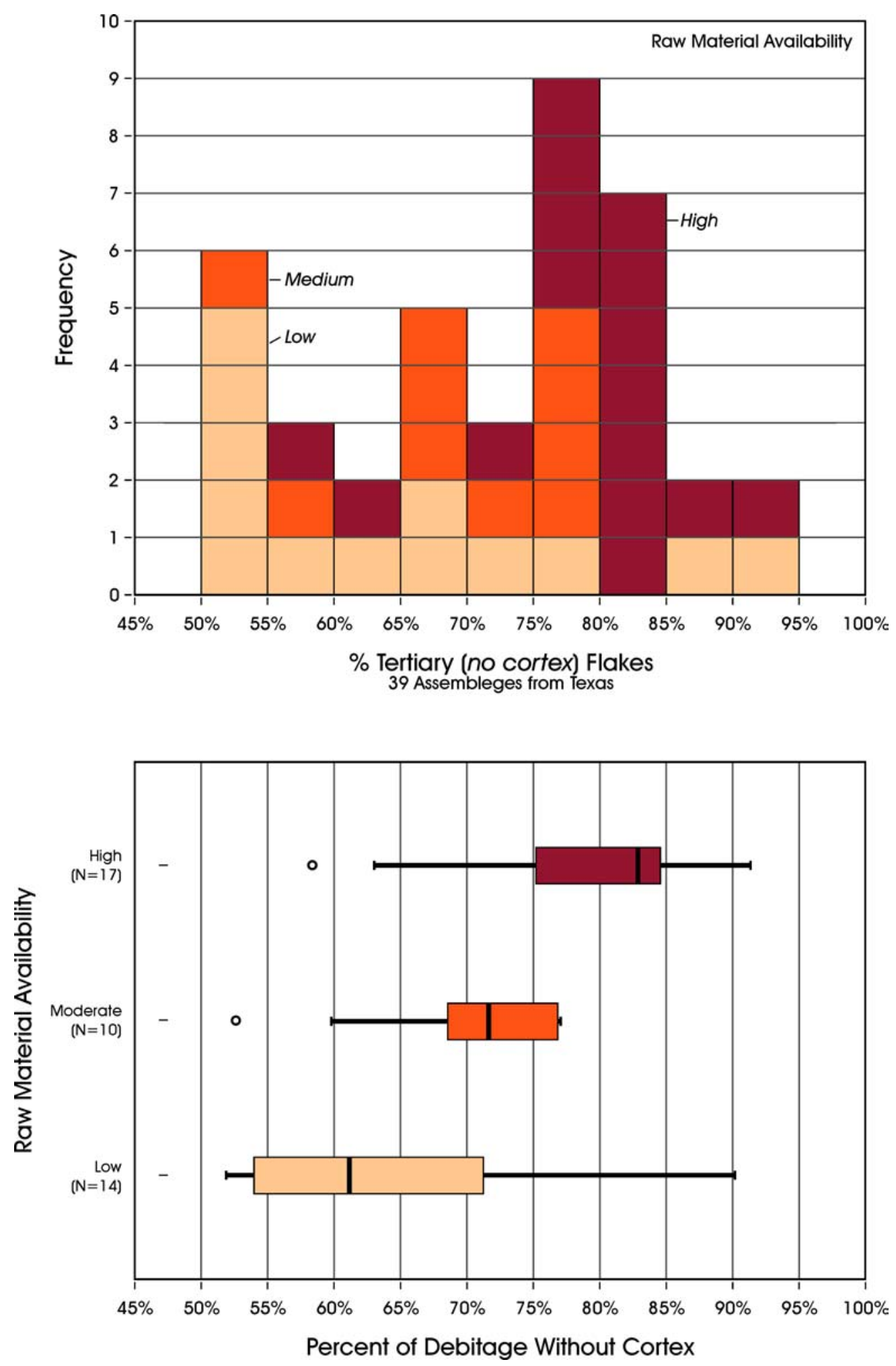

Figure 6-1. Percentage of tertiary flakes of 39 assemblages from Texas. 
Debitage thickness is the distance from the dorsal side to the ventral side (Andrefsky 1998) and the placement of the measurement can vary. The most common way to measure thickness is the maximum thickness on the specimen. Measurements can also be taken at various points along the length of the flake and at the bulb of force (Andrefsky 1998:99). For this analysis the midpoint thickness was measured. The mean thickness for the sample of 54 flakes was $4.4 \mathrm{~mm}$. When comparing thickness to cortex percentages, it appears that specimens without cortex are relatively thin (mean=3.3 mm). Specimens with $1-50 \%$ $($ mean $=5.4)$ and $51-100 \%($ mean $=6.0)$ cortex are relatively similar in thickness. However, the data support the notion that specimens with less cortex are thinner while those with more cortex are, on average, thicker. Comparing midpoint thickness between the two components of the site failed to reveal any significant differences.

\section{Maximum Length}

The maximum length of each specimen was recorded. The measurement was not always taken from the proximal to distal end, but rather the maximum dimension of the specimen was recorded. Similar to thickness measurements, the length of a specimen should be indicative of reduction processes and as noted earlier, the shorter the piece of debitage the closer to completion the end product is assumed to be. Overall, the mean maximum length for the entire sample was $23.3 \mathrm{~mm}$. Debitage pieces that were longer tended have more cortex than shorter pieces.

Specimens were grouped into two length categories $(<23 \mathrm{~mm}$ and $>23 \mathrm{~mm}$ ) determined by examining the mean maximum length of the specimens. A chi-square test of differences in cortex percentage by size group indicated a significant difference (Table 6-2; $\mathrm{X}^{2}=6.4, \mathrm{p}<.041, \mathrm{df}=2$ ).
Overall, specimens that were greater than $23 \mathrm{~mm}$ possessed more cortex than specimens less than $23 \mathrm{~mm}$. Adjusted residuals provide information on the contribution of each individual cell to the overall contingency table. Adjusted residual values exceeding an absolute value of 1.96 suggest that the cell differences are statistically significant at a .05 level of probability. As Table 6-2 shows, specimens with $51-100 \%$ cortex are over-represented in the $>23 \mathrm{~mm}$ size group.

Comparing the two deposits that are present on the site shows there are no differences in maximum length between the debitage collections. The size of the specimen and its correlation to cortex amount remained consistent as well between the upper and lower component. In this case the length of the specimen appears to correlate with the amount of cortex and supports the idea that larger specimens are derived from the early portion of reduction.

\section{Heat Treatment}

Each specimen was also examined for the presence or absence of heat treatment. Evidence of heat treating was indicated by a waxy appearance. The benefits of heat treating lithic material are reflected in the improved workability of the materials. Heat treating is typically conducted in later stages of reduction. Fifty-five percent of the debitage sample exhibited signs of heat treating, while the remaining $45 \%$ did not.

If one accepts the argument that heat treating will occur in the later stages of reduction, then debitage that is heat treated should be smaller and may have less cortex than specimens that are not heat treated. There was only a slight difference between the thickness of heat treated (mean $=4.1 \mathrm{~mm}$ ) and non-heat treated $(\mathrm{mean}=4.8 \mathrm{~mm})$ specimens. Results

Table 6-2. Size Grouping (above and below $23 \mathrm{~mm}$ ) and Cortex Percentages

\begin{tabular}{ll|r|r|r|}
\hline & & $<\mathbf{2 3} \mathbf{m m}$ & $>\mathbf{2 3} \mathbf{m m}$ & Total \\
\hline No cortex & Observed counts & 19 & 10 & 29 \\
& Adjusted residuals & 1.6 & -1.6 & \\
\hline $1-50 \%$ & Observed counts & 9 & 6 & 15 \\
& Adjusted residuals & 0.4 & -0.4 & \\
\hline $51-100 \%$ & Observed counts & 2 & 8 & 10 \\
& Adjusted residuals & $\mathbf{- 2 . 5}$ & $\mathbf{2 . 5}$ & \\
\hline Total & & $\mathbf{3 0}$ & $\mathbf{2 4}$ & $\mathbf{5 4}$ \\
Chi Square $=6.4$ \\
$\mathrm{p}<.041$ \\
$\mathrm{df}=2$
\end{tabular}


indicate that a majority of heat treated pieces do have cortex $(53 \%)$. The mean maximum length for heat treated pieces i

$22 \mathrm{~mm}$, while non-heat treated pieces are only slightly longer $(25 \mathrm{~mm})$. Therefore, heat treated pieces tended to contain cortex and appeared to be similar in size (i.e, length and thickness) when compared to non-heat treated specimens. As mentioned previously, the size of the raw material may be a contributing factor to these findings. The pattern may also reflect that the heating of the chert nodules may be the result of incidental contact with or exposure to fire rather than purposeful heat treating.

\section{Patina}

The presence and absence of patina was another attribute noted on debitage. The amount of patina on a piece of debitage has been used to infer age. It is typically inferred that the presence of patina is correlated with older materials. In several sites the occurrence of patinated material increases with depth (Frederick et al. 1994; Bement 1989), though the lack of patination on materials does not necessarily mean more recent deposition.

Thirty-seven percent of the debitage included in the analysis is patinated. The chi-square test proved to be significant
(Table 6-3; $\mathrm{X}^{2}=13.64, \mathrm{p}<.000, \mathrm{df}=1$ ) indicating that patinated materials tend to be more frequent in the deeper deposits $(40-80 \mathrm{cmbs})$.

When comparing the amount of patina and cortex percentages, $70 \%$ of patinated items have no cortex. A chisquare test illustrates there is a significant difference between patination and the amount of cortex on a specimen (Table 6-4; $\mathrm{X}^{2}=8.224, \mathrm{p}<.016, \mathrm{df}=2$ ). Patinated specimens tend to be less common among debitage with $1-50 \%$ cortex and among tertiary flakes.

\section{Breakage Patterns}

To examine the variation in breakage patterns within the assemblage from 41BP678, the condition of each specimen was recorded as being complete (CMP), platform remnant bearing (PRB), medial/distal fragment (MDF) or nonorientable fragment (NF). These categories were used during experimental archaeological research that was conducted to determine variation in breakage patterns between raw materials (Amick and Mauldin 1989). Though it seems that breakage patterns can be attributed to core or tool reduction activities (Sullivan and Rozen 1985), variability can also be due to differences in raw material type (Amick and Mauldin 1997). Another contributing

Table 6-3. Presence or Absence of Patina by Component

\begin{tabular}{|l|l|r|r|r|}
\hline & Uppper Component & Lower Component & \multicolumn{1}{c|}{ Total } \\
\hline No & Observed counts & 26 & 8 & 34 \\
\hline Yes & Observed counts & 5 & 15 & 20 \\
\hline Total & $\mathbf{3 1}$ & $\mathbf{2 3}$ & $\mathbf{5 4}$ \\
\hline
\end{tabular}

Chi Square $=13.64$

$\mathrm{p}<.000$

$\mathrm{df}=1$

Table 6-4. Patination and Cortex Percentage

\begin{tabular}{|ll|r|r|r|r|}
\hline & & No cortex & $\mathbf{1 - 5 0 \%}$ & $\mathbf{5 1 - 1 0 0 \%}$ & Total \\
\hline No & Observed counts & 15 & 14 & 5 & 34 \\
& Adjusted residuals & -1.8 & $\mathbf{2 . 9}$ & -0.9 & \\
\cline { 1 - 4 } Yes & Observed counts & 14 & 1 & 5 & 20 \\
& Adjusted residuals & 1.8 & $\mathbf{- 2 . 9}$ & 0.9 & \\
\hline Total & & $\mathbf{2 9}$ & $\mathbf{1 5}$ & $\mathbf{1 0}$ & $\mathbf{5 4}$ \\
\hline
\end{tabular}

Chi Square $=8.224$

$\mathrm{p}<.016$

$\mathrm{df}=2$ 
factor that may affect breakage patterns within a debitage assemblage is post-depositional trampling (Prentiss and Romanski 1989).

Results from the analysis of debitage from 41BP678 indicate that medial/distal flake fragments are the most common (44\%) followed by complete flakes (29.6\%; Table 6-5). Sullivan and Rozen (1985) would identify the assemblage as the product of tool manufacturing given the high percentage of broken fragments (medial/distal fragments). Breakage patterns within experimentally produced chert assemblages on the other hand, suggest an assemblage derived from core reduction (Amick and Mauldin 1997). Table 6-5 presents the difference in percentages derived from work conducted by Sullivan and Rozen (1985), Amick and Mauldin (1997) and Prentiss and Romanski (1989).

Based on these research results it appears that two different types of manufacturing assemblages are represented in the two components present on site (Figure 6-2). The upper component (0-40 cmbs) appears to have only slightly more medial/distal fragments versus complete flakes, while the lower component (40-80 cmbs) exhibits a significantly higher percentage of medial/distal fragments versus complete flakes. Comparing the two components to experimental assemblages (Figure 6-3; Amick and Mauldin 1997; Prentiss and Romanski 1989), it seems that the upper component is similar to an untrampled tool reduction assemblage. The lower component appears to be the product of core reduction.

The relationships between breakage patterns and cortex percentage, midpoint thickness, maximum length, heat treatment and patina by component are presented in Table 6-6. When considering the entire assemblage, cortex percentage according to breakage type varies. Complete flakes frequently have no cortex as do platform remnant bearing types. The mean midpoint thickness does not vary significantly between breakage types, while the mean maximum lengths vary slightly with non-orientable and platform remnant bearing specimens being thinner than complete flakes and medial/distal fragments. All of the breakage types show signs of heat treatment, with treatment being most common among complete flakes and medial distal fragments. Patina is most frequent on complete and medial/distal pieces.

The upper component $(0-40 \mathrm{cmbs})$ of the site does not exhibit any significant relationships between cortex percentage and breakage type (refer to Table 6-6). Examining breakage patterns by component reveals that the mean midpoint thickness does vary (platform remnant bearing $=3.6 \mathrm{~mm}$ ). The maximum length among types also varies with means for platform remnant bearing and nonorientable fragments being significantly lower than complete and medial/distal fragments. The box plots in Figure 6-4 display the medians and the upper and lower quartiles for midpoint thickness and maximum length. Similar to the overall pattern, heat treatment is most frequently seen on complete pieces and medial/distal fragments. Patina is evident on only five pieces in the upper component.

The debitage in the lower component, like the upper component, most frequently does not exhibit cortex. The midpoint thickness of types appears to increase in the lower component; with the exception of medial/distal fragments which are thinner $($ mean $=3.3 \mathrm{~mm})$. Similar patterns are seen in maximum length with an increase among the breakage types, excluding medial/distal fragments which

Table 6-5. Flake Fragement Percentages for Tool versus Core Reduction Assemblages

\begin{tabular}{|l|r|r|r|}
\hline & *Sullivan and Rozen (1985) & Amick and Mauldin (1997) & Prentice and Romansky (1989) \\
\hline Tool & & & \\
\hline CMP & 22 & 41.7 & 33 \\
\hline PRB & 17 & 19.6 & 26 \\
\hline MDF & 53 & 37.8 & 56 \\
\hline NF & 8 & 0.9 & 22 \\
\hline Core & & & 23 \\
\hline CMP & 65 & 35.6 & 24 \\
\hline PRB & 8 & 21.3 & 32 \\
\hline MDF & 20 & 40.7 & 2.3 \\
\hline NF & 7 & & \\
\hline
\end{tabular}

* Calculations adjusted for analytical categories 


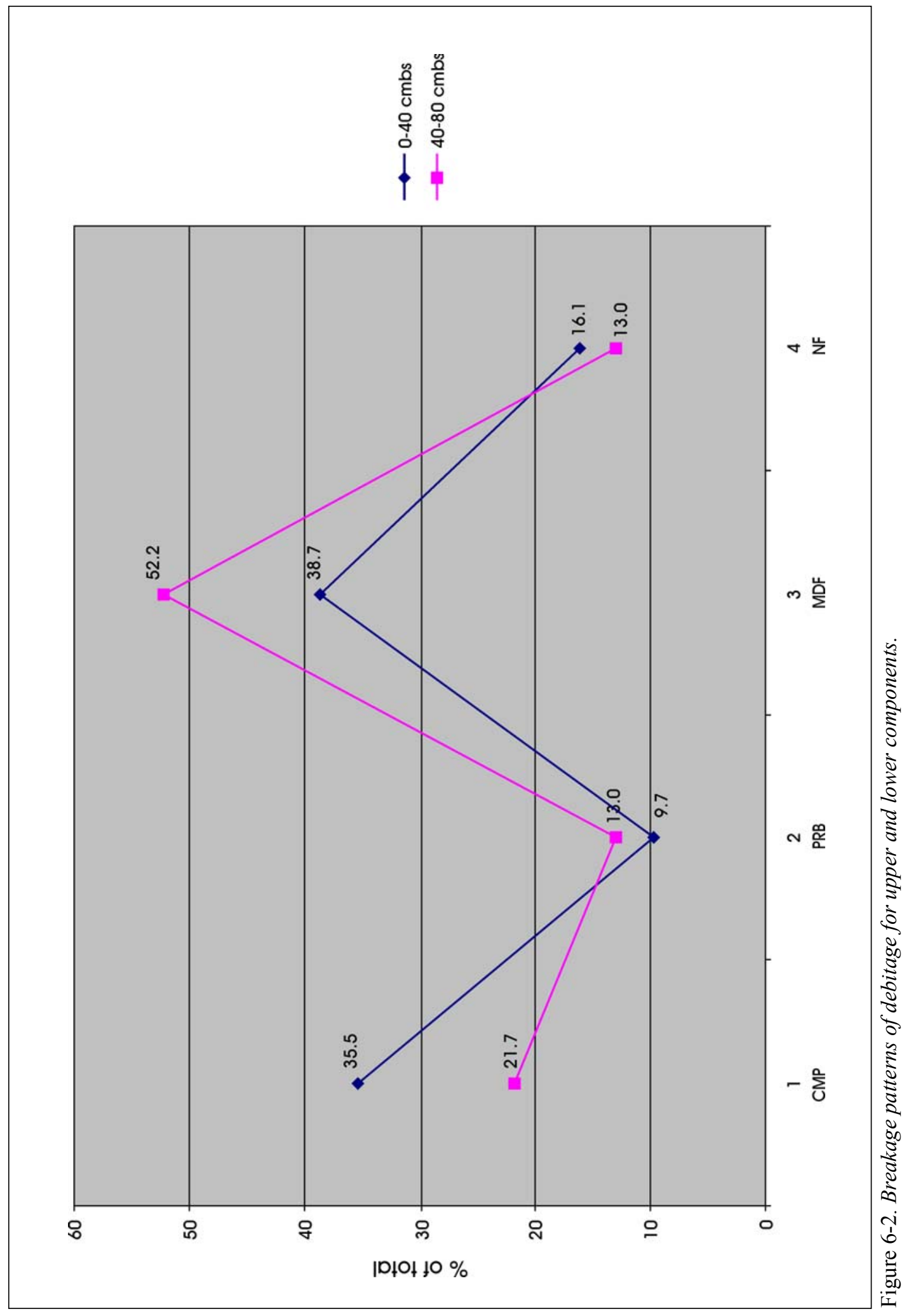




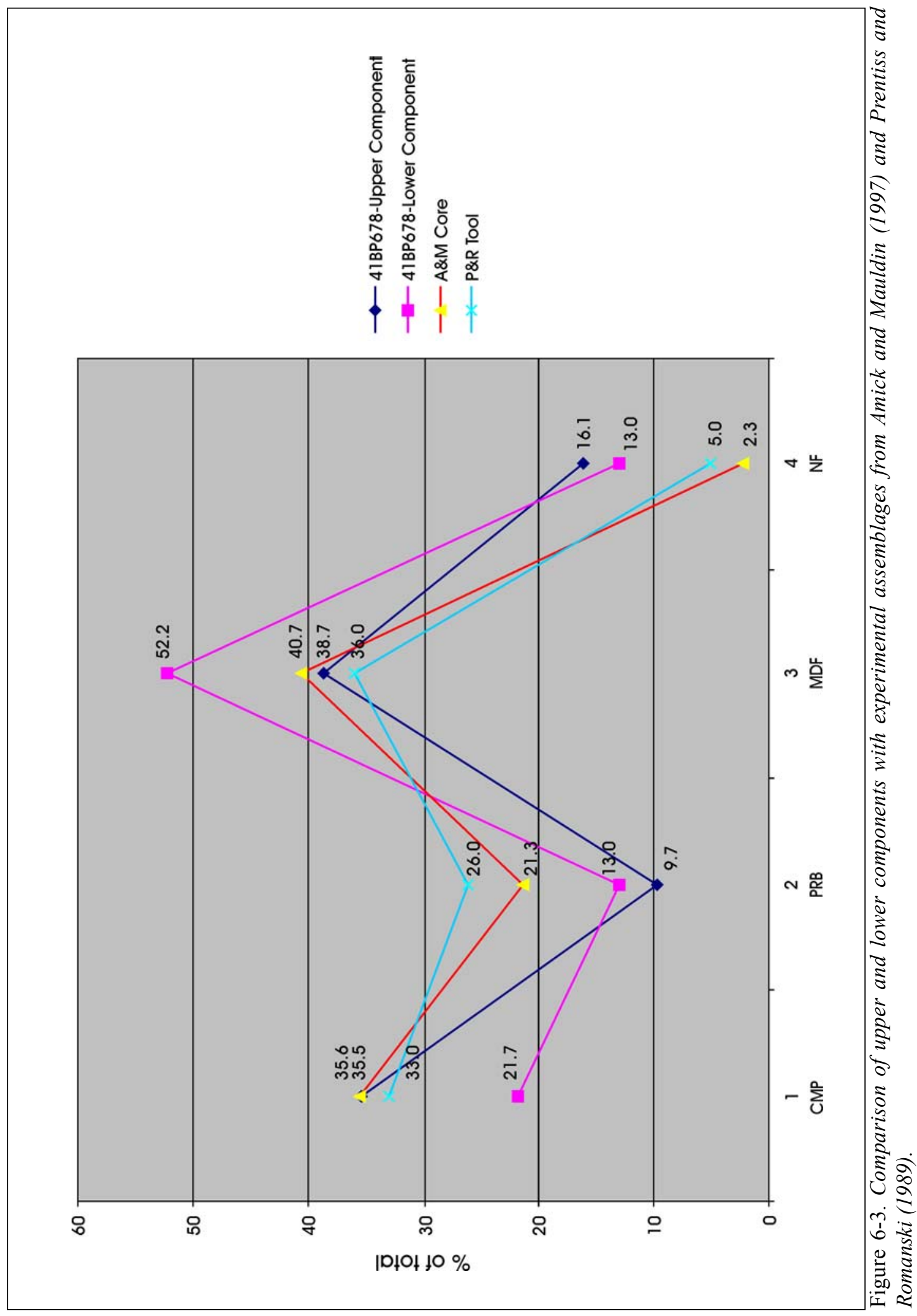


Table 6-6. Debitage Analysis Attributes According to Breakage Patterns

\begin{tabular}{|c|c|c|c|c|c|}
\hline Breakage Patterns & CMP & PRB & MDF & NF & Total \\
\hline Entire Sample & 16 & 6 & 24 & 8 & 54 \\
\hline \multicolumn{6}{|l|}{ Cortex \% } \\
\hline no cortex & 11 & 13 & 3 & 2 & 29 \\
\hline $1-50 \%$ & 4 & 6 & 3 & 2 & 15 \\
\hline $51-100 \%$ & 1 & 5 & 2 & 2 & 10 \\
\hline midpt. thickness minimum & 1 & 1 & 1 & 2 & \\
\hline mean midpt. Thickness & 4.3 & 4.3 & 4.4 & 4.6 & \\
\hline midpt. thickness maximum & 12 & 9 & 12 & 7 & \\
\hline maximum length minimum & 11 & 9 & 11 & 10 & \\
\hline mean maximum length & 23.4 & 21.6 & 24.9 & 19.71 & \\
\hline maximum length maximum & 43 & 33 & 42 & 44 & \\
\hline heat treated & 10 & 2 & 13 & 5 & 30 \\
\hline patina & 7 & 2 & 9 & 2 & 20 \\
\hline \multicolumn{6}{|l|}{ Upper Component } \\
\hline \multicolumn{6}{|l|}{ Cortex \% } \\
\hline no cortex & 6 & 1 & 4 & 3 & 14 \\
\hline $1-50 \%$ & 4 & 1 & 5 & 1 & 11 \\
\hline $51-100 \%$ & 1 & 1 & 3 & 1 & 6 \\
\hline midpt. thickness minimum & 1 & 2 & 2 & 3 & \\
\hline mean midpt. thickness & 4.2 & 3.6 & 5.4 & 4.2 & \\
\hline midpt. thickness maximum & 12 & 5 & 13 & 7 & \\
\hline maximum length minimum & 11 & 9 & 13 & 10 & \\
\hline mean maximum length & 22.1 & 19 & 27.1 & 18 & \\
\hline maximum length maximum & 43 & 27 & 44 & 30 & \\
\hline heat treated & 7 & 1 & 8 & 2 & 18 \\
\hline patina & 2 & 1 & 1 & 1 & 5 \\
\hline \multicolumn{6}{|l|}{ Lower Component } \\
\hline \multicolumn{6}{|l|}{ Cortex \% } \\
\hline no cortex & 5 & 1 & 9 & 0 & 15 \\
\hline $1-50 \%$ & 0 & 1 & 0 & 2 & 3 \\
\hline $51-100 \%$ & 0 & 1 & 2 & 1 & 4 \\
\hline midpt. thickness minimum & 3 & 1 & 2 & 5 & \\
\hline mean midpt. thickness & 4.5 & 5.1 & 3.3 & 5.4 & \\
\hline midpt. thickness maximum & 8 & 9 & 5 & 7 & \\
\hline maximum length minimum & 17 & 11 & 12 & 7 & \\
\hline mean maximum length & 26.5 & 24 & 22.6 & 22.7 & \\
\hline maximum length maximum & 32 & 33 & 31 & 44 & \\
\hline heat treated & 3 & 1 & 5 & 3 & 12 \\
\hline patina & 5 & 1 & 8 & 1 & 15 \\
\hline
\end{tabular}

* All measurements are in millimeters 


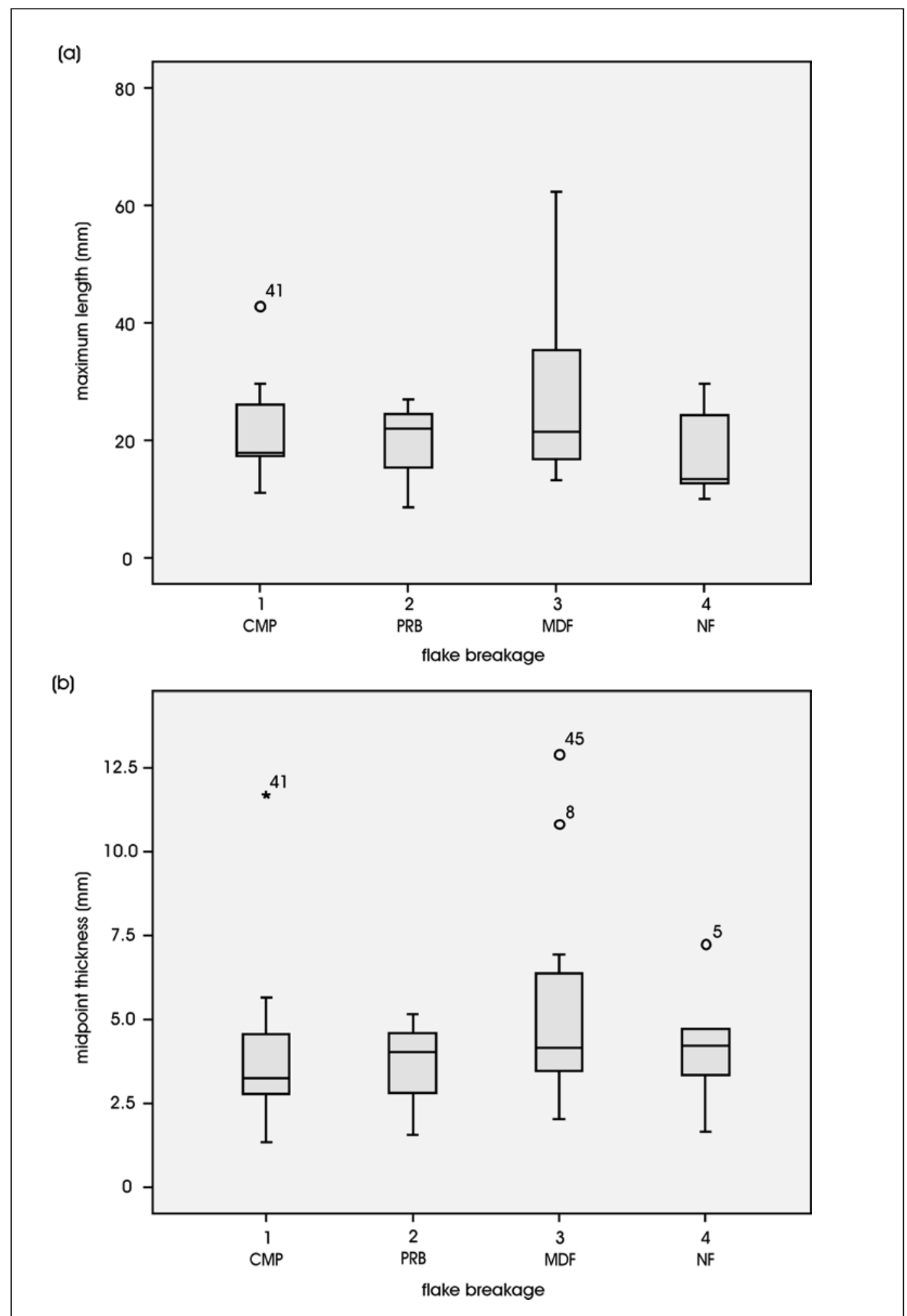

Figure 6-4. Boxplots comparing breakage patterns to (a) maximum length and (b) midpoint thickness in the upper component of $41 B P 678$. 


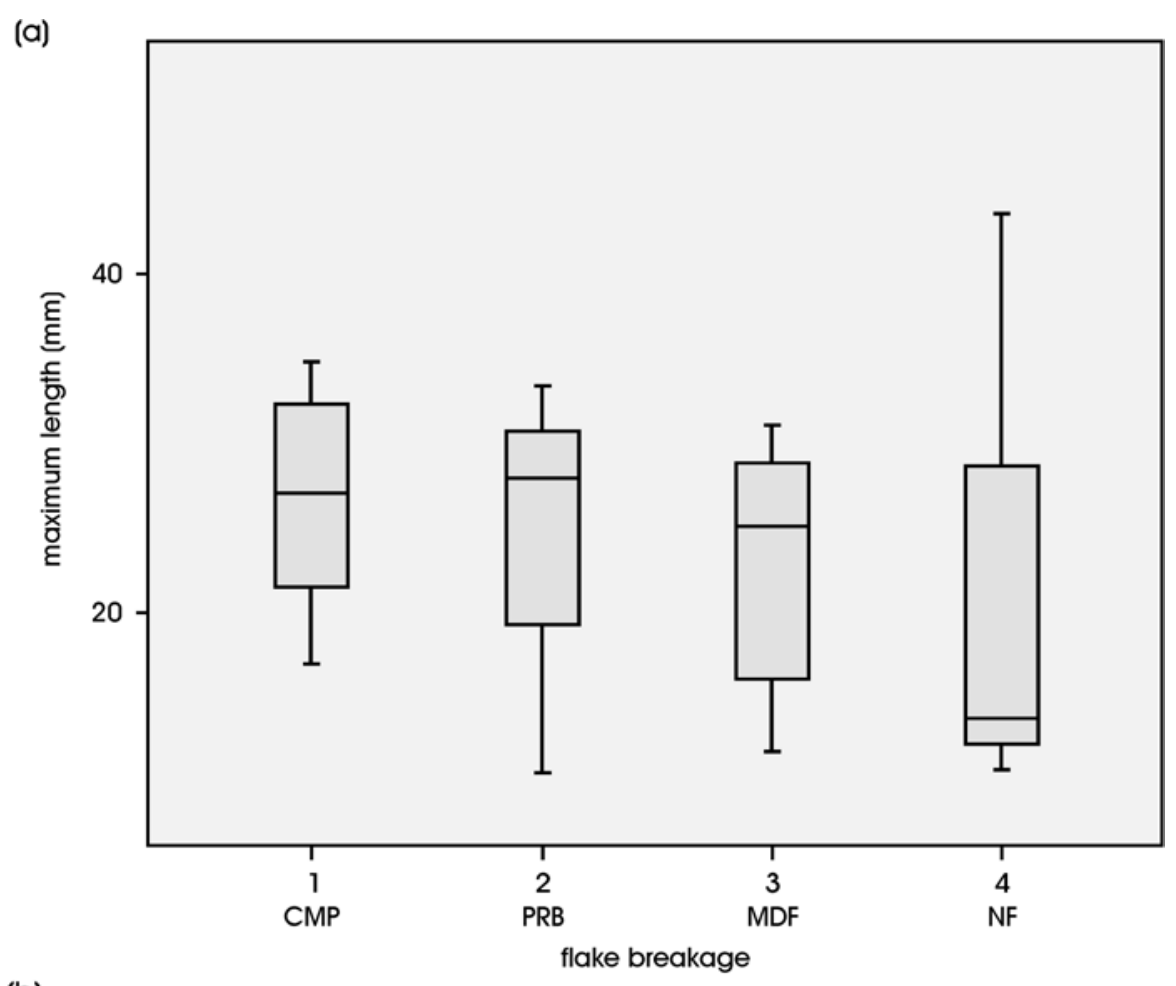

(b)

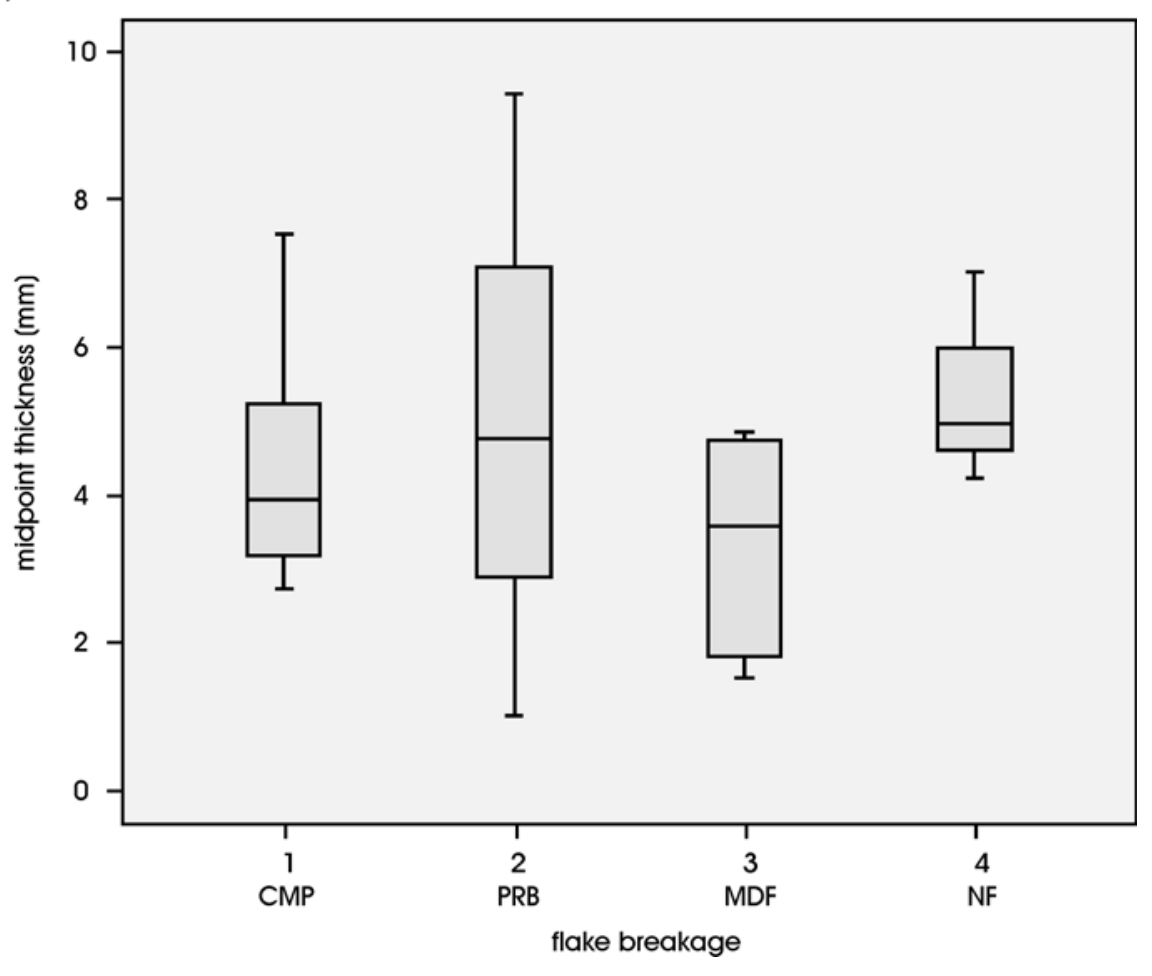

Figure 6-5. Boxplots comparing breakage patterns to (a) maximum length and (b) midpoint thickness in the lower component of $41 B P 678$. 
are smaller in the lower component (mean=22.6 mm). The box plots in Figure 6-5 exhibit the median and the upper and lower quartiles for midpoint thickness and maximum length. Heat treating is frequent on complete and medial/distal fragments. Patina occurs on complete and medial/distal flakes as well.

\section{Conclusions}

Typically, when debitage analysis is conducted the focus is on determining the stage of reduction reflected by the assemblage. It is assumed that the smaller the piece of debitage, both in terms of length and thickness, the more likely that it represents late stage reduction. Attributes such as cortex and heat treating also correspond to this linear trajectory are ascribed to early or late reduction stages. Factors such as raw material size and availability are secondary considerations in debitage variability. The debitage assemblage from the testing phase of 41BP678 exhibits a higher percentage of cortex than expected. Analytical categories such as midpoint thickness and maximum length do appear to indicate a late reduction process, with thicker and longer pieces exhibiting higher percentages of cortex.

The variation of breakage patterns apparent in the upper and lower component assemblage could be attributed to manufacturing differences in these two components. The dramatic differences between thickness and lengths when comparing breakage patterns of the two components suggests that Late Prehistoric lithic manufacturing (upper component) and those performed earlier in time (lower component) were quite different.

\section{A Comparison of Debitage Assemblages from 41BP678 and $41 \mathrm{BP} 679$}

This section compares the debitage assemblages from 41BP678 and 41BP679 (see Munoz 2006). Site 41BP679 is on the same land form as 41BP678 (less than $200 \mathrm{~m}$ to the west). There seem to be some significant differences between the two debitage assemblages.

Testing efforts at 41BP679 were identical with the excavation of auger tests, backhoe trenches and $50-\mathrm{x}-50-\mathrm{cm}$ test units . Excavations at 41BP678 recovered 54 pieces of debitage and 41BP679 produced 87 pieces. A slightly higher volume of dirt was removed from 41BP678 $\left(5.41 \mathrm{~m}^{3}\right)$ than
41BP679 $\left(5.32 \mathrm{~m}^{3}\right)$. Site 41BP679 has a higher density of debitage, with 16.3 pieces of debitage per cubic meter, compared to 10 pieces of debitage per cubic meter for 41BP678. Similar attributes were examined during the analysis of both debitage assemblages.

The maximum length and midpoint thickness of the debitage from the two sites did not differ significantly. The mean maximum length of specimens from $41 \mathrm{BP} 678$ is $23.3 \mathrm{~mm}$, while for 41BP679 it is $25.7 \mathrm{~mm}$. The mean thickness also does not differ much between site assemblages (41BP678: mean=4.4 mm; 41BP679: mean=4.6 mm).

There was a difference in cortex percentages that appears to be significant (Table 6-7: $\mathrm{X}^{2}=13.2, \mathrm{p}<.001, \mathrm{df}=2$ ), with 41BP679 having an over-representation of tertiary debitage compared to 41BP678 where corticated debitage with $51-100 \%$ cortex is over-represented. The number of heat treated and non-heat treated specimens between the sites proved to be significant as well (Table 6-8: $\mathrm{X}^{2}=9.17, \mathrm{p}<.002$, $\mathrm{df}=1)$. There were more heat treated specimens at $41 \mathrm{BP} 678$ compared to 41BP679. The amount of patinated versus non-patinated specimens differed significantly between the sites (Table 6-9: $\mathrm{X}^{2}=21.1, \mathrm{p}<.000, \mathrm{df}=1$ ). The breakage

Table 6-7. Cortex Percentage Comparisons between 41BP678 and 41BP679

\begin{tabular}{|l|r|r|r|}
\hline & \multicolumn{1}{|c|}{ 41 BP679 } & \multicolumn{1}{|l|}{ 11BP678 } & \multicolumn{1}{l|}{ Total } \\
\hline \multicolumn{1}{|c|}{0} & 61 & 29 & 90 \\
\hline Adjusted residuals & $\mathbf{2}$ & $\mathbf{- 2}$ & \\
\hline $1-50 \%$ & 24 & 14 & 38 \\
\hline Adjusted residuals & 0.2 & -0.2 & \\
\hline $51-100 \%$ & 2 & 11 & 13 \\
\hline Adjusted residuals & $\mathbf{- 3 . 6}$ & $\mathbf{3 . 6}$ & \\
\hline Total & \multicolumn{4}{|l}{} \\
\hline
\end{tabular}

Chi Square $=13.2$

$\mathrm{p}<.001$

$\mathrm{df}=2$

Table 6-8. Heat Treated Specimens from 41BP678 and 41BP679

\begin{tabular}{|l|r|r|r|}
\hline & 41BP679 & 41BP678 & Total \\
\hline No & 61 & 24 & 85 \\
\hline Adjusted residuals & 3 & -3 & \\
\hline Yes & 26 & 30 & 56 \\
\hline Adjusted residuals & -3 & 3 & \\
\hline Total & \multicolumn{4}{|l}{} \\
\hline
\end{tabular}

Chi Square $=9.171$

$\mathrm{p}<.002$

$\mathrm{df}=1$ 
Table 6-9. Patination of Specimens from 41BP678 and 41BP679

\begin{tabular}{|l|l|r|r|r|}
\hline & 41BP679 & 41BP678 & \multicolumn{1}{c|}{ Total } \\
\hline No & Observed counts & 21 & 34 & 55 \\
\hline & Adjusted residuals & -4.6 & 4.6 & \\
\hline Yes & Observed counts & 66 & 20 & 86 \\
\hline & Adjusted residuals & 4.6 & -4.6 & \\
\hline
\end{tabular}

Chi Square $=21.1$

$\mathrm{p}<.000$

$\mathrm{df}=1$

Table 6-10. Breakage Patterns among Debitage from 41BP678 and 41BP679

\begin{tabular}{l|l|r|r|r|r|}
\hline & CMP & PRB & MDF & NF & Total \\
\hline 41BP678-upper component & 11 & 3 & 12 & 5 & 31 \\
\hline Adjusted residuals & -0.5 & -0.6 & -0.5 & $\mathbf{2 . 8}$ & \\
\hline 41BP678-lower component & 5 & 3 & 12 & 3 & 23 \\
\hline Adjusted residuals & $-\mathbf{1 . 9}$ & 0 & 1 & 1.7 & \\
\hline 41BP679 & 39 & 12 & 36 & 0 & 87 \\
\hline Adjusted residuals & 1.8 & 0.5 & -0.4 & $\mathbf{- 3 . 7}$ & \\
\hline Total & \multicolumn{7}{|l|}{} \\
Chi Square $=16.6$ \\
$\begin{array}{l}\text { p }<.011 \\
\text { df }=6\end{array}$
\end{tabular}

patterns between the 41BP678 (upper and lower components) and the 41BP679 debitage assemblages proved significant (Table 6-10: $\mathrm{X}^{2}=16.6, \mathrm{p}<.011, \mathrm{df}=6$ ) with a lower number of non-orientable fragments in the 41BP679 assemblage than expected.

Site 41BP679 has a slight over-representation of complete flakes. A comparison was made of the two assemblages to experimental assemblages (Amick and Mauldin 1997; Prentiss and Romanski 1987; Figure 6-6). The 41BP678 upper component assemblage is similar to Prentiss and Romanski's untrampled tool reduction assemblage (Figure 6-7), while the lower component is quite similar to Amick and Mauldin's core reduction assemblage. The 41BP679 debitage assemblage appears to be similar to Amick and Mauldin's tool assemblage. Data from 41CW92, in nearby Caldwell County was also plotted against the Bastrop County data as a comparison (Figure 6-8), revealing an assemblage resembling Amick and Mauldin's core reduction assemblage (Houk et al. 2005). These data suggest that different tool manufacture and/or raw material reduction strategies may have occurred within the two components of 41BP678 when compared to 41BP679.

\section{Lithic Tools}

As the case with debitage analysis, lithic tools are typically discussed in terms of reduction processes (i.e., early, middle or late reduction). Large tool assemblages could provide information about site function. Lithic tools encountered at 41BP678 were few; they included two bifaces, one cobble tool and one edge-modified flake recovered from auger testing. The cobble tool measured $66.57 \mathrm{~mm}$ in length, $38.51 \mathrm{~mm}$ thick and weighed $304 \mathrm{~g}$ (Figure 6-9). It contained about $51-75 \%$ cortex concentrated opposite a bifacially flaked edge. Based on use-wear, in the form of step fracturing and battering, the tool was used as a chopper.

One edge-modified flake was found during auger testing (Auger Test 100, Level 2). The tertiary flake has unifacial use-derived micro-flaking on two edges. The tool is small, measuring $29.36 \mathrm{~mm}$ in length, by $5.77 \mathrm{~mm}$ thick, and $26 \mathrm{~mm}$ wide. The tool exhibited a width to thickness ratio of 4.6. Flake tools such as this represent the use of readily available flake debris, therefore reducing manufacture costs and increasing the likelihood that the tool will be discarded immediately following use. 


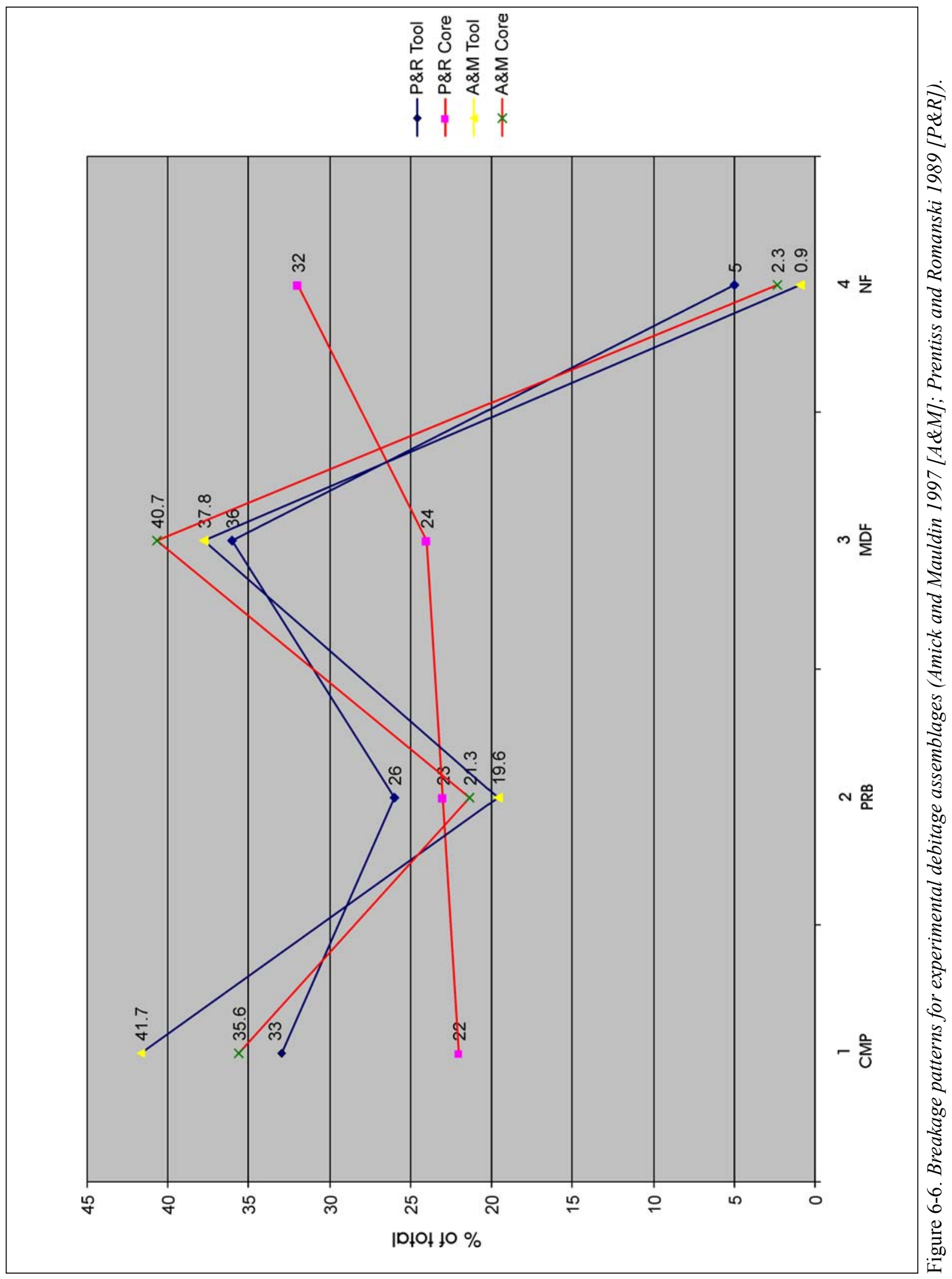




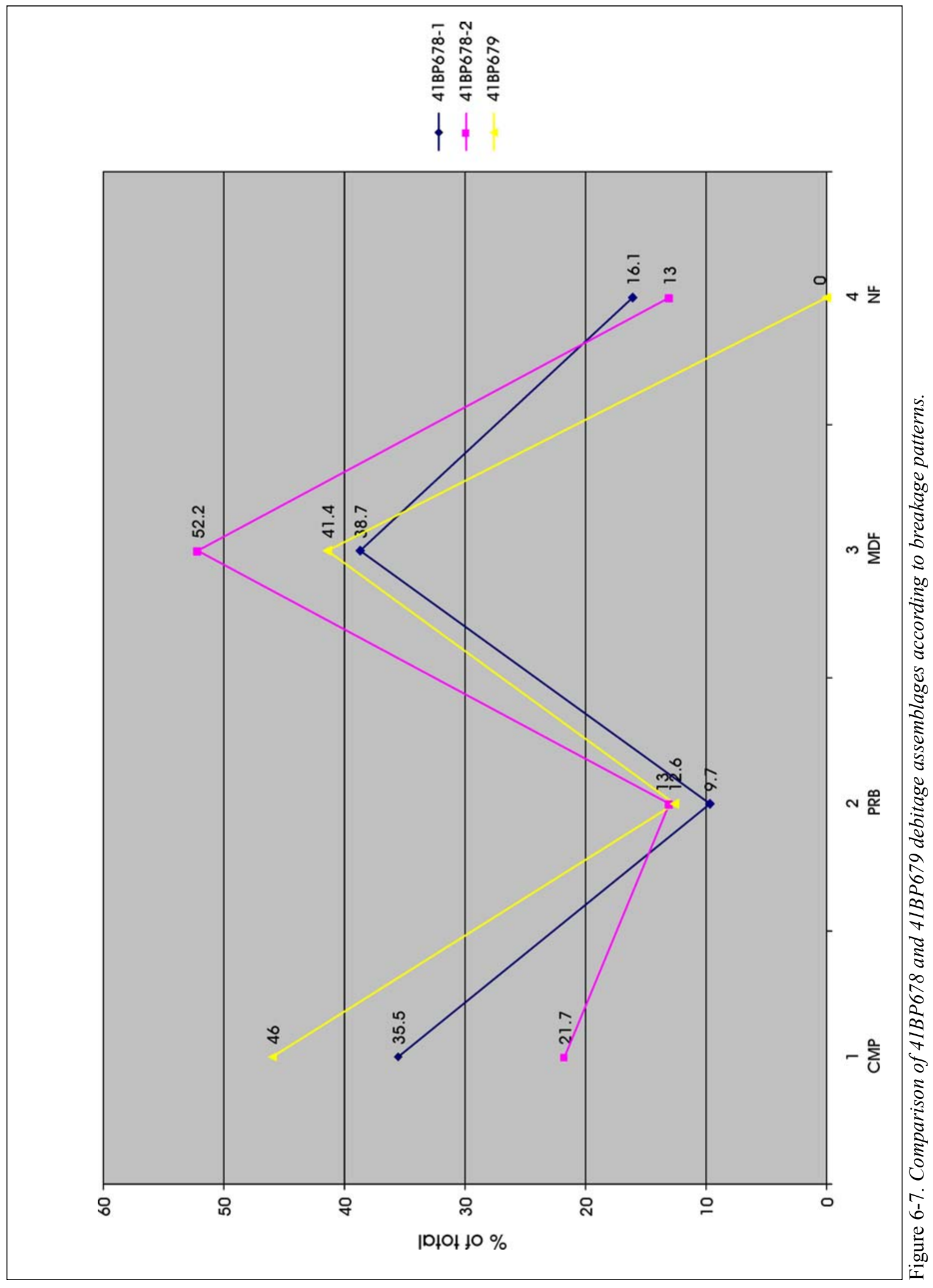




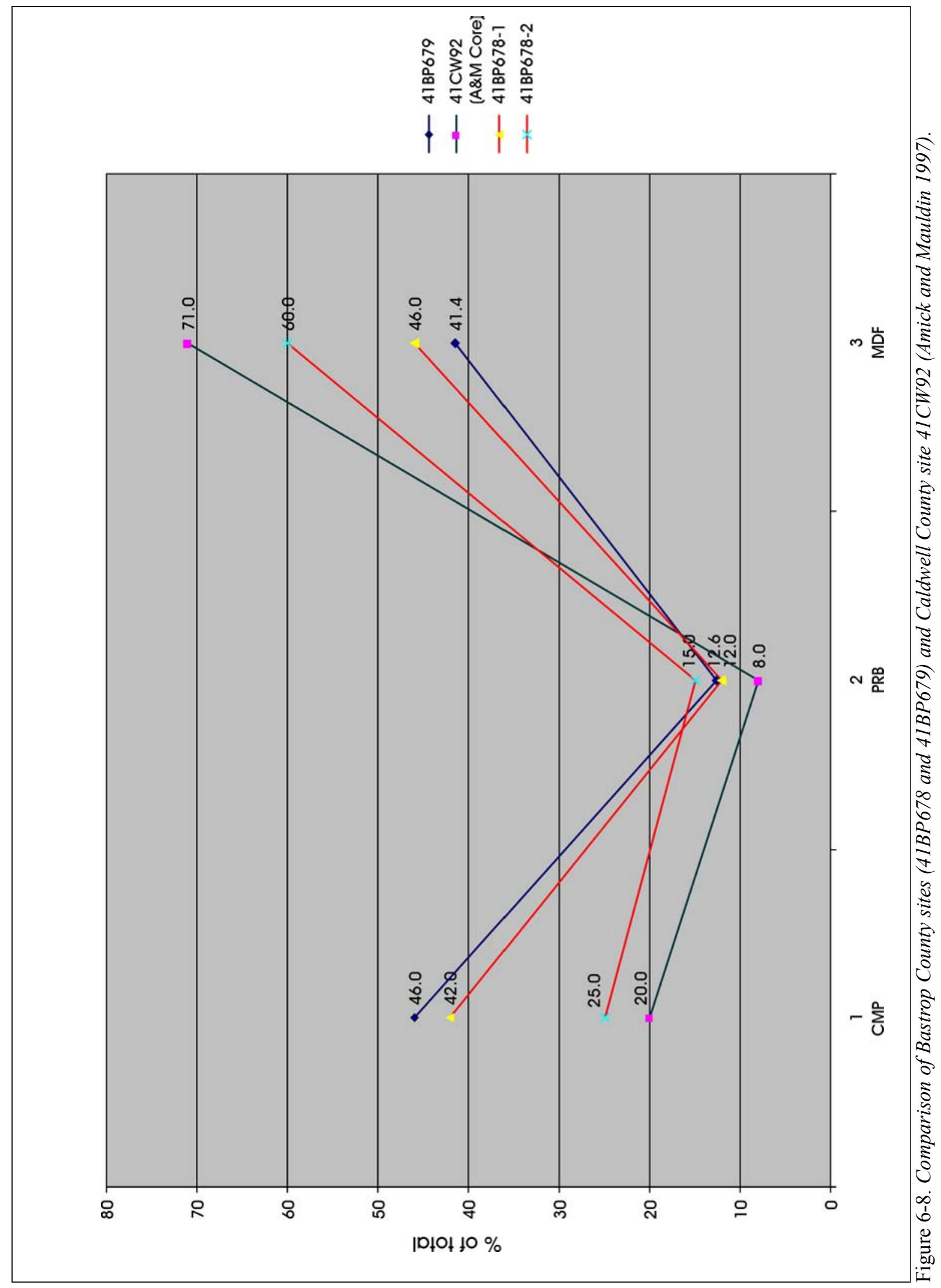


Two bifaces were also recovered from auger tests. The larger biface $(92.6 \mathrm{~mm}$ in length, $28.7 \mathrm{~mm}$ thick, and $65.5 \mathrm{~mm}$ wide), appears to have $25 \%$ cortex still remaining (Figure 6-10). The width to thickness ratio for the tool is 2.26. Use-wear is not apparent on the biface. The second biface is broken. The break fracture appears to be from use, rather than manufacturing. The specimen measures $21.8 \mathrm{~mm}$ long, $8.15 \mathrm{~mm}$ thick and $20 \mathrm{~mm}$ wide, and has a width to thickness ratio of 2.5 . The tool also has evidence of heat spalling.

The cobble tool and larger biface give a good indication of raw material size, though material collected from around the project area (see Chapter 2) is larger and thicker (averaging $17 \mathrm{~cm}$ in length and $5 \mathrm{~cm}$ in thickness). Due to the sample size of lithic tools $(\mathrm{n}=4)$, it is difficult to make any conclusions on site function or use.

\section{FCR and Heat Spalls}

A mixture of FCR and heat spalls were retrieved from the site $(n=40)$. FCR is usually indicative of features, although heat spalls can also derive from natural burning events. No features were revealed during testing and the distribution of burned material was sparse, without any distinct clustering. Although FCR and heat spalls are evident in the upper and lower components, $56 \%$ of the burned rock material is associated with the lower component of the site.

\section{Ceramics}

Seven ceramic sherds were recovered during the testing of 41BP678. All the ceramics were recovered from the upper component, therefore, supporting a Late Prehistoric temporal affiliation. This region of Texas has been associated with the Toyah culture (Johnson 1994; Wade 2003). Prehistoric ceramics associated with the Toyah Phase of the Late Prehistoric are identified as Leon Plain. This ceramic type is usually identified by its bone tempering, tan to orange surfaces, and blackened cores (Johnson 1994; Nickels 2000; Perttula et al. 1995). Surface treatment has been reported mostly as polishing and floating. Assemblages do tend to exhibit some variability when it comes to tempering agents with the evidence of bone and sand (Nickels 2000; Kalter et al. 2005). Many studies tend to focus on whether sand was an intentional tempering agent or naturally occurring in the clays. These questions lead most ceramic analysis on Leon Plain to focus on clay sourcing. Cultural affiliation is typically used to explain the variation in ceramic assemblages (Kalter et al. 2005; Ricklis 1995).

Two ceramic fragments were recovered from TU 1, Level 4. The largest sherd (18 $\mathrm{mm}$ thick) appeared to be a handle fragment with bone temper and a slight polishing on the exterior surface. The core of the fragment was black in color, indicating a low firing temperature and/or a reduced firing atmosphere. The exterior of the sherd is orange, a color that usually derives from an oxidized firing environment. The second sherd was smaller and appeared to have characteristics similar to the larger sherd.

There were five ceramics sherds present in TU 4, Level 2. The identified inclusions (or perhaps temper) appear to be sand. The core of the larger sherd $(15.20 \mathrm{~mm}$ in length and $6 \mathrm{~mm}$ thick) is blackened. The four smaller sherds $(<10 \mathrm{~mm})$ also contain sand inclusions and have blackened cores. Variation in temper, such as exhibited in the small assemblage, is usually attributed to clay sourcing and/or cultural affiliations (Kalter et al. 2005; Nickels 2000; Ricklis 1995). Rather than affiliating temper types with clay sources and particular cultural traditions, factors such as labor investments for ceramic production and food preparation (dependent on subsistence strategies) should be considered. It seems more probable that these factors may be contributing to the variation in Native American ceramic assemblages.

\section{Conclusions}

This chapter discussed the artifacts from 41BP678. The debitage analysis revealed that the two components are represented by different assemblages. Debitage from 41BP679 represents yet another assemblage that varies from the two components at 41BP678. The small number of Native American ceramics and a small tool assemblage in the Late Prehistoric component suggest perhaps a short-term occupation. It is difficult to interpolate the lower component of the site with the lack of diagnostic materials, although the low density of artifacts implies that it too was used for a short period of time. 


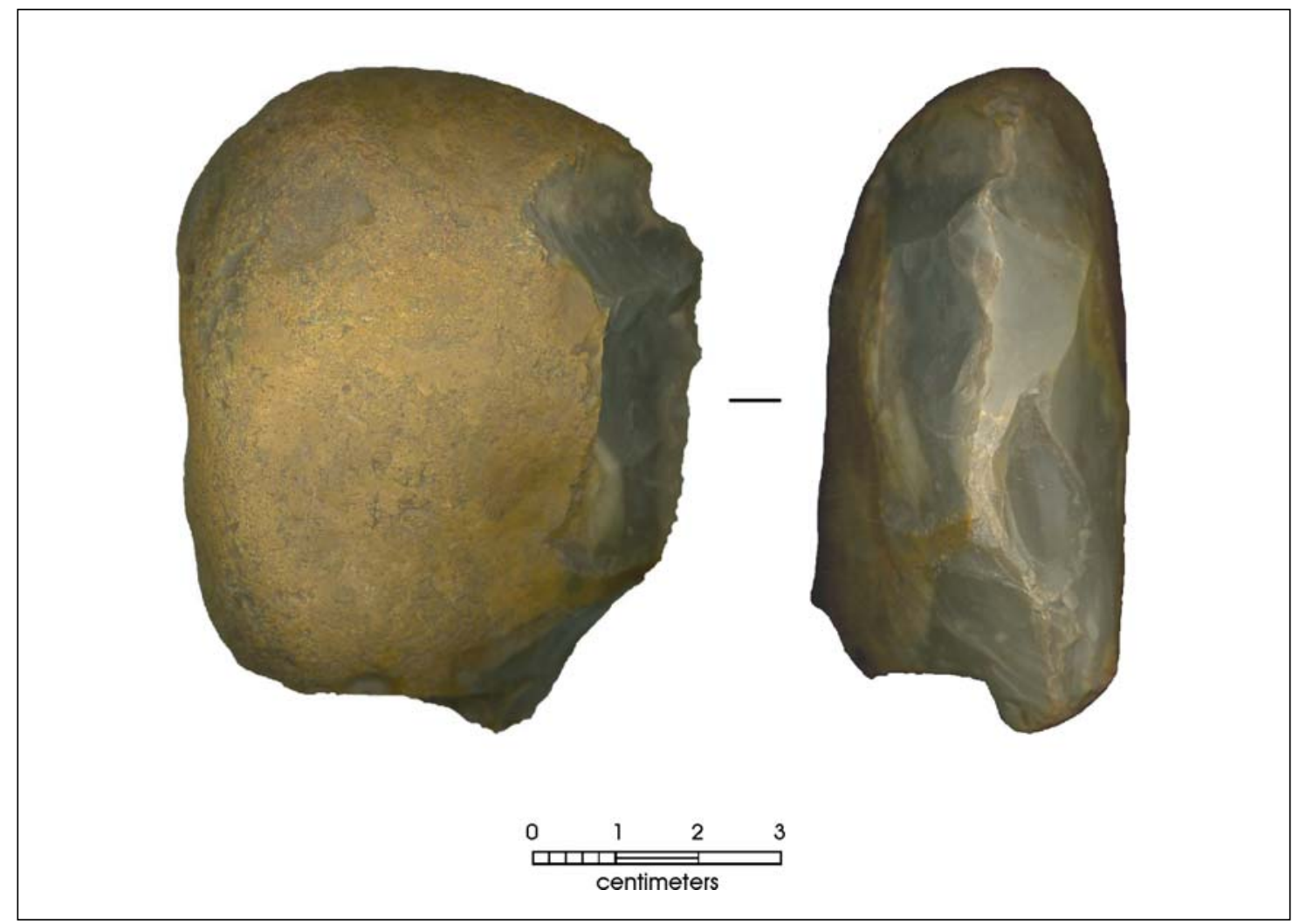

Figure 6-9. Cobble tool (chopper) encountered during auger testing of 41 BP678.

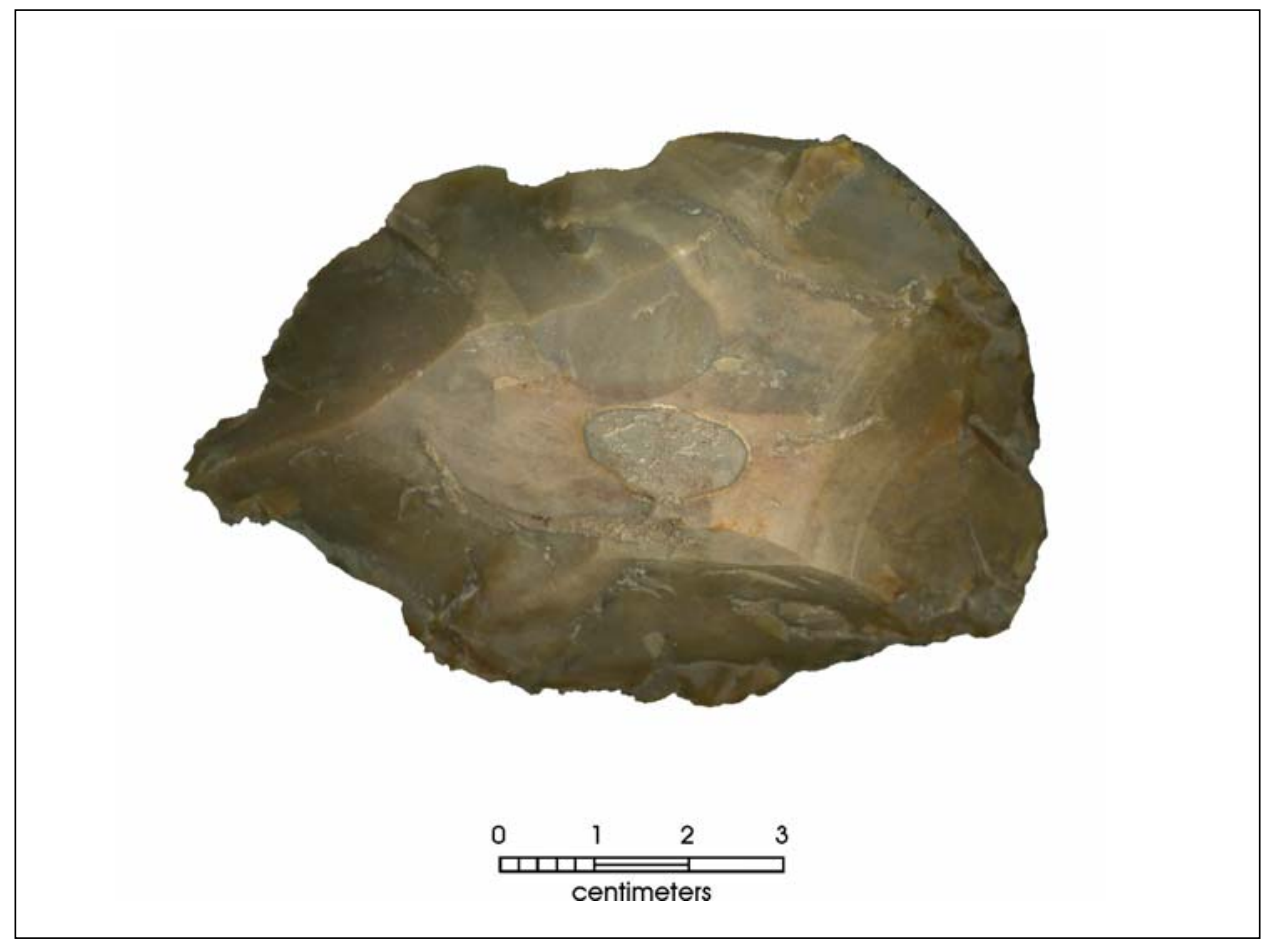

Figure 6-10. Early reduction biface encountered during auger testing of 41 BP678. 



\section{Chapter 7: Conclusions and Recommendations}

\section{Steve A. Tomka and Antonia L. Figueroa}

From April 27 through May 4, 2006 the Center for Archaeological Research at The University of Texas at San Antonio tested site 41BP678 in Bastrop County, Texas. The work was conducted for the City of Bastrop, which will be constructing a water treatment facility within a 26.5 -acre tract that includes 41BP678 and a nearby site, 41BP679 (Munoz 2006). While the 4.5-acre facility is planned primarily to the northwest of the 41BP678 site boundary, the installation of an outfall line, the excavation of a well, and trenching associated with the installation of pipes and utilities leading to and from the well will impact portions of the site. The installation of the outflow pipeline for discharge may extend to a maximum depth of 10 feet in places but it is estimated that the trench will be shallower on 41BP678 due to the sloping terrain crossed by the pipe easement. While excavations associated with the well may extend as deep as 500 feet below the surface, the installation of associated utilities will require a trench no deeper than four feet.

Site 41BP678 is listed as a State Archaeological Landmark. Consequently, the eligibility of the site is not in question. The archaeological work was conducted to determine whether the cultural deposits and materials found in the portions of the site that would be impacted by the planned construction contributed to the eligibility of 41BP678. Secondary goals of the fieldwork were to more accurately determine the northern boundary of the site and establish the ages of the two components identified on this site during the earlier survey (Moses 2004).

Testing of 41BP678 included mechanical auger borings, backhoe trenching and the hand-excavation of four $50-\mathrm{x}-50-\mathrm{cm}$ test units. The testing fieldwork conducted on site was limited to the northern half of the site and in the two linear areas that were to be impacted by the pipeline installations and the excavation for the well. Seventy-nine auger bores were excavated. They were roughly $30 \mathrm{~cm}$ in diameter and extended to a depth of $80 \mathrm{cmbs}$. The borings were excavated in two layers, $0-40 \mathrm{cmbs}$ and $40-80 \mathrm{cmbs}$. The survey-level investigations of the site indicated that cultural materials did not appear to extend below $80 \mathrm{~cm}$ in depth. The main goal of this exploratory technique was to establish the presence/absence of cultural materials, their gross vertical distribution and horizontal patterning. Four backhoe trenches were excavated. They measured approximately $10 \mathrm{~m}$ in length, one meter in width and extended to roughly one meter below surface. We excavated these trenches following the review of the material distributions obtained from the auger units. We placed them in areas of higher material density in the hopes of exposing site stratigraphy in different parts of the site, and to search for features. Secondarily, the backhoe trenches also helped us investigate deposits that fell within the easement of the proposed outfall and utilities lines. Finally, we employed four $50-\mathrm{x}-50-\mathrm{cm}$ test units excavated in $10-\mathrm{cm}$ arbitrary levels to obtain more fine-grained information on the vertical distribution of cultural materials. These units adjoined the backhoe trench walls.

Though the material culture recovered from the site was sparse, excavations revealed two components: an upper component extending from surface to $40 \mathrm{cmbs}$ and a lower component extending from 40 to $80 \mathrm{cmbs}$. The upper component appears to date to the Late Prehistoric period, as indicated by the seven Native ceramic sherds encountered in two of the test units. The temporal association of the deeper deposits is unknown.

Excavations at $41 \mathrm{BP} 678$ produced 54 pieces of debitage from a volume of $5.41 \mathrm{~m}^{3}$ of matrix representing 10 pieces of debitage percubic meter. In addition, four tools including two bifaces, one cobble tool and one edge-modified flake also were recovered from auger testing. Seven ceramic sherds were recovered during the testing. Two of them appear to be sand-tempered or contain sandy inclusions in the paste while the other five are bone-tempered and appear to fit the Leon Plain type commonly associated with Toyah Phase occupations. A mixture of FCR and heat spalls were retrieved from the site $(\mathrm{n}=40)$ in addition to snail shells and few mussel shell umbos. Despite the recovery of FCR and heat spalls, no features were identified during the excavations. The stratigraphy of the deposits appears to be relatively homogenous with a $30-35 \mathrm{~cm}$ thick disturbed zone near the top and $40-60 \mathrm{~cm}$ of silty clay below it with calcium carbonate nodules increasing in frequency in the lower portions of the profile. 
The analysis of a number of attributes on the debitage does suggest some intriguing differences in technological characteristics between the upper and lower components. The upper component appears to be most similar to experimental debitage assemblages derived from tool reduction while the collection of debitage from the lower component seems to be more similar to experimental assemblages produced by core reduction.

The low density of cultural materials, when combined with the absence of features and the turbation of the upper 30 to $35 \mathrm{~cm}$ of the site limits the research potential of the upper Late Prehistoric deposits. While the lower component does not appear to be turbated, artifact densities are low, no features were observed, and we lack temporal affiliation for these deposits. Therefore, CAR argues that the materials recovered from the portion of the site tested during the fieldwork do not contribute to the SAL eligibility of 41BP678. We recommend that the northern portion of the site (Figure 7-1) be cleared for planned construction. As the southern portion of 41BP678 has not been tested, we further recommend that this southern portion remain off limits with regard to any construction activities.

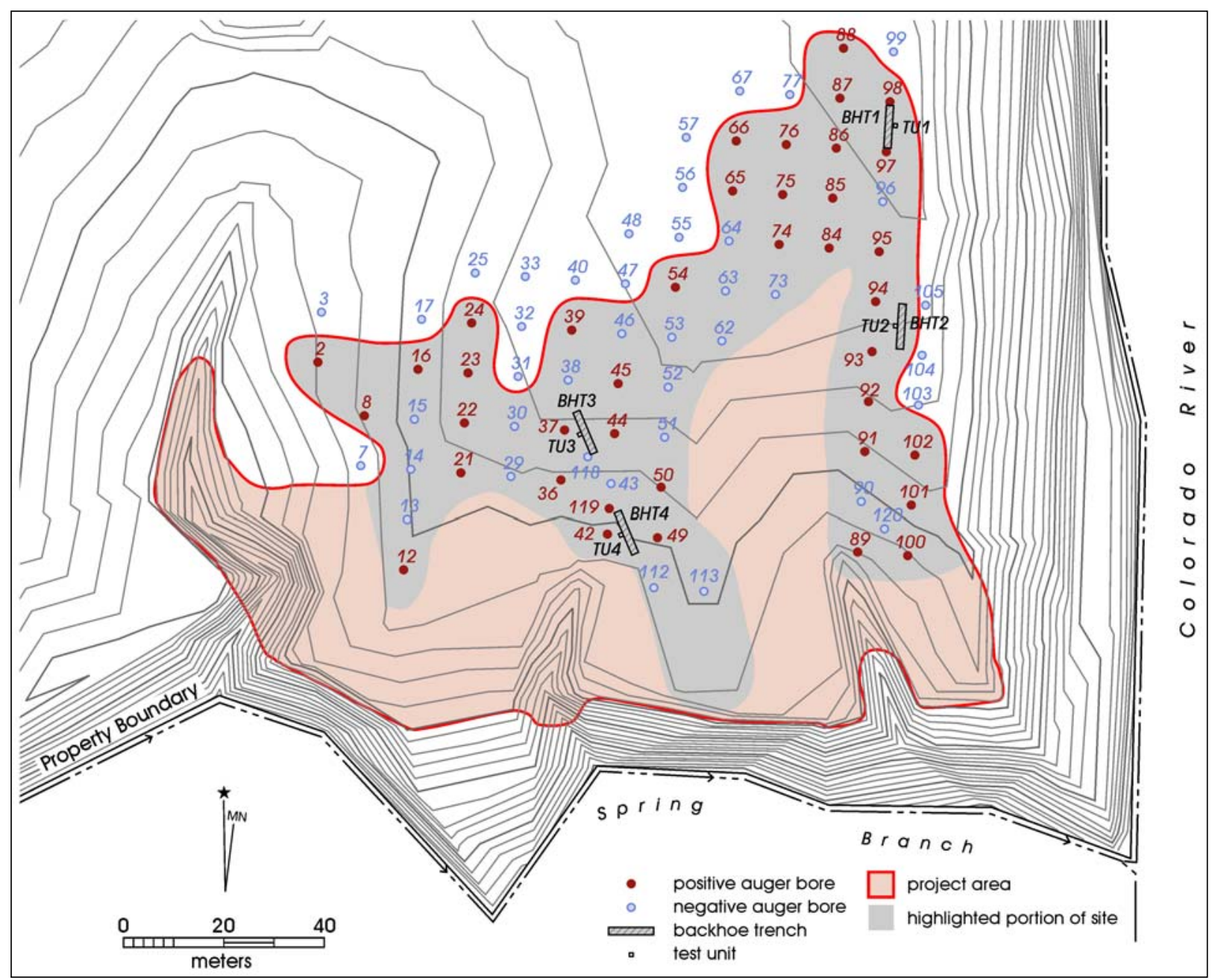

Figure 7-1. Highlighted area showing portion of site $41 B P 678$ not contributing to the eligibility of the site. 


\section{References Cited}

Abbott, J. T.

1994 Geomorphic Context of the Barton Site (41HY202) and the Mustang Branch Site (41HY209). In Archaic and Late Prehistoric Human ecology in the Middle Onion Creek Valley, Hays County, Texas, edited by Robert A. Ricklis and Michael B. Collins, pp. 353-379. Studies in Archeology 19. Texas Archeological Research Laboratory, The University of Texas at Austin.

Amick, D. and R. P. Mauldin

1989 Comments on Sullivan and Rozen's “Debitage Analysis and Archaeological Interpretation.” American Antiquity 54:166-168.

1997 Effects of Raw Material on Flake Breakage Patterns. Lithic Technology 22(1):18-32.

Andrefsky, W., Jr.

1998 Lithics: Macroscopic Approaches to Analysis. University Press, Cambridge.

Antevs, E.

1955 Geologic-Climatic Dating in the West. American Antiquity 20:317-335.

Baker, F. E.

1979 Soil Survey of Bastrop County, Texas. Soil Conservation Service, U.S. Department of Agriculture, Washington, D.C.

Barnes, V. E.

1974 Geologic Atlas of Texas. Austin Sheet. Scale 1:250,000. Bureau of Economic Geology. The University of Texas at Austin.

Bement, L. C.

1989 Excavations at 41BP19: The Kennedy Bluffs Site, Bastrop County, Texas. Texas Archeological Research Laboratory, The University of Texas at Austin. Contract Reports in Archaeology, Report No. 5, Highway Design Division, Texas State Department of Highways and Public Transportation, Austin.

Black, S. L.

1989 Central Texas Plateau Prairie. In From the Gulf Coast to the Rio Grande: Human Adaptation in Central, South and Lower Pecos, Texas, edited by T. R. Hester, S. L. Black, B. G. Steele, B. W. Olive, A. A. Fox, K. J. Reinhard, and L. C. Bement, pp. 17-38. Research Series No. 33. Arkansas Archeological Survey, Fayetteville.

Black, S. L. and D. G. Creel

1997 The Central Texas Burned Rock Midden Reconsidered. In Hot Rock Cooking on the Greater Edwards Plateau: Four Burned Rock Midden Sites in West Central Texas, by Steve Black, Linda W. Ellis, Darrell G. Creel, and Glenn T. Goode, pp. 269-305. Studies in Archeology 2. Texas Archeological Research Laboratory, The University of Texas at Austin.

Blair, W. F.

1950 The Biotic Provinces of Texas. Texas Journal of Science 2(1):93-117. 
Blum, M. D., R. S. Toomey, and S. Valastro, Jr.

1994 Fluvial Response to Late Quaternary Climatic and Environmental Change, Edwards Plateau, Texas. Palaeogeography, Palaeoclimatology, Palaeoecology 108:1-21.

Bousman, B. C.

1994 Central Texas Pollen Record: A Reinterpretion. Current Research in the Pleistocene 11:79-81.

1998 Paleoenvironmental Change in Central Texas: The Palynological Evidence. Plains Anthropologist 43 (164):201-219.

Bryant, V. M., Jr., and R. G. Holloway

1985 A Late-Quaternary Paleoenvironmental Record of Texas: An Overview of the Pollen Evidence. In Pollen Records of Late-Quaternary North American Sediments, edited by V. T. Bryant, Jr., and R. G. Holloway, pp. 39-70. American Association of Stratigraphic Palynologists Foundation, Dallas, Texas.

Collins, M. B.

1995 Forty Years of Archaeology in Texas. Bulletin of the Texas Archeological Society 66:361-400.

1998 Wilson-Leonard: An 11,000-year Archaeological Record of Hunter-Gatherers in Central Texas. Studies in Archaeology 31. Texas Archeological Research Laboratory, The University of Texas at Austin. Archeology Studies Program, Report No. 10. Environmental Affairs Division, Texas Department of Transportation, Austin.

2004 Archeology in Central Texas. In The Prehistory of Texas, edited by Timothy K. Perttula, pp.101-126. Texas A\&M University Press, College Station.

Duke, P. L.

1977 Lake Thunderbird Site (41BP78), Bastrop, Texas. La Tierra 4(3):15-26.

Frederick, C. D., M. D. Glascock, H. Neff, and C. M. Stevenson

1994 Evaluation of Chert Patination as a Dating Technique: A Case Study from Fort Hood, Texas. Mariah Associates, Austin. Research Report No. 32. Archaeological Resource Management Series, United States Army, Fort Hood.

Gadus, F. E., R. C. Fields, and K. W. Kibler

2006 Data Recovery Excavations at the J.B. White Site (41MM341), Miliam County, Texas. Reports of Investigations, No. 145. Prewitt and Associates, Inc., Austin.

Gould, F. W.

1969 Texas Plants: A Checklist and Ecological Summary. Publication MP-585. Texas Agricultural Experiment Station. Texas A\&M University, College Station.

Hall, S. A.

1990 Channel Trenching and Climatic Change in the Southern U.S. Great Plains. Geology 18:342-345.

Hester, T. R.

1995 The Prehistory of South Texas. Bulletin of the Texas Archeological Society 66:427-459. 
Hofman, J. L.

1989 Prehistoric Culture History-Hunters and Gatherers in the Southern Great Plain. In From Clovis to Comanchero: Archeological Overview of the Southern Great Plains, by J. L. Hofman, R. L. Brooks, J. S. Hays, D. W. Owsley, R. L. Jantz, M. K. Marks, and M. H. Manhein, pp. 25-60. Research Series No. 35. Arkansas Archeological Survey, Fayetteville.

Houk, B. A., W. B. Law, and K. A. Miller

2005 Significance Testing at the Troll Site, 41CW92, Caldwell County, Texas. Report No. 2005-137. SWCA Environmental Consultants, Austin.

Hurt, R. D.

1980 Archeological Investigations of Portions of the Middle Concho Valley. Unpublished Master's thesis, Texas Tech University, Lubbock.

Johnson, L.

1994 The Life and Times of Toyah-Culture Folk: The Buckhollow Encampment, Site 41KM16, Kimble County, Texas. Office of the State Archeologist Report 38. Texas Department of Transportation and Texas Historical Commission, Austin.

Johnson, L. and G. T. Goode

1994 A New Try at Dating and Characterizing Holocene Climates, as well as Archaeological Periods, on the Eastern Edwards Plateau. Bulletin of the Texas Archaeological Society 65:1-51.

Kalter, A. J., R. M. Rogers and M. N. Smith

2005 Analysis and Reporting for 41FY135, the Sandbur Site, Fayette County, Texas. Document No. 020388, PBS\&J. Archeological Studies Program Report No. 73, Texas Department of Transportation, Austin.

Kenmotsu, N. D.

1982 Cultural Resource Investigations at the Powel Bend Prospect, Bastrop County, Texas. Research Report No. 84, Texas Archeological Survey, The University of Texas at Austin.

Klinger, T. C., J. W. Smith, D. R. Dickson, A. J. Hawkins, and J. L. Gray, IV

1999 Texas Pipeline 2: Cultural Resource Documentation. Historic Preservation Associates Reports 99-09. Historic Preservation Associates, Fayetteville, Arkansas.

Magne, M. P. R.

1989 Lithic Reduction Stages and Assemblage Formation Processes. In Experiments in Lithic Technology, edited by D. S. Amick and R. P. Mauldin, pp. 15-31. British Archaeological Reports International Series 528, Oxford.

Mahoney, R. B., and S. A. Tomka

2001 National Register Eligibility Testing of 41MM340 and 41MM341, along Little River, Milam County, Texas. Archaeological Survey Report, No. 303. Center for Archaeological Research, The University of Texas at San Antonio. Archeological Studies Program Report No. 30, Environmental Affairs Division, Texas Department of Transportation, Austin. 
Mauldin, R. P.

2006 Appendix D: Stable Carbon and Oxygen Isotopic Variability in Snail Shells from 41MM340 and 41MM341. In Data Recovery Excavations at the J. B. White Site (41MM341), Miliam County, Texas, by E. Frances Gadus, R. C. Fields, and K. W. Kibler. Reports of Investigations, No. 145. Prewitt and Associates, Inc.

Mauldin, R. P., and D. S. Amick

1989 Investigating Patterning from Experimental Bifacial Core Reduction. In Experiments in Lithic Technology, edited by D. S. Amick and R. P. Mauldin, pp. 88-100. British Archaeological Reports International Series 528, Oxford.

Mauldin, R. P., and A. L. Figueroa

2005 Test Excavations and Monitoring at 41BX1598, A Multicomponent Site in San Antonio, Bexar County, Texas. Archaeological Report, No. 360. Center for Archaeological Research, The University of Texas at San Antonio.

Mauldin, R. P., D. L. Nickels, and C. J. Broehm

2003 Archaeological Testing to Determine the National Register Eligibility Status of 18 Prehistoric Sites on Camp Bowie, Brown County, Texas (Volume 1 and Volume 2). Archaeological Survey Report, No. 334. Center for Archaeological Research, The University of Texas at San Antonio.

Meltzer, D. J. and M. R. Bever

1995 Paleoindians of Texas: An Update on the Texas Clovis Fluted Point Survey. Bulletin of the Texas Archeological Society 66:47-81.

Moses, B.

2004 An Archeological Survey of the Proposed Location of the Bastrop City Wastewater Treatment Plant, Bastrop County, Texas. Archaeological Survey Report, No. 353. Center for Archaeological Research, The University of Texas at San Antonio.

Munoz, C. M.

2006 Archaeological Testing at 41BP679, Bastrop County, Texas. Archaeological Report, No. 366. Center for Archaeological Research, The University of Texas at San Antonio.

Nickels, D. L.

2000 The Bisenbach Site (41WN88): A Case Study in Diet Breadth. Unpublished Master's thesis. The University of Texas at San Antonio.

Nickels, D. and R. Mauldin

2001 The Project Environment. In An Archaeological Survey of Twin Buttes Reservoir, Tom Green County, Texas, edited by Raymond P. Mauldin and David L. Nickels, pp. 25-38. Archaeological Survey Report, No. 300. Center for Archaeological Research, The University of Texas at San Antonio.

Nickels, D. L., M. L. Lehman, and C. B. Bousman

2001a Archaeological Evaluation of 39 Category V Sites at Camp Swift, Bastrop County, Texas. Archaeological Studies Report No. 3. Center for Archaeological Studies, Southwest Texas State University, San Marcos, Texas.

Nickels, D., P. McWhorter, and K. Miller

2001b Cultural Chronology and Previous Archaeological Research. In An Archaeological Survey of Twin Buttes Reservoir, Tom Green County, Texas, edited by Raymond P. Mauldin and David L. Nickels, pp. 55-69. Archaeological Survey Report, No. 300. Center for Archaeological Research, The University of Texas at San Antonio. 
Nordt, L. C., T. W. Boutton, J. S. Jacob, and R. Mandel

1994 Late Quaternary Climates of Central Texas Based on the Stable Isoropic Composition of Organic Carbon. Program and Abstracts, 52 ${ }^{\text {nd }}$ Plains Coinference, $65^{\text {th }}$ Annual Meeting of the Texas Archeological Society, Lubbock, Texas.

Perttula, T. K., M. R. Miller, R. A. Ricklis, D. J. Prikryl, and C. Lintz

1995 Prehistoric and Historic Aboriginal Ceramics in Texas. Bulletin of the Texas Archeological Society 66:175-235.

Prentiss, W. C. and E. J. Romanski

1989 Experimental Evaluation of Sullivan and Rozen's Debitage Typology. In Experiments in Lithic Technology, edited by D. S. Amick and Raymond P. Mauldin, pp. 89-99. British Archaeological Reports International Series 528 , Oxford.

Prewitt, E. R.

1981 Culture Chronology in Central Texas. Bulletin of the Texas Archeological Society 52:65-89.

Ricklis, R. A.

1995 The Ceramics of the Toyah Horizon and the Rockport Phase as Indicators of some Basic Sociocultural Patterns. Bulletin of Texas Archaeological Society 66:195-203.

Ricklis, R. A., and M. B. Collins

1994 Human Ecology in the Middle Onion Creek Valley, Hays County, Texas. Vol. 1. Studies in Archeology 19. Texas Archeological Research Laboratory, The University of Texas at Austin.

Robinson, D. G.

1987 Bastrop County Historical Commission Sesquicentennial Project: Cultural Resource Investigations Along the Colorado River, Bastrop County, Texas. Archeology Series 2. Texas Archeological Survey, The University of Texas at Austin.

Robinson, D. G., T. M. Meade, L. Haslouer, L. Gassaway, and D. Kay

2001 An Archaeological Inventory at Camp Swift, Bastrop County, Texas, edited by Barbara A. Meissner. Archaeological Survey Report, No. 316. Center for Archaeological Research, The University of Texas at San Antonio.

Schmidt, J. S., and M. E, Cruse

1995 Cultural Resource Survey, Camp Swift, Bastrop County, Texas. Espey, Huston \& Associates, Inc., Austin.

Skelton, D., and M. D. Freeman

1977 Cultural Resource Inventory and Assessment at Camp Swift, Texas. Research Report No. 72. Texas Archeological Survey, The University of Texas at Austin.

Story, D.A.

1985 Adaptive Strategies of Archaic Cultures of the West Gulf Coastal Plain. In Prehistoric Food Production in North America, edited by R. I. Ford, pp. 19-56. Anthropological Papers No. 75. Museum of Anthropology, University of Michigan, Ann Arbor.

Sullivan, A. P., III and K. Rozen

1985 Debitage Analysis and Archaeological Intrepretation. American Antiquity 50(4):755-779. 
Tankersley, K. B., and B. L. Isaac

1990 Early Paleoindian Economies of North America. JAI Press, Greenwich, Connecticut.

Texas Historical Commission (THC)

2006 Texas Archeological Sites Atlas. Electronic database, <http://pedernales.thc.state.tx.us/>, accessed July, 2006.

Toomey, R. S.

1993 Late Pleistoncene and Holocene Faunal and Environmental Changes at Hall's Cave, Kerr, County, Texas. UMI Disseration Services, The University of Texas at Austin.

Toomey, R. S., M. D. Blum, and S. Valastro, Jr.

1993 Late Quaternary Climates and Environments of the Edwards Plateau, Texas. Global and Planetary Change 7:299-320.

Toomey, R. S., and T. W. Stafford, Jr.

1994 Paleoenvironmental and Radiocarbon Study of the Deposits from Hall's Cave, Kerr County, Texas. Program and Abstracts, 52nd Plains Conference, 65th Annual Meeting of the Texas Archeological Society, Lubbock, Texas.

Turner, E. S., and T. R. Hester

1998 A Field Guide to Stone Artifacts of Texas Indians. Third Edition. Gulf Publishing Co., Houston.

Waters, M. R.

1992 Principles of Geoarchaeology: A North American Perspective. The University of Arizona Press, Tucson.

Wade, $\mathrm{M}$.

2003 The Native Americans of the Texas Edwards Plateau, 1582-1799. University of Texas Press, Austin.

Weir, F. A.

1976 The Central Texas Archaic. Unpublished Ph.D. dissertation. Department of Anthropology, Washington State University, Pullman.

Wilson, A. M.

1930 Observations of Indian Life on the Colorado River. Unpublished manuscript on file, Texas Archeological Research Laboratory, The University of Texas at Austin. 